\title{
Molecular and cellular Mechanisms controlling Primordial Germ Cell Migration in Zebrafish
}

\author{
Dissertation \\ submitted \\ at the Georg August University Göttingen, \\ Faculty of Biology \\ for the degree "Doctor of Philosophy (PhD)" \\ in the Molecular Biology Program
}

by

Heiko Blaser

born in

Winterthur, Switzerland 
Referent 1:

Referent 2:

Prof. Michael Kessel

Max-Planck-Institute for biophysical Chemistry Department of Molecular Cell Biology

Am Fassberg 11

37077 Göttingen

Germany 
To my lovely wife Katya and my Family in Switzerland and Mexico. 
Life is like riding a bicycle.

To keep your balance you must keep moving.

Albert Einstein 


\section{$\underline{\text { Affidavit }}$}

I affirm that the thesis "Molecular and cellular Mechanisms controlling Primordial Germ Cell Migration in Zebrafish" has been written independently and with no other sources and aids.

Göttingen, 28.03.2006

Signature: $\underline{\text { Heiko Blaser }}$ 


\section{Table of Contents}

ABBREVIATIONS IX

1 ABSTRACT 1

$\underline{2}$ INTRODUCTION 2

\subsection{GERM CELLS}

$\underline{2.2}$ GERM CELL SPECIFICATION AND DEVELOPMENT

$\underline{2.3}$ CELL MIGRATION

$\underline{2.4}$ EPITHELIAL-MESENCHYMAL TRANSITION (EMT)

$\underline{2.5}$ PRIMORDIAL GERM CELL MIGRATION

$\underline{2.6}$ AIM OF THE THESIS

3.1 THE ASKOPOS GENE IS EXPRESSED IN THE ZEBRAFISH GERMLINE AND ENCODES A NUCLEAR PROTEIN

3.2 ALTERATIONS IN THE LEVEL OF KOP ACTIVITY

3.3 EMPLOYING THE KOP PROMOTER TO ESTABLISH A TRANSGENIC FISH LINE EXPRESSING EGFP-F DURING EARLY PGC DEVELOPMENT $\quad 18$

3.4 EARLY EGFP EXPRESSION IN THE PGCS

$\underline{3.5}$ THE ONSET OF PGC MIGRATION IN ZEBRAFISH 20

3.6 DE NOVO TRANSCRIPTION IN THE ZYGOTE AND DEAD END FUNCTION ARE ESSENTIAL FOR THE CELLULAR MATURATION OF PGC

3.7 $\alpha$-AMANITIN AND $D N D$-MO TREATED PGCS UNDERGO CASPASE INDEPENDENT CELL DEATH DURING ADVANCED STAGES OF EMBRYONIC DEVELOPMENT

3.8 THE LEVEL OF MEMBRANAL E-CADHERIN IS MODULATED DURING EARLY PGC DEVELOPMENT

3.9 ACQUISITION OF PGC RESPONSIVENESS TO SDF-1A REPRESENTS A CELLULAR DIFFERENTIATION STEP THAT IS TEMPORALLY DISTINCT FROM THEIR SPECIFICATION.

3.10 PGCS EXHIBIT INCREASED CALCIUM LEVELS IN THEIR PROTRUSIONS, AN INCREASE THAT DEPENDS ON CXCR4B SIGNALLING.

3.11 ALTERATION OF CALCIUM LEVELS IN PGCS AFFECT THEIR MIGRATION BEHAVIOUR.

3.12 STIM1 TRIGGERED STORE-OPERATED CA ${ }^{2+}$ INFLUX PROMOTES PROTRUSIVE $\begin{array}{ll}\text { ACTIVITY IN PGCS } & 37\end{array}$

3.13 MLCK LOCALIZED TO THE LEADING EDGE OF PGCS ACTIVATES ITS DOWNSTREAM EFFECTOR MLC.

3.14 REGULATED MLCK AND DAPK ACTIVITY IS CRUCIAL FOR NORMAL PGC MIGRATION.

4.1 Cellular Mechanisms OF PGC DifFERENTIATION

$\underline{4.2}$ MOLECULAR MECHANISMS CONTROLLING PGC DIRECTIONAL MIGRATION 48 
6.1 BACTERIA STRAINS
CHEMICALS

6.2 CHEMICALS

$\frac{6.3}{6.4}$ Plasmids/CONSTRUCTS

6.4 ANTISENSE PROBES FOR INSITU HYBRIDIZATION

$\frac{6.5}{6.6}$ MORPHOLINO ANTISENSE OLIGO NUCLEOTIDES

$\frac{6.6}{6.7}$ ANTIBODIES 58

$\frac{6.7}{6.8} \underline{\text { KITS }}$

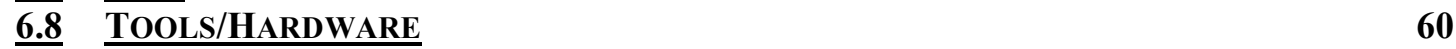

6.9 SOFTWARE

$\frac{6.10}{6.10}$ MOLECULAR BIOLOGY - GENERAL PROTOCOLS

6.10 .1 RNA EXTRACTION AND CDNA SYNTHESIS

6.10.2 POLYMERASE CHAIN REACTION (PCR) 63

$\begin{array}{lll}6.10 .3 & \text { DNA SEPARATION ON AGAROSE GELS } & 64\end{array}$

6.10.4 DNA EXTRACTION FROM AGAROSE GELS $\quad 65$

6.10.5 ENZYMATIC DNA DIGESTIONS AND MODIFICATIONS FOR CLONING PURPOSES 66

6.10.6 PURIFICATION OF LINEARIZED DNA OR PCR PRODUCTS 68

$\begin{array}{lll}6.10 .7 & \text { DNA LIGATION REACTION } & 69\end{array}$

6.10.8 COMPETENT CELLS 69

6.10.9 DNA TRANSFORMATION INTO BACTERIA STRAINS (ELECTRO-COMPETENT CELLS) 70

6.10.10 BACTERIA MINI-CULTURE AND PLASMID DNA ISOLATION 70

6.10.11 ULTRAPURE DNA FOR TRANSGENESIS

6.10.12 DIAGNOSTIC RESTRICTION DIGEST TO VERIFY PLASMID DNA 74

6.10.13 SEQUENCING OF PLASMID DNA 74

6.10.14 SENSE- AND ANTI-SENSE RNA PRODUCTION 74

6.11 ZEBRAFISH - EXPERIMENTAL ANIMAL MODEL

6.11 .1 ZEBRAFISH STRAIN AND FISH MAINTENANCE

6.11.2 INJECTION OF SENSE RNA, DYES AND DRUGS INTO THE ZEBRAFISH EMBRYO 78

6.11.3 FIXATION OF EMBRYOS 82

6.11.4 IN SITU HYBRIDIZATION OF WHOLE MOUNT ZEBRAFISH EMBRYOS 83

6.11.5 IMMUNOHISTOCHEMISTRY OF WHOLE MOUNT ZEBRAFISH EMBRYOS 90

$\begin{array}{ll}\text { 6.11.6 FLUORESCENT LIVE IMAGING } & 91\end{array}$

6.11.7 DATA PROCESSING AND ANALYSIS 91

6.12 DETAILED DESCRIPTION OF ADAPTED EXPERIMENTS PERFORMED FOR THIS WORK

6.12.1 IDENTIFICATION OF THE ASKOPOS (KOP) GENE 92

6.12.2 ALTERATION OF KOP ACTIVITY BY RNA INJECTIONS 92

6.12.3 KOP SUBCELLULAR LOCALIZATION AND KOP MORPHOLINO ACTIVITY 93

6.12.4 KOP PROMOTER CLONING 93

6.12.5 CLONING OF KOP-EGFP-F-NOS1-3'UTR CONSTRUCT AND GENERATION OF
TRANSGENIC FISH

6.12.6 CONSTRUCTS FOR RNA EXPRESSION, KNOCKDOWN AND DRUG EXPERIMENTS 94

6.12.7 FLUORESCENCE MICROSCOPY AND IMAGING OF LIVE CELLS 94

6.12.8 CELL TRANSPLANTATION 95

6.12.9 IMMUNOHISTOCHEMISTRY OF E-CADHERIN 95

6.12.10 IN VIVO STAINING OF ACTIVATED CASPASES 96

$\begin{array}{ll}\text { 6.12.11 CONFOCAL-DATA ANALYSIS } & 97\end{array}$

6.12.12 WHOLE-MOUNT IN SITU HYBRIDIZATION

6.12.13 CONSTRUCTS FOR RNA EXPRESSION TO LABEL PGCS 97

6.12.14 ALTERATION OF MLCK AND DAPK ACTIVITY BY RNA INJECTIONS 98

6.12.15 MLCK SUBCELLULAR LOCALIZATION 98

6.12.16 MYOSIN LIGHT CHAIN PHOSPHORYLATION MEASUREMENTS 99

6.12.17 MEASUREMENT OF CALCIUM LEVELS IN PGCS 99 
6.12.18 ALTERATION OF CALCIUM BY RNA AND MORPHOLINO INJECTIONS 100

6.12.19 FLUORESCENCE STEREO-MICROSCOPY AND CONFOCAL IMAGING OF LIVE CELLS 101

$\underline{7} \quad \underline{\text { LIST OF FIGURES }} \quad 102$

$\underline{8} \quad$ REFERENCES $\quad 103$

9 ACKNOWLEDGEMENTS $\quad 116$

10 LIST OF PUBLICATIONS 118

$\underline{11}$ CURRICULUM VITAE 119 


\section{Abbreviations}

\begin{tabular}{|c|c|}
\hline $\mathrm{AB}$ & antibody \\
\hline bp & base pair \\
\hline BSA & bovine serum albumin \\
\hline cDNA & complementary DNA \\
\hline $\mathrm{Da}$ & Dalton \\
\hline DNA & deoxyribonucleic acid \\
\hline dpf & days post fertilization \\
\hline $\mathrm{dtt}$ & diphtheria toxin \\
\hline E. coli & Escherichia coli \\
\hline EDTA & ethylendiamine tetraacetate \\
\hline EGFP & enhanced green fluorescent protein \\
\hline GFP & green fluorescent protein \\
\hline hpf & hours post fertilization \\
\hline $\operatorname{IgG}$ & immunoglobulin $\mathrm{G}$ \\
\hline $\mathrm{kbp}$ & kilo base pair \\
\hline $\mathrm{MO}$ & morpholino antisense oligonucleotide \\
\hline mRNA & messenger RNA \\
\hline $\mathrm{nt}$ & nucleotide \\
\hline $\mathrm{o} / \mathrm{n}$ & over night \\
\hline ORF & open reading frame \\
\hline PBS & phosphate buffered saline \\
\hline PBT & phosphate buffered saline containing Tween 20 \\
\hline PCR & polymerase chain reaction \\
\hline PGC & primordial germ cell \\
\hline RNA & ribonucleic acid \\
\hline $\mathrm{rpm}$ & revolutions per minute \\
\hline RT & room temperature \\
\hline RT-PCR & reverse transcription polymerase chain reaction \\
\hline wt & wild-type \\
\hline
\end{tabular}




\section{$1 \quad$ Abstract}

In zebrafish, primordial germ cells (PGCs) are specified early in development then migrate to the area where the gonad will form and differentiate into gametes (eggs and sperm). The chemokine SDF-1 (stromal cell derived factor 1), which is expressed by mesodermal somatic cells, is the guidance cue for the migrating germ cells that express the corresponding receptor CXCR4b.

Here we describe the cloning of the regulatory upstream region of the askopos gene, fusing it to a reporter gene and to RNA elements directing stabilization and translation to the PGCs. Generating transgenic fish for this construct allowed us to monitor PGC development in live zebrafish embryos starting from the earliest stages of their development. This analysis revealed distinct phases in early PGC development. During the last phase, a transition into a 'migratory stage' occurs as PGCs become responsive to directional cues provided by somatic cells secreting the chemokine SDF-1a. Furthermore, the transition to this stage is accompanied by a reduction in E-cadherin levels and depends on the function of the RNA binding protein Dead end as well as on de novo transcription in the zygote.

Following the acquisition of motility the PGCs respond immediately to SDF-1a by active migration. In an effort to understand how the guidance signal is translated into directed migration we observed higher levels of $\left[\mathrm{Ca}^{2+}\right]_{\mathrm{i}}$ in the leading edge of directionally migrating PGCs. Artificial manipulations of $\left[\mathrm{Ca}^{2+}\right]_{\mathrm{i}}$ distribution lead to severe problems in germ cell polarity and migration. Such manipulated germ cells exhibit unusual protrusive activity that affects the speed of migration and result in arrival of the cells to ectopic locations within the embryo. To determine the molecular cascade downstream of $\mathrm{Ca}^{2+}$ we have analyzed the role of myosin regulatory light chain kinase (MLCK) in the process. We found that MLCK was localized to the leading edge of PGCs and its activity is important for the spatial and temporal control of protrusion extensions. Indeed, expressing activated or dominant negative forms of MLCK results in aberrant cell polarity, abnormal protrusive behaviour and drastic increase in 'tumbling'-duration. Consistently, we could observe that the myosin regulatory light chain (MLC), is primarily activated in the leading edge of migrating PGCs. In conclusion, the increased calcium levels in the leading edge of migrating germ cells might be important to regulate MLCK activity that triggers actomyosin contraction thus promoting front protrusions to allow persistent migration. 


\section{$\underline{2 \quad \text { Introduction }}$}

\section{$\underline{2.1 \quad \text { Germ Cells }}$}

In sexually reproducing organisms, two gametes (egg and sperm) fuse to initiate the new cycle of life for the next generation. Primordial germ cells (PGCs), the progenitors of the gametes are specified early in development and typically migrate from their specification site to the gonad, the site where they undergo final differentiation (Molyneaux and Wylie, 2004; Raz, 2004; Santos and Lehmann, 2004; Starz-Gaiano and Lehmann, 2001). These features of the germ cells make them an attractive model system for studying aspects of cell specification, differentiation and migration. Of particular relevance for this thesis, germ cells serve as an excellent model for studying long-range directional cell migration.

\section{$\underline{2.2 \quad \text { Germ Cell specification and development }}$}

PGCs are specified very early in development either by the inheritance of maternally supplied RNAs and proteins, collectively called germ plasm, or by inductive signals provided by cells in close proximity surrounding the presumptive primordial germ cells.

The germline in Drosophila, C. elegans, Xenopus, Chick and Zebrafish (Danio rerio) is specified through the inheritance of maternally provided determinants (Hashimoto et al.; Houston and King, 2000; Knaut et al., 2000; Yoon et al., 1997). The localization of RNA molecules to the germ plasm depends on cis-acting RNA elements that reside within the 3' untranslated region (UTR) as shown for the RNA of vasa (Knaut et al., 2002). In addition to the enrichment of specific RNA molecules in the germ plasm, these RNAs are differentially stabilized and translated in PGCs and somatic cells (Köprunner et al., 2001; Wolke et al., 2002). Together, these posttranscriptional mechanisms originally identified in C. elegans and Drosophila (Gavis and Lehmann, 1994; Hay et al., 1988; Lasko and Ashburner, 1988; Seydoux, 1996; Seydoux and Fire, 1994), led to the establishment of a distinct repertoire of proteins expressed in germ cells. Vasa, an RNA helicase of the DEAD-BOX family, was the first gene discovered to be expressed and stabilized in zebrafish PGCs from the 
earliest time point of specification (Yoon et al., 1997). Subsequently, the nanos-1 (Köprunner et al., 2001; Lehmann and Nusslein-Volhard, 1991; Tsuda et al., 2003; Wang and Lehmann, 1991) and dead-end genes were identified and found to be specifically expressed by germ cells in different organisms (Horvay et al., 2006; Weidinger et al., 2003; Youngren et al., 2005). Together, these markers allowed for the first time to describe the expression and localization of the germ plasm and its subsequent stabilization in the PGCs, seen as an electron dense structure (germ granules), during the development of the zebrafish.

Initially, vasa RNA is localized to the cleavage furrows in the 2- and 4-cell stage zebrafish embryo and is eventually inherited by 4 blastomeres that are at four distinct positions in the embryo (Yoon et al., 1997). These four blastomeres divide asymmetrically so that only one of the two cells inherits the germ plasm (Knaut et al., 2000). After this phase, symmetrical cell divisions take place leading to a net increase in PGC number (Knaut et al., 2000).

Germ cell specification in mammals and Urodele amphibians occurs via a different mechanism, which relies on inductive signals (in the form of molecules of the BMP family) rather than from inheriting cytoplasmic determinants (reviewed in Goto et al., 1999; McLaren, 1999; Wylie, 1999). This induction results in an assortment of genes de novo transcribed and expressed by the presumptive PGCs which clearly discriminates them from the surrounding tissue expressing somatic markers (Ohinata et al., 2005; Saitou et al., 2002; Tanaka et al., 2005).

\section{$\underline{2.3} \quad$ Cell migration}

Many biological processes (e.g. embryogenesis, organogenesis etc) rely on the proper migration of different cell types, which have to respond to specific attractive and repulsive signals provided by their cellular environment. The investigation of mechanisms governing motility and directional migration of cells will shed light into important developmental processes in different kinds of organisms.

Numerous studies highlighted the importance of G-protein coupled 7transmembrane domain receptors (GPCR; e.g. CXCR4) in the guidance of migrating cells (Balkwill, 2004; Cockcroft, 1992; Dormann and Weijer, 2003; Oppermann, 2004). For example, the CXCR4 receptor and its ligand the chemokine SDF-1 have 
been shown to be involved in guiding the migration of numerous cell types (Ganju et al., 1998; Kucia et al., 2004; Petit et al., 2002; Vicente-Manzanares et al., 1998; Xiang et al., 2002; Zhu et al., 2002; Chalasani et al., 2003; Arakawa et al., 2003; Lu et al., 2001; Xiang et al., 2002). Importantly, SDF-1 triggers several events downstream of CXCR4 such as Gai activation, calcium mobilization as well as activation of the JAK/STAT pathway. The importance of the second messenger calcium for migration, was shown by the inhibition of the JANUS kinase (JAK), which completely abrogated SDF-1 induced calcium mobilization and subsequently abolished cell migration (VilaCoro et al., 1999).

An important role for calcium in cell migration was also identified in the amoeba Dictyostelium discoideum. The major guidance cue of $D$. discoideum, cAMP, also induced intracellular elevations of calcium. The elimination of these calcium transients by $\mathrm{Ca}^{2+}$-buffers showed the significance of this ion, as such cells exhibited severe migration and chemotaxis defects (Schaloske et al., 2005; Sonnemann et al., 1998; Unterweger and Schlatterer, 1995; Yumura et al., 1996).

Another extensively studied model-system is the axonal growth cone extension and path finding of different neuronal precursor cells (reviewed in Chilton, 2006). Recent studies of axon guidance have shown that extracellular gradients of chemoattractants (e.g. netrin-1, SDF-1) can induce turning of the growth cone that is sensitive to the level of calcium (Li et al., 2005). Remarkably, the increase of calcium in the growth cone was polarized. Higher calcium levels were observed on the side facing higher concentration of the guidance cue in the case of netrin-1 and myelinassociated glycoprotein (MAG) (serving as attractive and repulsive cues respectively) (reviewed in Gomez and Zheng, 2006; Henley and Poo, 2004).

Previous studies revealed a number of proteins involved in growth cone motility and guidance, which are regulated directly or indirectly by calcium or by its effector proteins (e.g. calpains, protein kinase $\mathrm{C}_{\text {or }} \mathrm{Ca}^{2+} /$ calmodulin-dependent kinase II). The inhibition of $\mathrm{Ca}^{2+} /$ calmodulin-dependent kinase II in cultured Xenopus spinal neurons abolished attractive turning to the guidance cue acetylcholine (ACh). This result demonstrated that the $\mathrm{Ca}^{2+} /$ calmodulin-dependent kinase II is important for growth cone guidance and that other kinases that control cytoskeleton modulations might play a role in cell motility and guidance as well. Indeed, the $\mathrm{Ca}^{2+} /$ calmodulin dependent myosin light chain kinase (MLCK) stimulates actomyosin-based contraction through the phosphorylation of its substrate, the myosin regulatory light 
chain (MRLC). In support of the importance of this protein, the consequence of local MLCK inhibition at a one side of the growth cone was repulsive turning counteracting the attraction from the chemokine gradient. Calcium signalling is also involved in pathological conditions. For example, the calcium dependent protease, calpain, contributes to the remodelling of cytoskeletal structures, which promotes cell migration. Tumors that have metastasized (e.g. carcinomas and breast cancer cells) show a significantly increased expression profile of calpain-1 in comparison to tumors that had not metastasized. This indicates a direct relation between calpain-1 expression levels and the developmental stage of the tumor in respect of its invasive ability (reviewed in Carragher and Frame, 2002).

Another aspect controlling cell migration is the physical interaction of cells with other cells in their environment. Indeed, it was shown that E-cadherin protein level and distribution plays a crucial role in Drosophila border cell migration. The border cells need to be able to downregulate E-cadherin protein levels on the plasma membrane in order to migrate properly on the nurse cells (reviewed in Montell, 2003). Similar results have been obtained from studies of metastatic cancer cell lines, which gain motility by reducing E-cadherin protein on their membrane. Investigating the molecular mechanisms that regulate E-cadherin protein expression, localization and distribution might significantly help in understanding the migratory behaviour of cancer cells (reviewed in Naora and Montell, 2005).

\section{$\underline{2.4 \quad \text { Epithelial-Mesenchymal Transition (EMT) }}$}

Epithelial cells show a specific basolateral orientation in respect to their neighbours. These cells display strong cell-cell adhesions mediated by cadherins and integrins and other molecules involved in cell junctions. Epithelial cells are motile but can only move within the epithelial layer therefore changing their closest neighbouring cells. Nevertheless, these cells cannot freely move away from the epithelial layer and will not give up their attachment sites. When epithelial cells undergo dynamic remodelling of the cytoskeleton, they lose firm cell-cell adhesions and change their polarity to achieve a mesenchymal morphology. This progression from a non-motile to motile cell behaviour is commonly termed epithelial-mesenchymal transition (EMT). 
Mesenchymal cells do not necessarily change their fate but they do not cluster in organized cell layers and migrate more freely among other cells.

EMT is an essential process during embryogenesis (e.g in neural crest development (Halloran and Berndt, 2003; Savagner, 2001) and border cells (Rørth, 2002; Starz-Gaiano and Montell, 2004)) and was also shown to be involved in diseases in the adult organism. Molecules involved in EMT are fibroblast growth factors (FGF), proteins from the snail family and E-cadherin. Important changes in the gene expression profile during EMT mainly affect E-cadherin, N-cadherin and the intermediate filament vimentin. Downregulation of E-cadherin results in several cellular effects, which all facilitate the loss of E-cadherin-dependent intercellular complexes and the activation of small GTPases (e.g. Rap1, RhoA and Rac1) that will accomplish the remodeling of cytoskeletal structures allowing the completion of EMT. Recent observations indicate that EMT plays a role in tumor progression, which results in alteration of adhesiveness and promotion of motility thereby allowing tumor cell invasion into foreign tissues. Indeed, mutations in the E-cadherin gene or in E-cadherin regulators were suggested to promote EMT of tumor cells facilitating metastasis (reviewed in Kopfstein and Christofori, 2006; Thiery, 2002; Thiery and Sleeman, 2006).

\section{$\underline{2.5} \quad$ Primordial Germ Cell migration}

In most sexually reproducing organisms, primordial germ cells (PGCs) are specified early in development at a position distinct from that where the gonad develops. From this position the PGCs are guided in response to attractive and repulsive cues provided by the somatic tissues along their migratory route. Below, a brief description of PGC migration in different organisms is provided to get an overview of molecular relationships.

\section{Drosophila}

PGCs in Drosophila are specified at the posterior pole of the embryo (Schejter and Wieschaus, 1993)). During gastrulation, the invagination of the posterior midgut primodia extends the germ band and the PGCs are passively carried into the forming posterior midgut. Subsequently, the germ cells exit the lumen of the gut by 
transendodermal migration directed towards the nearby mesoderm and associate with the somatic gonadal precursor cells (Fig. 2-1) (reviewed in Starz-Gaiano and Lehmann, 2001).

Initially, PGCs exhibit very simple cell morphology with a prominent layer of cortical F-actin adjacent to the plasma membrane. At the onset of gastrulation, the cells undergo extensive cell shape changes when they become polarized and send broad protrusions (Jaglarz and Howard, 1994; Jaglarz and Howard, 1995). During these changes, the F-actin is reorganized thereby residual strong cortical actin is seen in the body of the PGCs whereas the broad pseudopods show nearly no F-actin (Jaglarz and Howard, 1994; Jaglarz and Howard, 1995).

At the time of germ band elongation, PGCs send protrusions in random directions however do not perform active migration instead are passively transported together with the somatic cells. At a later stage rearrangements of the connections among the endodermal cells allow the PGCs to transmigrate through this tissue towards their mesodermal target where they populate the gonad (Jaglarz and Howard, 1994; Jaglarz and Howard, 1995).

Mutational analysis of the process revealed a few genes whose functions are essential for proper PGC migration (Fig. 2-1). Two repellents, WUNEN1 and WUNEN2 from the family of lipid phosphate phosphatase proteins, have been shown to be expressed in areas that the PGCs vacant. In wunen mutant embryos, less germ cells arrive to the gonadal mesoderm as a result of cell scattering in areas that the cells normally avoid. Conversely, ectopic expression of WUNEN1/2 in areas towards which PGCs are normally attracted, transformed the normally attractive target into an area the cells do not enter (Starz-Gaiano et al., 2001; Zhang et al., 1997).

The generation of attractive signals for Drosophila PGCs depend on the function of the 3-hydroxy-3methylglutaryl coenzyme A reductase (HMGCoAR) enzyme. HMGCoAR is normally expressed in the target mesoderm moreover in the corresponding mutant, PGCs fail to reach their target (Van Doren et al., 1998). Interestingly, ectopic expression of HMGCoAR resulted in attraction of germ cells to these locations (Van Doren et al., 1998). 
A Germ Cell Formation

osk, vas, tud

gcl, mtlrRNA

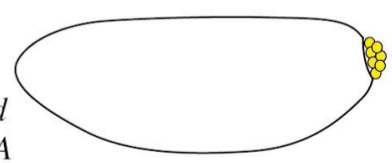

stage 5 $\sim 2.5 \mathrm{~h} \mathrm{AEL}$

B

Germ Band Extension

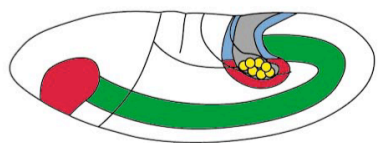

stage 8 $\sim 3 \mathrm{~h} 45 \mathrm{~m}$ AEL

C Migration through Midgut

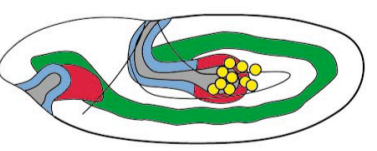

stage 9

$\sim 4.5 \mathrm{~h} \mathrm{AEL}$

D Migration on Midgut and into Mesoderm

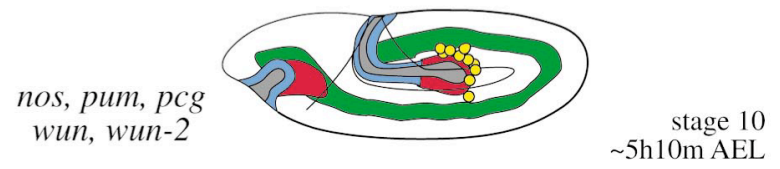
$\sim 5 \mathrm{~h} 10 \mathrm{~m}$ AEL

E Attachment to Lateral Mesoderm

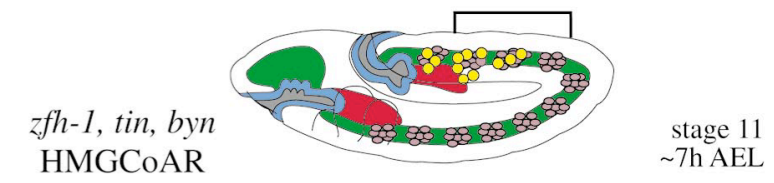

F Alignment with Gonadal Mesoderm

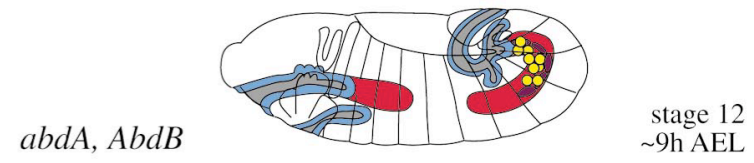

G

tin, cli

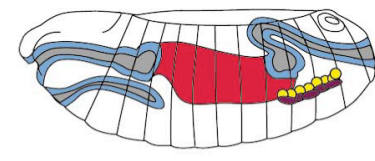

stage 13
$\sim 10.5$ h AEL

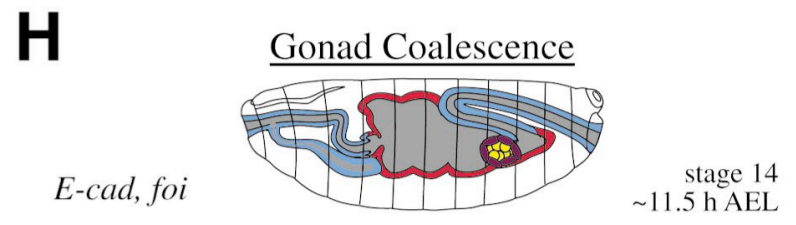

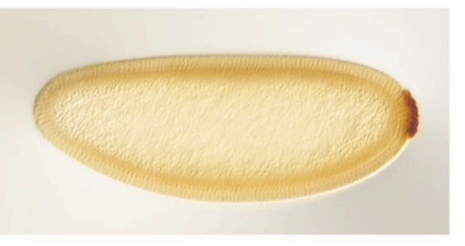
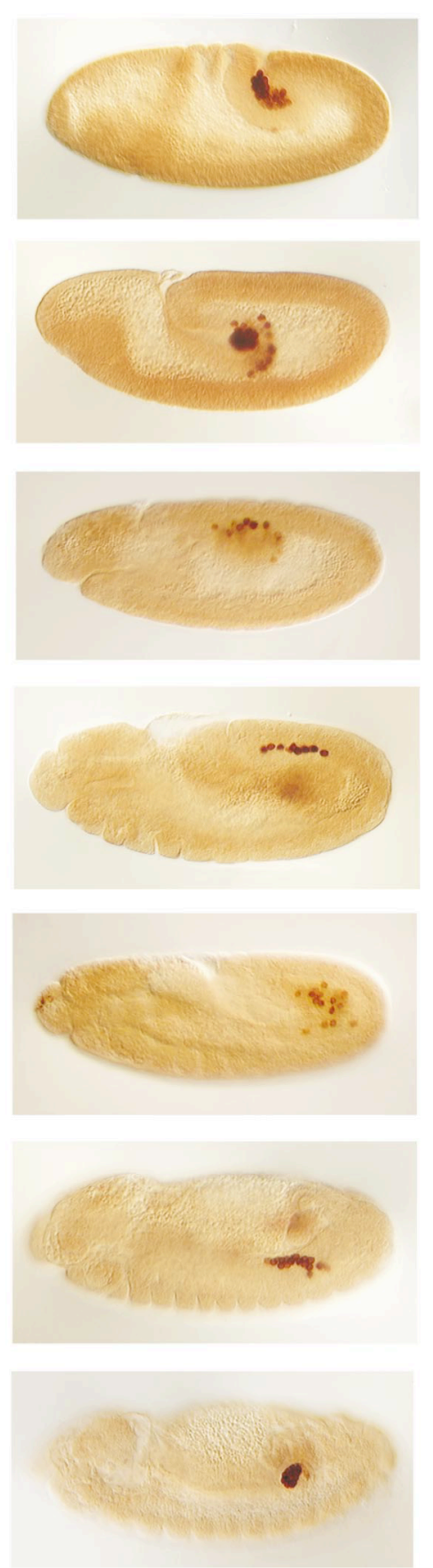

Fig 2-1. Discrete steps in Drosophila germ cell migration. Left hand panels are schematics of the Drosophila embryo. Color code of tissues: yellow: germ cells; green: mesoderm; blue: foregut/hindgut; red: midgut; light purple: lateral mesoderm; dark purple: somatic gonadal precursors. Right panels show antibody staining against Vasa (germ cell marker). Genes essential for each step of migration are listed on the left. (E) The bracket marks the origin of gonadal mesoderm. (Adapted after Starz-Gaiano and Lehmann, 2001) 
Recently, a G-protein coupled receptor (Tre-1) was found to play a role in PGC migration in Drosophila. In Tre-1 mutants the PGCs fail to exit the gut suggesting that the cells need its function to perform transendothelial migration (Kunwar et al., 2003). The ligand that activates the Tre-1 receptor is currently not identified; hence the definite role of Tre-1 in PGC migration or guidance is still not known.

\section{Chick}

After their specification, chick PGCs translocate to the anterior extraembryonic tissue by morphogenetic movements and eventually become incorporated into the new forming vascular system (Ginsburg and Eyal-Giladi, 1987; Tsunekawa et al., 2000). Strikingly, the PGCs circulate in the vascular network and use it as a mean of passive transportation to the region of the gonad (Fig. 2-2) (according to Hamburger and Hamilton from stage $\mathrm{HH} 10$ until $\mathrm{HH}$ 15). Then, the germ cells exit the vascular system and subsequently migrate actively towards the genital ridge (Fig. 2-2, HH 21) (reviewed by Niewkoop and Sutasurya, 1979).

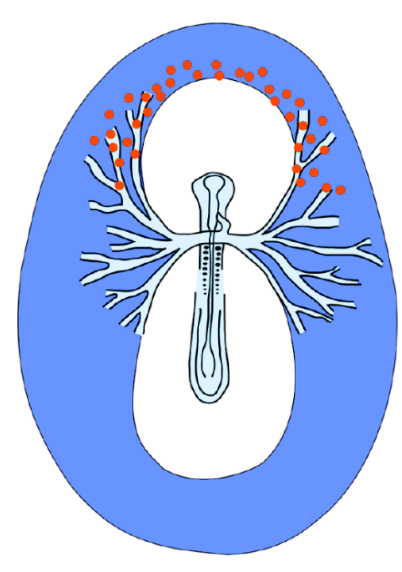

$\mathrm{HH} 12$

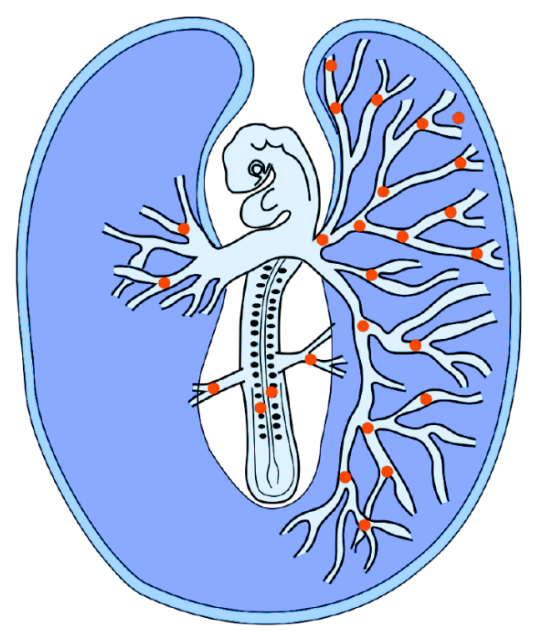

$\mathrm{HH} 15-18$

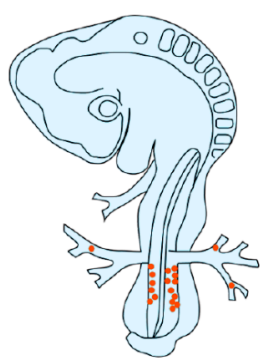

$\mathrm{HH} 21$

Fig. 2-2. PGC migration in the chick embryo. At HH 12, PGCs are already specified and taken up by the forming vascular system. After, the cells are passively circulating in the blood stream as soon as the heart pulsate begins. At HH 15-18, PGCs gradually extravagate the vascular network and migrate actively towards the genital ridge (HH 21).

Previous work indicated that the area of the developing gonad attracts PGCs leading to their extravagation from the vascular network close to their target tissue. For 
instance, PGCs cultured in vitro were attracted and migrated towards cells derived from gonadal tissue (Kuwana et al., 1986). Additionally, chicken germ cells were attracted towards ectopic locations in the embryo, locations where genital ridges of quail embryos were implanted (Kuwana et al., 1986; Kuwana and Rogulska, 1999). Hence, the genital ridge appears to express specific factors, which attract migratory PGCs from the vascular network to cross the epithelium.

Recently it was shown that $s d f-1$ was expressed along the migratory route of the PGCs and in their target tissue. In support of the idea that SDF-1 might be the guidance cue for chick PGCs, expressing SDF-1 ectopically resulted in migration of the germ cells to these locations (Stebler et al., 2004).

\section{Mouse}

At stage E5.5 - E6.5, some epiblast cells receive inductive signals that direct their development to the germ cell linage. Following the specification of these cells, they actively migrate towards the primitive streak (Starz-Gaiano et al., 2001, Saitou et al., 2002, Tanaka and Matsui, 2002). From there, the PGCs cross the primitive streak and migrate into the definitive endoderm (E7.5). At E8.0 - E9.0, the cells are being incorporated into the hindgut-epithelium and then leave the hindgut via transepithelial migration towards the genital ridge (E9.5-E10.5) (Gomperts et al., 1994).

Appropriate interactions between PGCs and the extracellular matrix (ECM) appear to be important for germ cell migration. Molecules such as different classes of cadherins or integrin $\beta 1$ showed to be necessary for proper PGC-PGC coalescence and for efficient gonad colonization respectively (Bendel-Stenzel et al., 2000; Anderson et al., 1999; Di Carlo and De Felici, 2000; Garcia-Castro et al., 1997).

Analysis of mutant mice identified a receptor tyrosine kinase (c-Kit, steel gene) and its ligand (Kit ligand, KL) as key regulators of PGC growth and survival in mouse. KL/c-Kit signalling comprises different effects on cell differentiation, proliferation and survival as well on chemotaxis (Bernex et al., 1996; De Miguel et al., 2002; Gomperts et al., 1994; Matsui et al., 1990). The possible impact of KL/c-Kit signalling in PGC migration and chemotaxis is still under investigation and has to be resolved. 


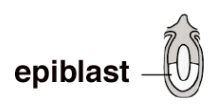

\section{E 6.0 E 7.5}
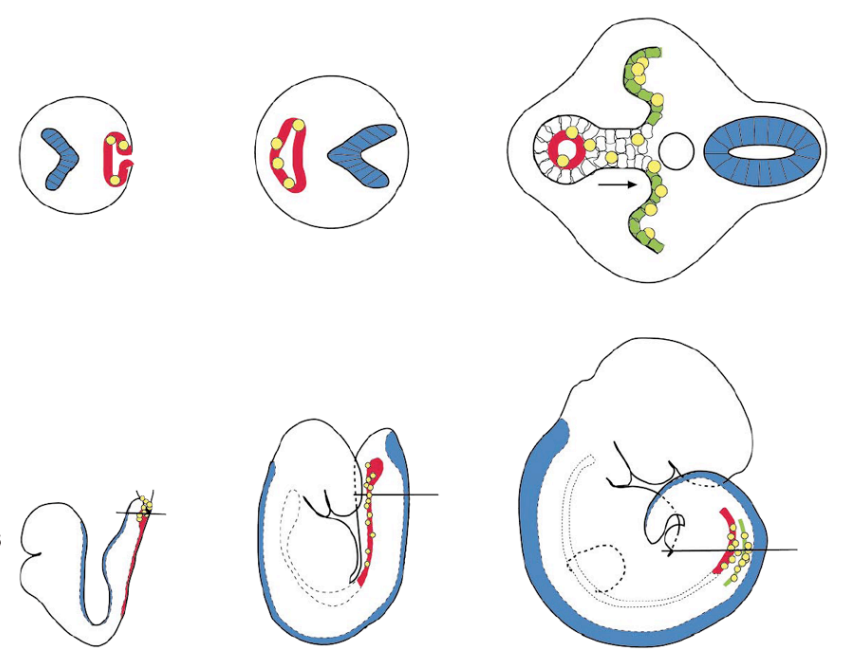

E 10.5

Fig. 2-3. Embryonic mouse development and germ cell migration. Between E5.5 and E6.5, the primordial germ cell precursors are specified from epiblast cells (white). By E7.5, the PGCs (yellow) close to the allantois have formed. At E8.0, germ cells are at the posterior of the developing hindgut (red). The top panels show cross-sections of the embryo at the according stage. At stage E8.0, the germ cells are being incorporated into the hindgut. Around E10.5, the genital ridge has formed (green) which will eventually attract the germ cells. At this stage, the PGCs exit from the dorsal aspect of the gut and migrate towards the position of the developing gonad. (Adapted after Starz-Gaiano and Lehmann, 2001)

The interferon-induced trans-membrane proteins (fragilis/mil/Ifitm), which play a role in mouse PGC specification, appear to be involved in their migration as well. The gene Ifitm 1 is required for PGC migration from the mesoderm into the endoderm and supposedly plays a repulsive role since germ cells stay away from cells expressing Ifitm1 (Tanaka et al., 2005). Recently, the analysis of mouse mutants for the chemokine SDF and for its receptor CXCR4 unveiled that this signalling pathway plays a crucial role in the colonization of the gonad by PGCs. These mutant embryos showed significantly reduced numbers of PGCs in the gonad. Many PGCs did not enter the genital ridge through the hindgut epithelium and were left behind in the mesentery and hindgut. As those PGCs eventually died in CXCR4 mutant embryos, SDF/CXCR4 signalling appears to be needed also for the survival of PGCs before they enter the gonadal tissue (Ara et al., 2003; Molyneaux et al., 2003). However the number and location of PGCs in CXCR4 mutant embryos was not distinguishable different from wild-type embryos at E9.5, which suggests the PGC specification and their initial steps of migration do not require CXCR4 activity (Ara et al., 2003; Molyneaux et al., 2003). 


\section{Zebrafish}

As mentioned before, zebrafish PGCs are specified by maternally provided cytoplasmic determinants, commonly called germ plasm (Braat et al., 1999; Knaut et al., 2000; Köprunner et al., 2001; Yoon et al., 1997).

PGC migration during the first 24 hour of development was initially described by following the RNA expression pattern of a germ cell marker (vasa) (see Fig. 2-4) (Weidinger et al., 1999). Subsequently, germ cell migration was studied in live embryos by labeling the migrating PGCs with fluorescent proteins (Köprunner et al., 2001). PGC migration analysis in specific mutants revealed that cluster formation of germ cells at an intermediate target (see Fig. 2-4, 2-somite stage) depends on proper differentiation of somatic mesodermal cells in that region. Taken together, the conclusions from these studies was that PGCs actively migrate towards the intermediate and final targets where somatic cells provide the signals to attract them (Weidinger et al., 2002).

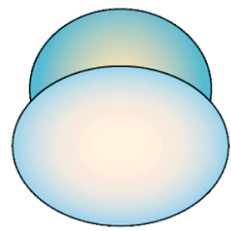

1 cell, lateral

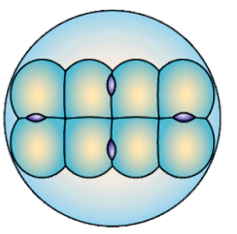

8 cell, animal

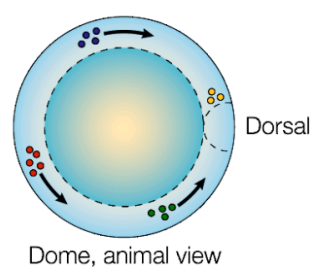

Dome, animal view

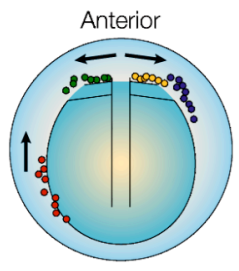

2 somites, dorsal view

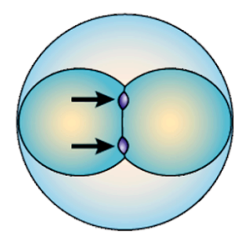

2 cell, animal
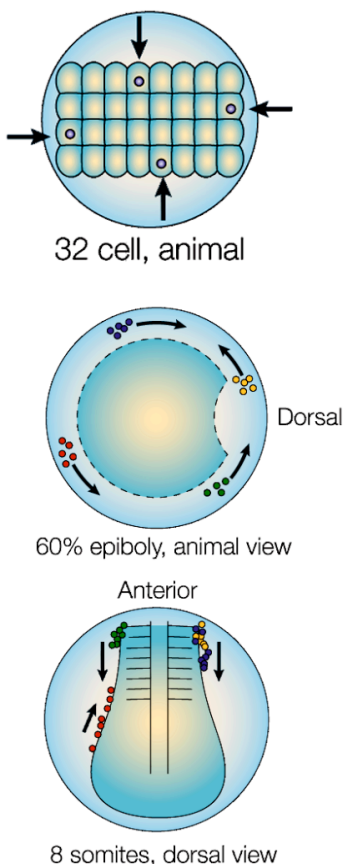

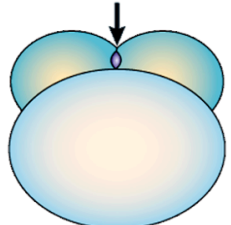

2 cell, lateral
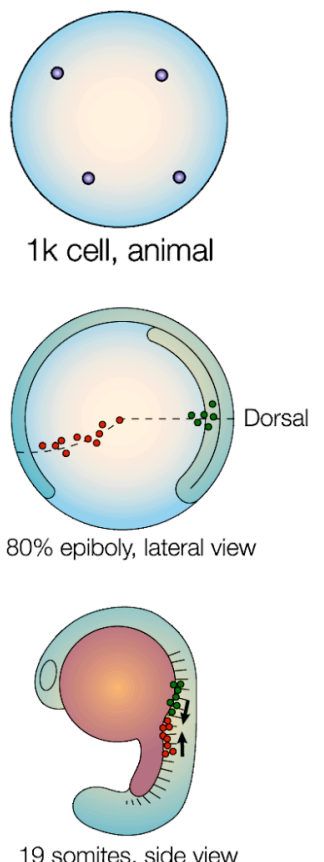

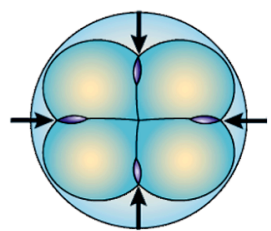

4 cell, animal
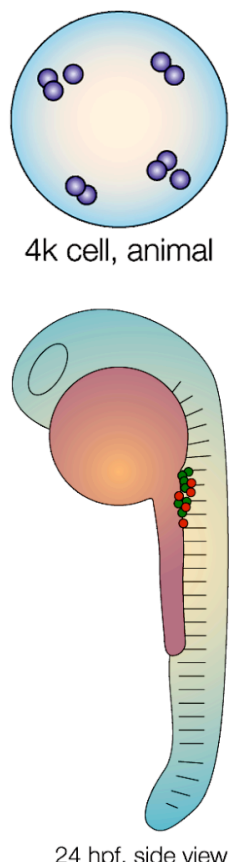

Fig 2-4. Specification and migration of zebrafish PGCs.

Schematic summary based on the distribution of vasa RNA in the early embryo and the germline. 
1-cell stage: maternal vasa RNA is uniformly distributed

2-/4-cell stage: germ plasm determinants getting localized to the first two cleavage planes (black arrows)

32-cell stage: four condensed clumps of germ plasm are asymmetrically distributed during mitosis (black arrows)

1k-cell stage: just four cells contain the clumps of germ plasm

4k-cell stage: the cells that inherited vasa RNA - the PGCs - have begun to divide (each daughter cell inherits germ plasm, symmetrical cell division)

dome stage: four clusters of PGCs are found close to the blastoderm margin in a symmetrical 'square' shape. All possible orientations of the square relative to the dorsal side of the embryo can be observed. Here, an intermediate arrangement is shown with one cluster close to, but not directly at the dorsal side. 60\%-epiboly stage: loss of the 'square' arrangement of PGC clusters, PGCs from the ventral move in direction to the dorsal and dorsal located PGC clusters exclude the dorsal midline where the notocord will form.

80\%-epiboly stage: dorsally located PGCs align along the border between the head and trunk paraxial mesoderm marked by the dashed line. Ventrally located PGC clusters align at the lateral border of the mesoderm.

2-somite stage: most PGCs arrived in two lines at the level of the first somite. These anterior located PGCs migrate towards the lateral and form two lateral clusters. Cells that were initially located ventrally migrate towards the anterior along the anlage of the pronephros (anterior migration of trailing PGCs). In this illustration, the positions of the PGCs are drawn relative to the adaxial cells, the somites and the lateral border of the pronephric anlage.

8-somite stage: all anterior PGCs are found lateral to the paraxial mesoderm in a cluster extending from the 1 st to the 3 rd somite. These clusters start to move towards the posterior while the trailing cells tightly align on the lateral border of the pronephros and continue to migrate anteriorly.

19-somite stage: the main clusters have shifted to more posterior positions and in $60 \%$ of embryos some trailing cells are still seen.

24 hpf: the PGC clusters are located at the anterior end of the yolk extension, which corresponds to the 8th to 10th somite level. In most embryos, all PGCs have reached this region, only a few trailing cells are found close to the main clusters. (Adapted after (Raz, 2003; Weidinger et al., 1999))

Interestingly, during their migration phase, PCGs alternate between migratory (runphase) and pausing (tumbling-phase) modes (Reichman-Fried et al., 2004). Pausing periods are characterized by loosing cell polarity following a change in the direction of migration. These modes represent an intrinsic behaviour of migrating PGCs, which might be needed to erase prior directionality subsequently readjusting to the environment presenting the directional information for migration (Reichman-Fried et al., 2004). 
The signal that attracts the PGCs towards their targets was revealed in a morpholino (antisense oligo nucleotide) based screen where the function of the a G-protein coupled receptor (CXCR4b) was shown to be essential for directional migration of zebrafish PGCs (Doitsidou et al., 2002). The ligand of this receptor, the chemokine SDF-1a was found to be dynamically expressed in the regions towards the PGCs migrate (Doitsidou et al., 2002; Knaut et al., 2003). Notably, ectopic expression of SDF-1a could attract PGCs to the new location showing that this ligand is sufficient for attracting the PGCs in zebrafish (Doitsidou et al., 2002). The precise mechanisms translating the SDF-1 signals into cell polarization and directed migration are currently unknown. Whereas PGCs lacking CXCR4b exhibit severe defects in directional migration, cell motility per se is not affected.

Recently, it was shown that $\mathrm{G}$ proteins of the Gi family play a crucial role in directed PGC migration whereas cell motility was not dependent on Gi signalling (Dumstrei et al., 2004). In addition, altered PI3K activity or reduced levels of phosphorylated phosphoinositides did affect germ cell motility and cell morphology (Dumstrei et al., 2004).

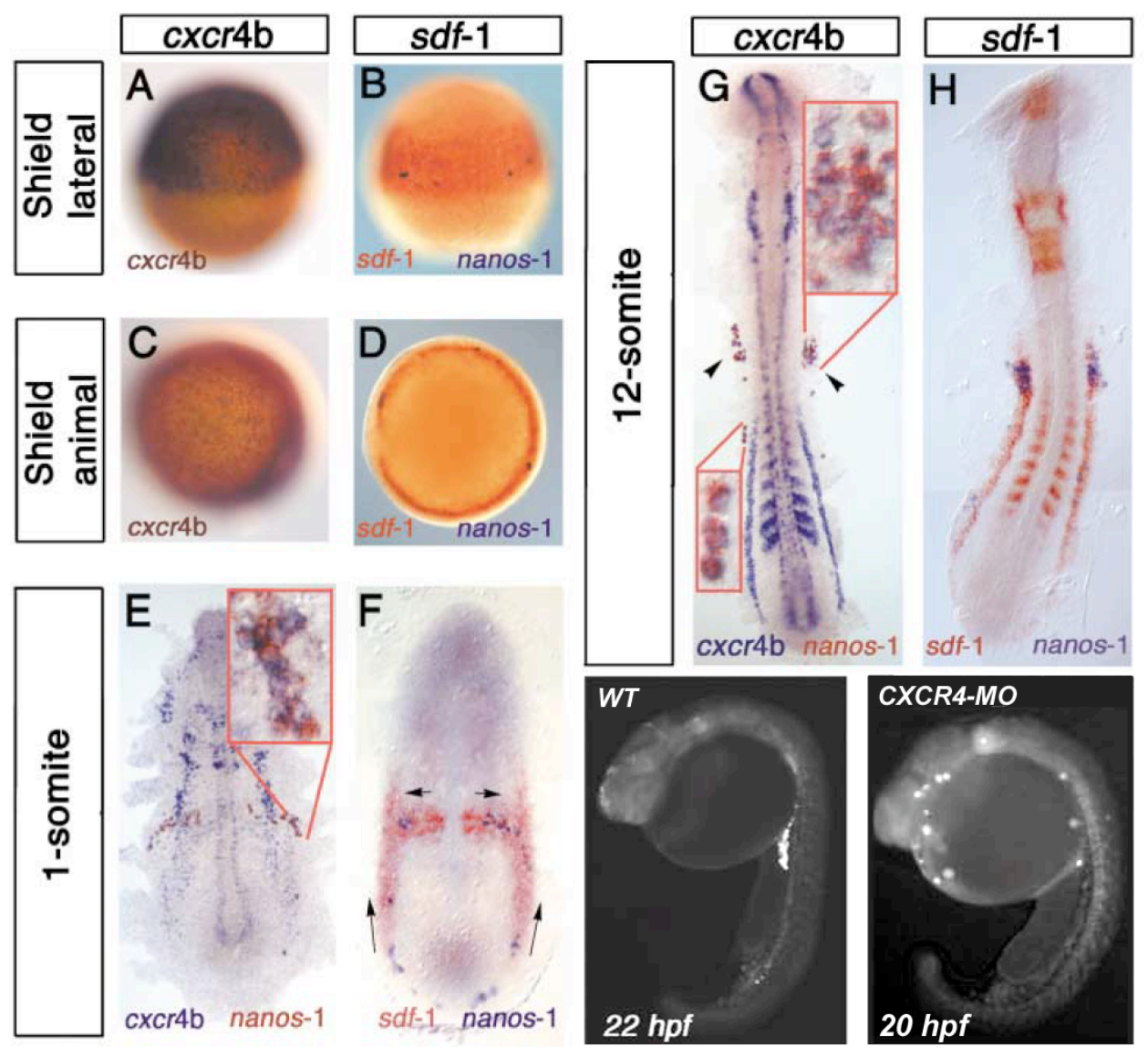


Fig. 2-5. Expression pattern of CXCR4b and SDF-1a and alteration of SDF-1a signalling. (A, C, E, and G) Distribution of CXCR4b transcripts in wild-type embryos from gastrulation to midsomitogenesis stages. (A,C) During early gastrulation the mRNA of the receptor is uniformly distributed. (E,G) Tissue-specific pattern is evident during somitogenesis stages when the PGCs coexpress cxcr4b (blue) and the PGC-specific RNA, nanos-1 (red). (B, D, F, and H) The expression pattern of $s d f-1$ a mRNA (red) relative to the position of the PGCs (blue). (B, D) Expression of $s d f-1$ mRNA during gastrulation. (F) $s d f$-1a expression during early somitogenesis. Depending on their position at this stage, the PGCs migrate laterally or anteriorly (arrows). (H) During somitogenesis, $s d f$ 1a is expressed along the border of the trunk mesoderm, in the somites, and in specific domains in the head. In embryos injected with control morpholino $(W T)$, the PGCs migrate towards the position where the gonad will form. Inhibiting the translation of cxcr4b (CXCR4-MO) results in random migration with cells arriving at ectopic positions. (Adapted after Doitsidou et al., 2002)

A gene whose function is crucial for PGC motility and specification is the zebrafish Dead end, a putative RNA binding protein. Currently, the definite role of Dead end in PGC specification and migration is unknown, but it is likely that defining the biochemical cascade in which this molecule participates will provide important clues regarding the acquisition of cell motility (Weidinger et al., 2003).

\subsection{Aim of the thesis}

The focus of this thesis was the investigation of the molecular and cellular mechanisms governing the transition from non-motile to motile behaviour of zebrafish primordial germ cells.

Furthermore, we paid special attention to define the molecular basis for germ cell polarization and directional migration in response to the chemoattractant SDF-1a. 


\section{$3 \quad$ Results}

\subsection{The askopos gene is expressed in the zebrafish germline and encodes a $\underline{\text { nuclear protein }}$}

The askopos (kop) gene (askopos, "without purpose" in Greek) was identified in a screen for genes that are expressed in zebrafish PGCs (Thisse et al., 2001). Maternally-provided kop RNA is uniformly distributed at the 1-cell stage embryo and becomes enriched at the cleavage furrows at $0.75 \mathrm{hpf}$ and $1 \mathrm{hpf}$ (2- and 4-cell stages) (Fig. 3-1A).

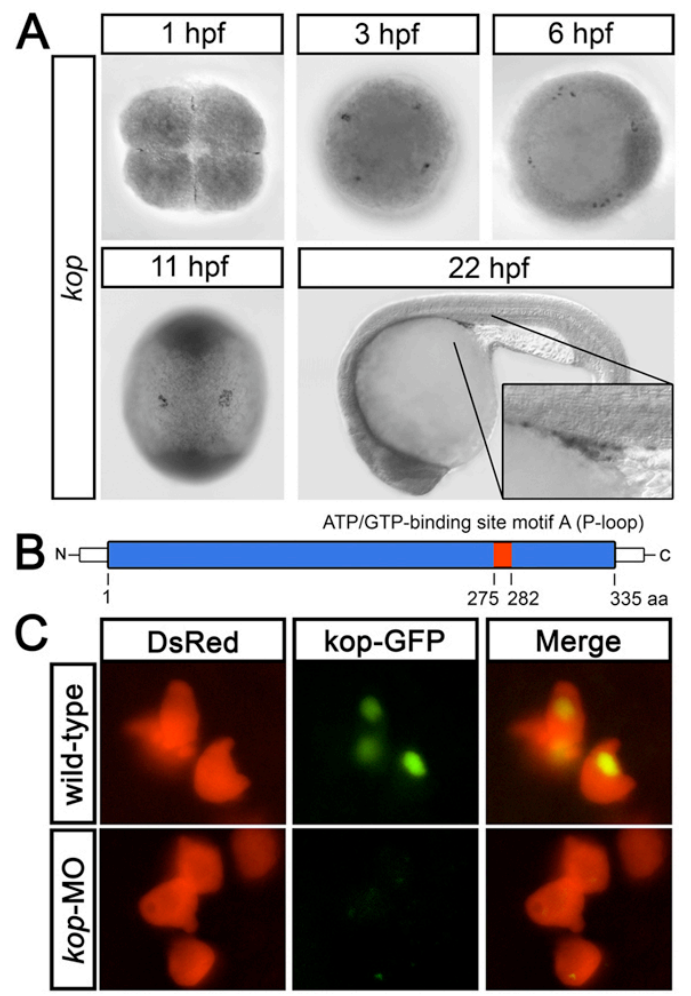

Fig. 3-1. kop RNA is expressed in the germ plasm and the encoded protein is localized to the nucleus. (A) The expression pattern of kop RNA during the first day of zebrafish development. kop RNA is localized to the cleavage furrows at the 1 hpf (4-cell stage) and is then expressed in PGCs. The inset included in the image depicting a $22 \mathrm{hpf}$ embryo shows a magnification of the region where the PGCs are normally found. (B) Graphical illustration of the open reading frame of the Kop protein, which contains an ATP/GTP-binding site A. (C, upper panels) PGCs in a 10.5 hours old (1somite stage) embryo co-injected with DsRedexnos1-3'UTR (red channel) and kop-gfp-nos13'UTR (green channel). The merged picture shows that the Kop-GFP fusion protein is localized to the nuclei of PGCs. (C, lower panels) PGCs in a 10.5 hours old (1-somite stage) embryo co-injected with DsRedex-nos1-3'UTR (red channel), kop-gfp-nos13'UTR (green channel) and kop-specific morpholino antisense oligonucleotides (kop-MO). Translation of Kop-GFP fusion protein is inhibited, whereas DsRed expression is not affected.

The RNA is then expressed in the PGCs as they migrate towards the gonad and can no longer be detected in 5-days old embryos (Fig. 3-1A and data not shown). This expression pattern is comparable to that of nanos 1 and dead end that play a role in 
early PGC development in zebrafish, and differs from that of vasa that is continuously expressed in the germline (Köprunner et al., 2001; Weidinger et al., 2003; Yoon et al., 1997).

kop mRNA encodes a novel 335 amino acid protein which contains an ATP/GTP-binding site motif A referred to as P-loop, (Saraste et al., 1990) (Fig. 31B). Interestingly, no homologues to the Kop protein could be identified in other species and hence the molecular function of such proteins is unknown. Therefore, we first wished to determine the subcellular localization of the Kop protein. A Kop-GFP fusion protein expressed in the PGCs revealed its localization to the nuclei (Fig. 3$1 C)$, suggesting that its function could be exerted in the nucleus.

\subsection{Alterations in the level of Kop activity}

We initially overexpressed kop RNA throughout the embryo by injecting RNA containing kop open reading frame fused to globin 3'UTR. Despite the high amounts of injected RNA (up to 900pg of kop-globin-3'UTR RNA per embryo) we could not detect abnormalities in either somatic or PGC development. Similarly, overexpression of kop in the PGCs by injection of kop-nos1-3'UTR RNA had no effect on PGC development; those arrived at the region of the gonad and expressed vasa RNA.

Subsequently, we aimed at reducing Kop's activity using modified antisense oligonucleotides (morpholinos, kop-MO). Injection of antisense oligonucleotides directed against the 5' of kop RNA effectively blocked the translation of the kop-gfpnos 1-3'UTR RNA as demonstrated in Fig. 3-1C. Nevertheless, we failed to detect any abnormalities in PGC development as judged by normal migration of the cells and normal expression of vasa RNA.

As increasing the amount of kop RNA as well as inhibiting its translation had no effect on PGC development, we reasoned that similar to other examples in zebrafish (e.g. Gritsman et al., 1999) maternally-provided Kop protein could be sufficient to carry out the early function of the gene. We therefore attempted to inhibit the function of such putative maternal protein by expressing a dominant negative (DN) form of Kop in the PGCs. A mutated form of the Kop protein was constructed by exchanging a conserved glycine in the P-loop motif with a serine residue. Such mutations showed to be sufficient to inhibit the ATP binding ability of the P-loop 
motif. However, overexpression of this protein by injecting embryos with DNkopglobin-3'UTR RNA did not affect PGC development.

As none of the manipulations appear to affect normal PGC development it is possible that the function of Kop is redundant, that our knockdown approaches did not reduce its activity to a level low enough to be phenotypically manifested or as suggested by its name, the protein plays no role in PGC development.

\subsection{Employing the kop promoter to establish a transgenic fish line expressing EGFP-F during early PGC development}

To follow PGC migration in live embryos, we have routinely labeled these cells with GFP relying on 3'UTR elements that confer specific expression in PGCs (Köprunner et al., 2001; Wolke et al., 2002). Others have used transgenic fish in which GFP was flanked by an upstream EF1 $\alpha$ or vasa promoter and by the downstream 3'UTR of the vasa gene (Knaut et al., 2002; Krøvel and Olsen, 2002). Monitoring PGCs in live embryos using either one of these approaches allowed clear visualization of the cells albeit not earlier than mid-gastrulation stages (ca. 7 hours of development).

We set out to take advantage of kop (askopos, kop), whose RNA is maternally provided, localized to the germ plasm and expressed in the PGCs during the first day of development (see Fig. 3-1). The strong expression of kop in early embryos prior to the initiation of zygotic transcription implies that its RNA is transcribed during oogenesis. Considering this notion we sought to monitor the behaviour of the PGCs from the earliest stages of their development by generating a construct in which the kop promoter was positioned upstream to EGFP containing a farnesylation signal (EGFP-F; the farnesylation signal sequence assures plasma membrane localization of the protein) followed by the 3'UTR of the nanos1 gene that stabilizes the RNA specifically in the PGCs (Fig. 3-2A). This construct was injected into 1-cell stage embryos and a transgenic line carrying the construct was established. Heterozygous females carrying one copy of the transgene were mated with wild-type males and the progeny (half of which inherited the transgene) were analyzed by in situ hybridization using EGFP as a probe. Both transgenic and non-transgenic offspring exhibited the same RNA expression pattern as shown in Fig. 3-2B, consistent with the idea that the kop promoter is active prior to the first meiotic 
division. The RNA of the transgene is ubiquitously distributed at 1-cell stage and becomes enriched in the cleavage planes at 0.75 hours post fertilization (hpf) and 1 hpf (2- and 4-cell stages) (Fig. 3-2B). This result indicates that similar to the 3'UTR of the vasa gene (Knaut et al., 2002; Krøvel and Olsen, 2002), the 3'UTR of nanos 1 is sufficient for localizing the RNA to the germ plasm.

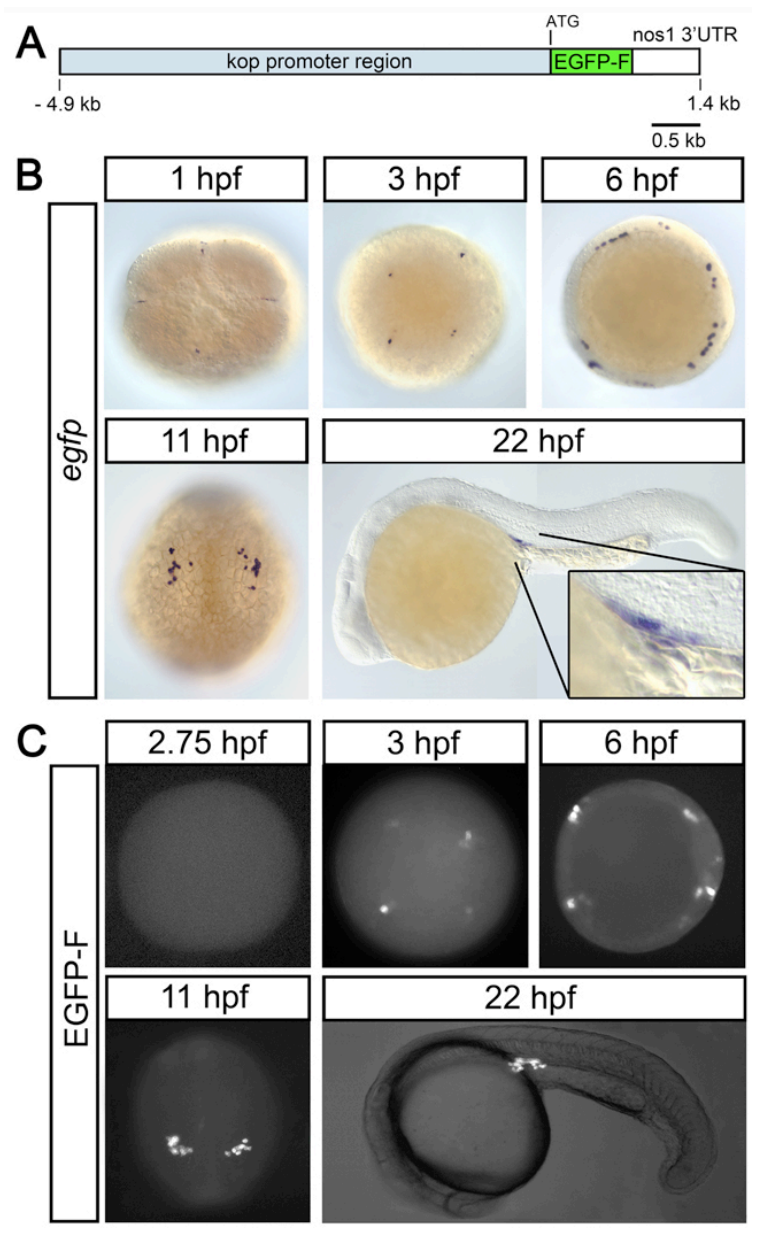

Fig. 3-2. Early labelling of PGCs in live embryos. (A) Schematic representation of the kop promoter region fused to EGFP-F-nos1-3'UTR that was used to generate transgenic fish. (B) Whole mount in situ hybridization of progeny of transgenic females showing the distribution of egfp RNA. The inset included in the image depicting a $22 \mathrm{hpf}$ embryo shows a magnification of the region where the PGCs normally reside. (C) Specific expression of EGFP-F in the zebrafish germline starting at the earliest stages following its formation. No specific EGFP-F expression prior PGC specification (e.g. $2.75 \mathrm{hpf}$ ) can be detected.

Later, expression of egfp- $f$ RNA is observed in PGCs during their migration toward the region of the gonad and can be detected in these cells during the next three days (Fig. 3-2B). In agreement with the notion that the kop promoter is strictly maternal, 
the progeny of transgenic males mated with wild-type females showed no expression of $e g f p-f$ RNA (data not shown).

\subsection{Early EGFP expression in the PGCs}

In progeny of transgenic females, EGFP is detectable in PGCs starting at $3 \mathrm{hpf}$ (Fig. 3-2C). Only faint uniform EGFP protein expression could be detected prior to PGC specification (2.75 hpf in Fig. 3-2C) unlike the strong somatic expression of GFP that is observed when other promoters and vasa-derived RNA elements are used (Knaut et al., 2002; Krøvel and Olsen, 2002). These results support the notion that RNAs containing the 3'UTR of nanos 1 are silenced on the level of translation until the midblastula transition (about $3 \mathrm{hpf}$ ), which is the onset of zygotic transcription.

Thus, owing to the kop-EGFP-F-nos1-3'UTR transgene, PGCs can be visualized with great clarity in live embryos as soon as they are specified. In the context of this study, the kop-EGFP-F-nos 1-3'UTR transgenic line enabled us to examine PGCs in live embryos during stages that have not been previously amenable to investigation.

\subsection{The onset of PGC migration in zebrafish}

When PGC migration was originally described based on the analysis of fixed embryos, the first stage of active migration was shown to occur at about $5.5 \mathrm{hpf}$ (before shield stage) (Weidinger et al., 1999). This type of analysis provided no information regarding the dynamic cellular mechanisms responsible for promoting the transition of the cells into a motile phase and the acquisition of responsiveness to guidance cues. Such a transition in cell behaviour is exhibited by many cell types in normal development (e.g. Christiansen et al., 2000; Savagner, 2001) and disease (e.g. Thiery, 2002). For example, following their specification, neural crest cells delaminate from the neuroepithelium of the developing neural tube and become migratory (Halloran and Berndt, 2003; Savagner, 2001). A comparable transition is observed in border cells that delaminate from an epithelium and invade a different cellular environment on their way to the target tissue (Rørth, 2002; Starz-Gaiano and 
Montell, 2004). Similarly, cancer cells undergo changes in the cellular phenotype as they leave an organized epithelial layer, acquire an invasive phenotype and initiate metastasis (Thiery, 2002). To characterize the behaviour of the PGCs during this critical time point, we monitored the cells from 3 hpf using low magnification timelapse analysis. At this stage, PGCs are found in four clusters and show no movement relative to their somatic neighbours (Fig. 3-3A). It is only at about $4.5 \mathrm{hpf}$ (the end of dome stage), about 1.5 hours after PGCs exhibit specific nos 1-3'UTR controlled EGFP-F expression, that a few cells start leaving the clusters (Fig. 3-3A).

To study these early steps of PGC behaviour at a higher resolution, we observed the cells at these stages ( 3 to $4.7 \mathrm{hpf}$ ) by generating high magnification timelapse movies. Based on cell morphology and motility we could define 3 phases of early PGC development. The first phase is characterized by simple PGC morphology and lack of migration (Fig. 3-3B, $\mathrm{n}=8 / 8$ cells in 7 embryos). During the second phase that starts about 30 minutes later $(3.3 \mathrm{hpf})$, the germ cells extended primarily multiple small protrusions in all directions as well as unusually elongated protrusions ( $n=14 / 14$ cells in 11 embryos), but still showed no net movement (Fig. 3-3C). This complex morphology that is observed during the next 40 minutes disappears when the cells undergo mitosis (Fig. 3-3D). In the last phase, which starts at about $4.5 \mathrm{hpf}$, a few polarized cells extending broad pseudopodia characteristic of migratory PGCs (Reichman-Fried et al., 2004) show bona-fide active migration.

The proportion of such cells gradually increased so that at $4.7 \mathrm{hpf}$ about $30 \%$ of cells assumed migratory behaviour and about $50 \%$ of PGC showed polarized cell morphology (Fig. 3-3E, 8/11 cells in 8 different embryos). At 5.5 hpf about $75 \%$ of cells show active migration and at $6 \mathrm{hpf}$ this number increased to more than $90 \%$ of all PGCs. Whereas the phases described above are likely to represent steps in the cellular maturation of PGCs, it is formally possible that they actually reflect alterations in the properties of their early environment. To test this possibility, we have transplanted migratory PGCs into early host embryos (namely, 12 hpf PGCs into 3 hpf embryos). Notably, the transplanted cells exhibited cellular behaviour characteristic of their developmental stage when present in early host embryos whose endogenous PGCs show no movement (Fig. 3-3F, G, $n=4 / 5$ cells in 3 embryos). Indeed, the transplanted cells reached the site where the gonad develops by the end of the first day of development (data not shown). 


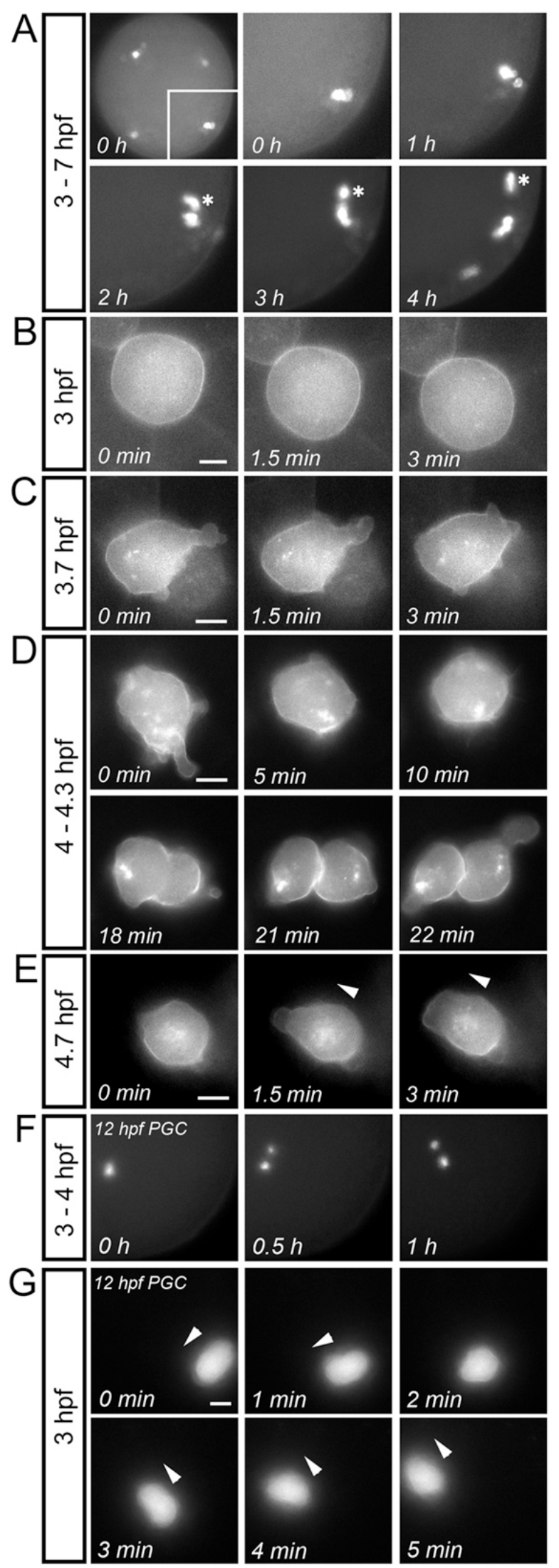

Fig. 3-3. Marked alterations in migratory behaviour are detectable during earliest stages of PGC development. (A) Snapshots from a low magnification time-lapse movie recorded over 4 hours of zebrafish development. The area marked in the top left panel is magnified in the rest of the panels. The germ cells remain in their positions for about 1.5 hours following PGC specification and start to migrate actively around dome stage ( $4.5 \mathrm{hpf}$, $\mathrm{n}=4$ embryos). An asterisk marks a PGC, which leaves the cell cluster. (B-E) Highmagnification snapshots from time-lapse movies of wild-type embryos (B) At $3 \mathrm{hpf}$, PGCs exhibit simple morphology. (C, D) At $3.7 \mathrm{hpf}(\mathrm{C})$ up to $4.3 \mathrm{hpf}$ (D) the cells develop small, as well as long complex protrusions extended in random directions, yet are not polarized and do not migrate. At these stages, the cells show round morphology during cell divisions (D). (E) Soon after 4.3 hpf, PGCs exhibit polarized elongated cell morphology and extend pseudopodia in the direction of migration. (F) Snapshots from a low magnification 1-hour long time-lapse movie of PGCs from a 12 hours donor embryo in a $3 \mathrm{hpf}$ host embryo. The transplanted cells migrate in the early host ( 3 cells in 2 embryos examined). (G) Transplanted cells similar to those in $F$ show polarized elongated cell morphology and migration behaviour similar to PGCs after 4.3 hpf (40x magnification). The white scale bars represent $10 \mu \mathrm{m}$ and the white arrowheads indicate the direction of migration.

The transplanted PGCs exhibited polarized formation of protrusions and importantly, occasionally exhibited "run and tumble" behaviour (Reichman-Fried et al., 2004). Namely, we occasionally observed loss of cell polarity coupled with a 
change in the direction of migration. This experiment thus clearly demonstrated that early in development, PGC competence to polarize and migrate constitutes an autonomous property of these cells.

\section{6 de novo transcription in the zygote and Dead end function are essential for the cellular maturation of PGC}

To determine whether zygotically transcribed genes are involved in the cellular maturation of zebrafish PGCs we have treated the embryos with the RNA polymerase II and III inhibitor $\alpha$-amanitin (Jacob et al., 1970). As previously described (Kane et al., 1996), inhibition of zygotic transcription (assayed by the effect on notail transcription Fig. 3-4B) did not affect cell division, but had a dramatic effect on early gastrulation movements, most notably on epiboly (Fig. 3-4A). Despite the strong effect of this treatment on morphogenetic movements, we could not observe any indications for an effect on PGC survival. Specifically, we could not detect activation of caspases that would indicate the initiation of caspase dependent programmed cell death in the PGCs (Fig. 3-5B, 12/12 embryos) and could not observe dying PGCs for as long as we followed the treated cells (until $9 \mathrm{hpf}$, that is 4.5 hours after they normally become motile, Fig. 3-5B and Fig. 3-4C).

Interestingly, an adverse effect on PGC migration was observed in $\alpha$ amanitin treated embryos as evident by PGCs remaining in their original cluster several hours following the time at which they normally become motile (Fig. 3-4C, 4/4 embryos). Strikingly, the inhibition of transcription brought PGC maturation to a halt as manifested by lack of motility and polarity while extending protrusions in all directions. These characteristics signify an arrest of PGC differentiation at the second phase (Fig. 3-4D, 11/11 cells). As the $\alpha$-amanitin treatment affected both the transcription in the PGCs as well as in somatic cells, we sought to determine the relative contribution of each one of these populations to the observed phenotype. To this end, we have transplanted motile PGCs from untreated embryos into $\alpha$-amanitin treated hosts and examined their behaviour. Interestingly, whereas we found that the transplanted cells exhibited morphological behaviour characteristic of their developmental stage as they were producing broad pseudopodia typical of migrating 
PGCs (Fig. 3-4E, 11/11 cells), they did not migrate relative to the $\alpha$-amanitin treated somatic cells. As we ruled out the possibility that $\alpha$-amanitin from neighbouring cells can affect transcription in cells that did not receive the chemical themselves (data not shown), the result of this experiment points to the requirement for active transcription in surrounding somatic cells, presumably for providing PGCs with the extracellular matrix or cell adhesion conditions that are permissive for active migration. Conversely, $\alpha$-amanitin treated PGCs transplanted into untreated host embryos displayed morphological characteristics and protrusive activity suggesting that they are arrested in the second phase of PGC maturation. These cells exhibit multiple small as well as unusually elongated protrusions in all directions and did not migrate relative to the wild-type somatic cells (Fig. 3-4F, 6/8 cells). Importantly, the $\alpha-$ amanitin treatment did not affect PGC survival during the stages we analysed so that live GFP labelled PGCs could be observed in ectopic positions in 24 hours old embryos. Together, these data suggest that maternal contribution of RNA and proteins is not sufficient for the transition of the PGCs to become polarized and perform active migration and that de novo transcription within these cells is essential for the process.

A gene product whose function is required for PGC motility in zebrafish is Dead end (Weidinger et al., 2003). To determine whether early steps in PGC development require the function of Dead end, we monitored the cells in embryos injected with dead-end (dnd)-morpholino antisense oligonucleotides (dnd-MO). Interestingly, PGCs depleted for Dead end showed normal cell morphology and behaviour during the first two phases of their development (Fig. 3-4G, 14/14 cells in 11 embryos). Noticeably however, in embryos lacking Dead end the PGCs did not undergo the transition to the last phase at which they normally polarize, extend broad pseudopodia and actively migrate. PGCs in $d n d$-MO treated embryos nevertheless do exit the second phase of cellular development as they cease to extend the protrusions characteristic of this step (Fig. 3-4G, 9/10 cells in 8 embryos), unlike $\alpha$-amanitin treated PGCs that appear to be arrested in this phase. Once Dead end knock-down PGCs exit the second phase of maturation, they show primarily simple cell morphology no polarization and do not migrate. Despite the fact that these cells eventually die, we believe the phenotype we observe reflects a specific requirement for Dead end function, as the treated cells are capable of extending filapodia as well as small protrusions and continue to divide (e.g. Fig. 3-4G). 
Dead end function is therefore dispensable for early maturation steps of PGCs but essential for attaining migratory properties.

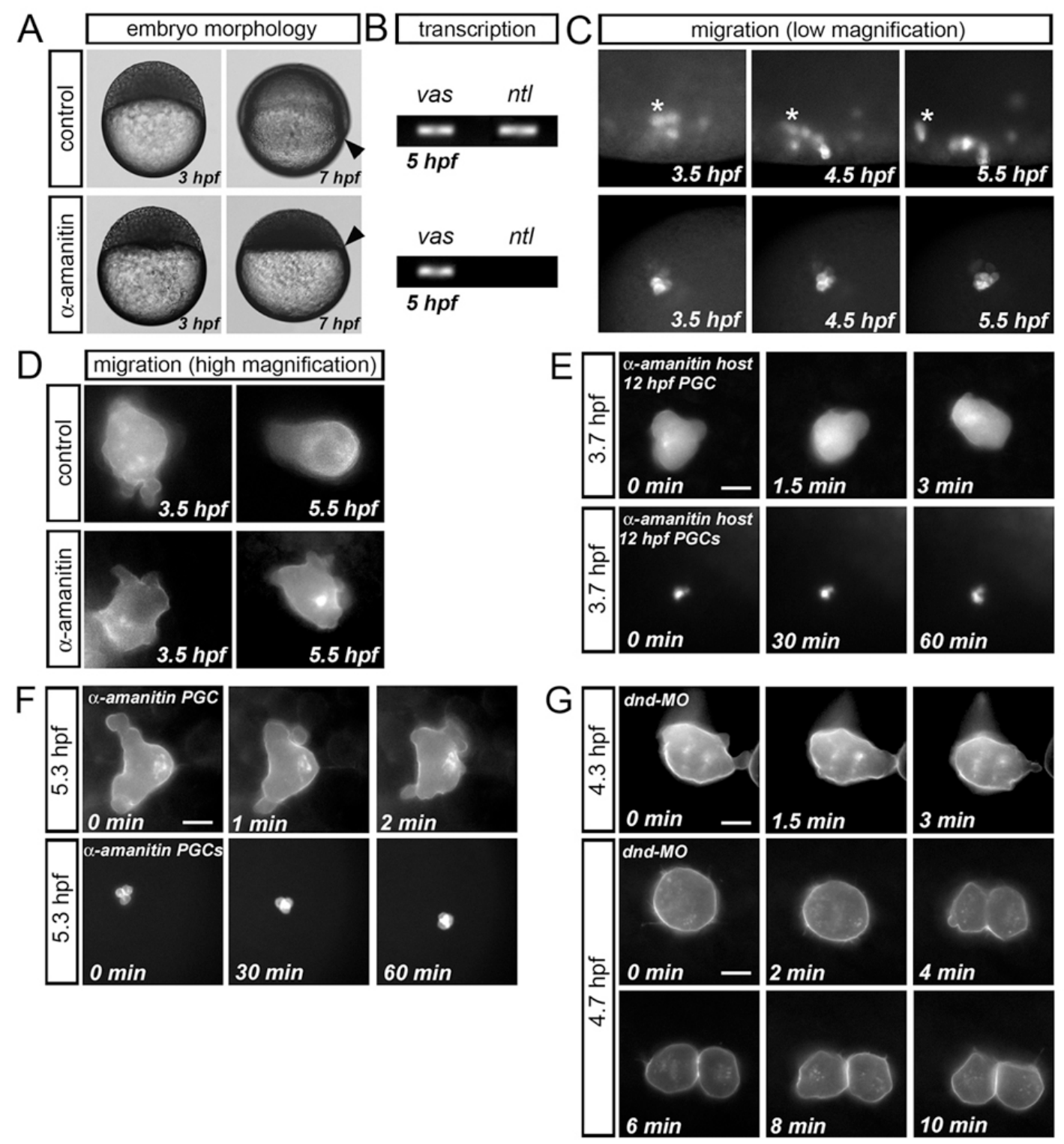

Fig. 3-4. Zygotically transcribed genes are essential for PGC polarization and motility. (A) Embryos treated with $\alpha$-amanitin (lower panels) exhibit gastrulation defect, most pronounced is the inhibition of epiboly (arrowheads). (B) Transcription of the zygotically expressed genes (represented here by RT-PCR analysis for notail $(n t l)$ ) is inhibited by $\alpha$-amanitin (lower panel) whereas the level of maternally-provided transcripts (represented here by RT-PCR analysis for vasa (vas)) is unaffected. (C) Snapshots from low-magnification time-lapse movies recorded over 2 hours of zebrafish development showing a representative PGC cluster. The germ cells in control embryos (upper panels, one cell labeled with an asterisk) migrate actively and leave the cluster following the transition whereas PGCs in $\alpha$-amanitin treated embryos (lower panels) remain clustered and immotile. 
(D) Snapshots from high-magnification time-lapse movies of control (upper panels) and $\alpha$-amanitin treated PGCs (lower panels). PGCs treated with $\alpha$-amanitin remain arrested in the second phase of their differentiation extending protrusions in all directions and fail to polarize. (E) Snapshots from high-magnification time-lapse movies. $12 \mathrm{hpf}$ old wild-type PGCs transplanted into an $\alpha$-amanitin treated host embryo are not able to migrate relative to host cells, but show cell morphology characteristic of cells of their age. (F) $7 \mathrm{hpf}$ old $\alpha$-amanitin treated PGCs transplanted into a $5.3 \mathrm{hpf}$ wild-type host remain arrested in the second phase of their maturation displaying extensions in all directions and fail to polarize and migrate. The apparent movement of the cluster in the lower panels is a result of passive movement together with somatic cells. (G) At 4.3 hpf, Dead end knockdown (dndMO) PGCs behave like wild-type cells of a similar age. At $4.7 \mathrm{hpf}$, $d n d$-MO treated germ cells do not polarize and migrate but are capable of extending small protrusions and divide. White scale bars represent $10 \mu \mathrm{m}$.

\section{$\underline{3.7} \alpha$-amanitin and $d n d$-MO treated PGCs undergo caspase independent cell death during advanced stages of embryonic development}

Whereas PGCs treated with dnd-MO eventually die (Weidinger et al., 2003), we sought to determine the time and mode of PGC death, therefore we have applied an in vivo assay to detect activated caspases. In the control experiment, one of 64 blastomeres (at $2 \mathrm{hpf}$ ) was co-injected with diphtheria toxin RNA and Oregon green 488 fluorescent dye. At $4.5 \mathrm{hpf}$, a clone of somatic cells, which inherited the diphtheria toxin RNA, and the Oregon green 488 fluorescent dye showed positive staining for activated caspases (Fig. 3-5A, 3/3 observed embryos).

$\alpha$-amanitin treated embryos revealed no caspase positive PGCs neither at 5 hpf nor at 9 hpf, shortly before the embryo died. However, at 9 hpf a few somatic cells exhibited positive staining demonstrated that the assay was functional (Fig. 35B, 12/12 embryos). Dead end knock-down PGCs ( $d n d-\mathrm{MO})$ never showed positive staining for activated caspases at any developmental stage we investigated (e.g. $6 \mathrm{hpf}$, Fig. 3-5B). dnd-MO injected embryos showed fragmented PGCs at $20 \mathrm{hpf}$ however positive caspase activity could not be detected in these cells (data not shown, 14/14 embryos). Thus, as the assay we employed was functional in somatic cells but not in $d n d$-MO or $\alpha$-amanitin treated PGCs we conclude that the PGCs did not activate caspases to undergo cell death. 

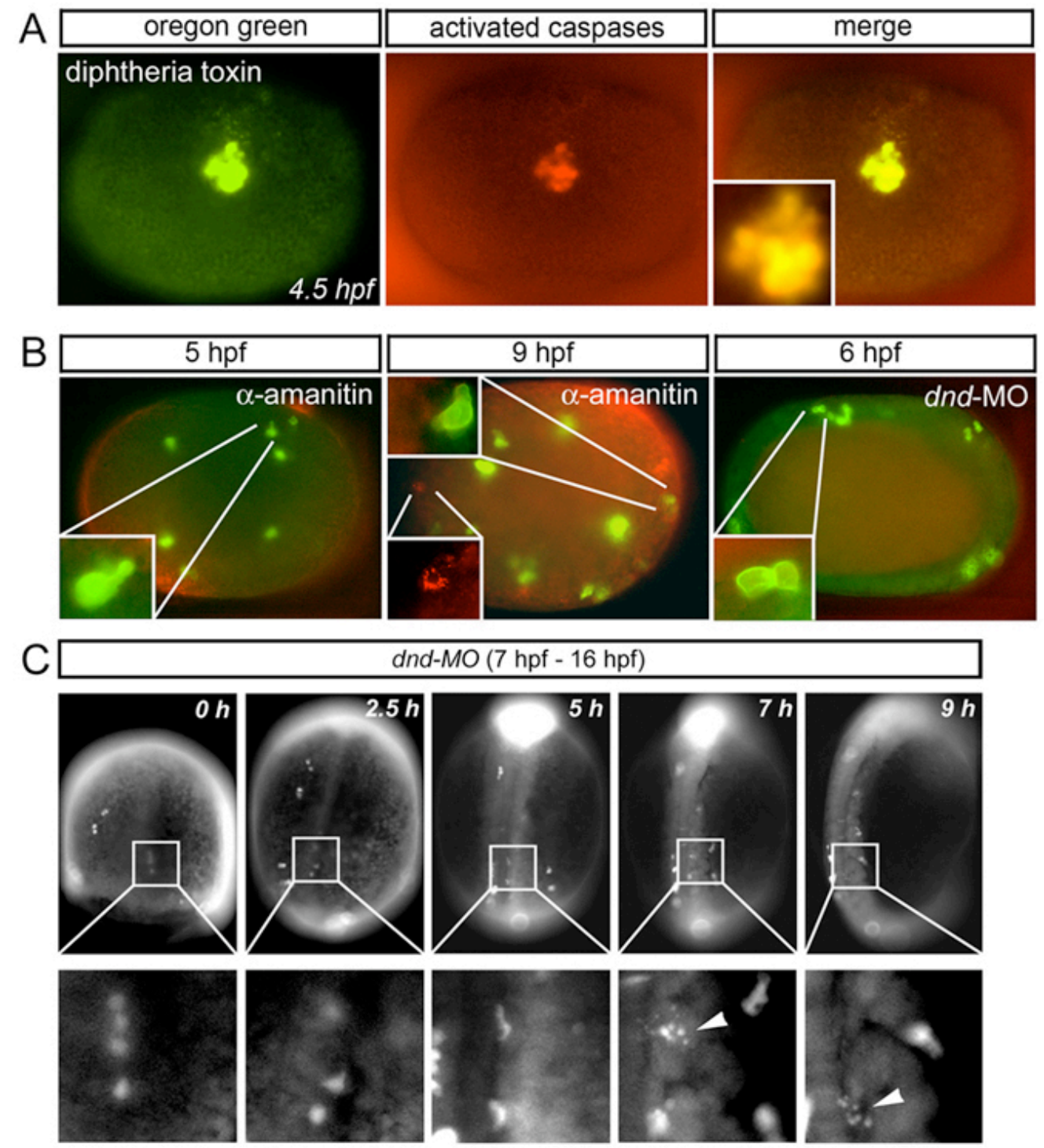

Fig. 3-5. PGCs do not activate caspases before undergoing cell death and PGCs lacking Dead end function die during somitogenesis stages. (A) A clone of somatic cells, which expresses diphtheria toxin, shows positive caspase activity at $4.5 \mathrm{hpf}$. (B) In $\alpha$-amanitin treated PGCs activated caspases can not be detected at $5 \mathrm{hpf}$ or $9 \mathrm{hpf}$ (insets show negative PGCs (green) and a positive somatic cell (red)) and $d n d$-MO treated PGCs do not show caspase activity at $6 \mathrm{hpf}$. (C) Low magnification snapshots from a movie showing Dead end depleted PGCs from 7 hpf to 16 hpf. At 14 hpf (about 8 hours after PGCs normally become motile), first signs of PGC death can be observed as cell fragmentation (see magnified boxes in the lower panels). 


\subsection{The level of membranal E-cadherin is modulated during early PGC development}

The segregation of individual cells from the tissues where they originally reside requires alterations in their adhesive properties. Modulations of cell-cell interaction leading to cell detachment and invasion of neighbouring tissues has been shown to promote dispersion of tumour cells and to be essential for morphogenesis during normal development (reviewed in Christofori, 2003; Tepass, 1999; Thiery, 2002; Thiery, 2003). A molecule known to play a critical role in controlling cell-cell adhesion in such biological contexts is the calcium-dependent cell adhesion molecule E-cadherin (Wheelock and Johnson, 2003).

To determine whether changes in E-cadherin distribution could account for the transition in cell behaviour described above, we have assessed the level of the protein on the PGC membrane at the relevant developmental stages. We have considered the possible variability in staining intensity of E-cadherin in PGCs derived from embryos of the same or different stages and normalized this value by presenting it relative to that of an adjacent somatic cell (Fig. 3-6B). Interestingly, at stages at which wild-type PGCs are migratory, a significantly lower level of membranal Ecadherin was observed relative to that detected at pre-migratory stages (Fig. 3-6A,C). Furthermore, the temporal correlation between E-cadherin expression and PGC motility could be extended to cases in which the PGCs were rendered immotile experimentally. As we have previously described, reducing the level of the Dead end protein in the PGCs results in a severe migration phenotype as a result of complete inhibition of cell motility. Consistent with the notion that a reduction in E-cadherin levels is important for PGC motility, we found that in immotile Dead end knockeddown PGCs E-cadherin is not down regulated (Fig. 3-6A, C). Whereas we expressed the alterations in E-cadherin levels as a ratio with the level observed in somatic cells, a similar result is observed when measuring the absolute signal level on the membrane of the PGCs. Although E-cadherin is down regulated on the membrane of PGCs upon onset of migration, its expression persists in the cells as they migrate. This finding is consistent with the idea that similar to PGCs and other cell types in different organisms (Bendel-Stenzel et al., 1998; Dumstrei et al., 2002; Jenkins et al., 2003; Montero and Heisenberg, 2004; Niewiadomska et al., 1999), zebrafish germ cells probably require a certain level of E-cadherin for their proper migration and cell 
morphology. To test this notion more directly, we have forced expressed E-cadherin in the PGCs and monitored their behaviour. Indeed, PGCs forced expressing Ecadherin exhibited a dramatically reduced migration speed with some cells that remain on the spot while extending protrusions in all directions (Fig. 3-6D, E, 4/4 embryos). This cellular behaviour resulted in a large proportion of embryos with cells located in ectopic positions ( $80 \%$ compared with $8 \%$ in the control embryos having 4 or more ectopic PGCs). Overall, 30\% of the PGCs were found in ectopic positions in $22 \mathrm{hpf}$ experimental embryos versus less than 5\% of control RNA injected embryos (Fig. 3-6F,G). This phenotype is milder than that observed when CXCR4b or SDF-1a are knocked down, consistent with the idea that E-cadherin level is important for optimal migration speed rather than cell guidance.

Fig. 3-6. E-cadherin is dynamically regulated during early stages of PGC development. (A) The expression level of E-cadherin protein is altered during early development in wild-type PGCs (top row, blue, the contours of the relevant cells are delineated with white dots), but remains constant in PGCs knocked down for Dead end (bottom row). (B) A graphic representation of the quantitative analysis examining the relative E-cadherin level on PGCs. Regions in PGC and somatic cell membranes were selected for analysis and the average pixel intensity obtained from the PGC membrane (the inner half of the membrane, red) was divided by the average pixel intensity of the somatic cell membrane (the inner half of the membrane, yellow). (C) Wild-type PGCs at $5.3 \mathrm{hpf}$ show significantly reduced Ecadherin levels relative to earlier stages (comparing $5.3 \mathrm{hpf}$ to $3 \mathrm{hpf}$ ). $d n d$-MO treated PGCs showed no such change in E-cadherin levels on the membrane. (D) PGCs in which full length E-cadherin is forced expressed show a strong reduction in cell motility (e.g. the cell marked with the green arrow). The PGCs exhibit extensive non-polarized protrusive activity (high magnification snapshots). (E) PGC migration speed is severely reduced compared with wild-type PGCs. (F) Embryos forced expressing Ecadherin (122 embryos examined) in PGCs show 30\% ectopic germ cells in comparison to $5 \%$ of control embryos (120 embryos examined). (G) In 22 hpf embryos in which E-cadherin is forced expressed in the PGCs, ectopic PGCs can be observed (black arrowheads, cells labeled using a GFP probe). $\mathrm{n}$ in $(\mathrm{C})$ and $(\mathrm{E})$ is the number of cells analyzed, the error bars represent the standard error of the mean (s.e.m.), asterisk signifies $\mathrm{P}<0.001$. 


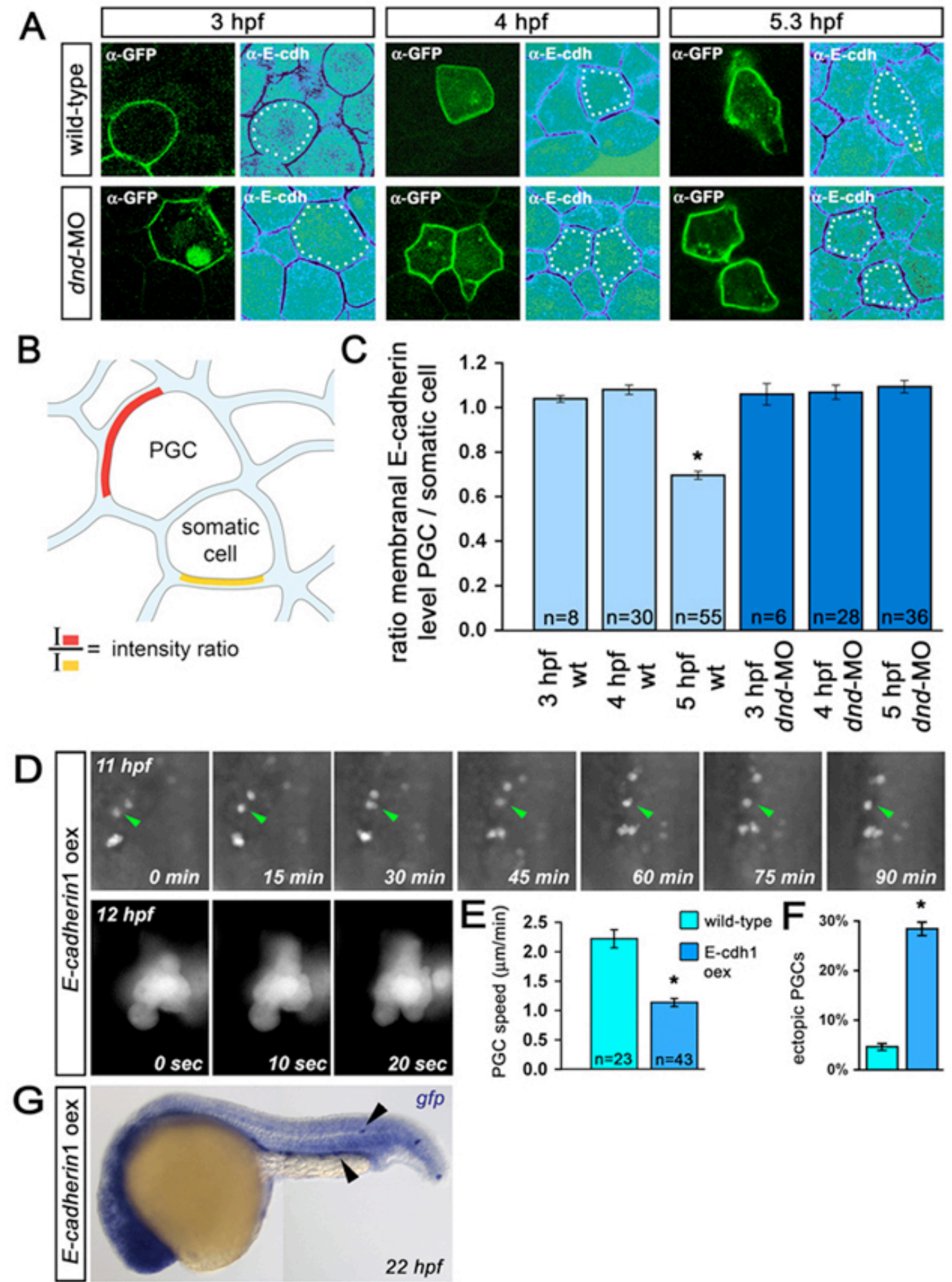

Fig. 3-6. See figure legend on previous page 29. 


\section{$\underline{3.9}$} Acquisition of PGC responsiveness to SDF-1a represents a cellular differentiation step that is temporally distinct from their specification.

The ability to observe PGC behaviour in vivo at the earliest stages of their development allows us to investigate the progression of the cellular response to external cues namely, to SDF-1a, the chemokine that directs PGC migration (Doitsidou et al., 2002). The lack of PGC migration at early stages could result from high levels of SDF-1a expression where they reside similar to the situation found at their intermediate or final targets (Reichman-Fried et al., 2004). Alternatively, this behaviour could reflect an intermediate stage during the cellular differentiation of PGCs at which the cells are not yet capable of responding to directional cues.

Using a combination of RT-PCR and in situ hybridization experiments we have determined that $s d f$-1a is transcribed only zygotically and that the initial uniform distribution of the transcripts is converted into a restricted pattern of expression at 4.7 hpf (data not shown). At this stage, $s d f$-1a is restricted to the blastoderm margin, the position at which the PGCs reside. As the RNA of the SDF-1a receptor, $c x c r 4 b$, is maternally provided (Chong et al., 2001, and data not shown), the PGCs could supposedly respond to SDF-1a upon specification. To determine whether local high concentration of SDF-1a expression is indeed responsible for the lack of cell movement, we inhibited its translation using morpholino antisense oligonucleotides. Significantly, this manipulation had no effect on the early behaviour of the PGCs.

We have subsequently sought to determine the responsiveness of PGCs to SDF-1a at these early stages. To this end, we have transplanted cells overexpressing SDF-1a into embryos whose endogenous SDF-1a activity was inhibited and examined the response of the EGFP-F-labeled PGCs. PGCs exposed to the ectopic SDF-1a source at $3 \mathrm{hpf}$ did not migrate toward the explant for at least 1.5 hours nor did they polarized in the direction of the attractant source (Fig. 3-7A, 4/4 embryos) suggesting that at this stage they lack some components required for responding to the signal. Notably, performing a similar transplantation experiment using older host embryos (older than $4.5 \mathrm{hpf}$ ) led to a rapid response ( 5 minutes after transplantation) of host PGCs that migrated toward the SDF-1a expressing cells (Fig. 3-7B, 9/9 embryos). In control experiments, where the transplanted cells did not express SDF-1a, the PGCs were motile and able to polarize but were not attracted to the explant (Fig. 3-7C, 2/2 embryos). Taken together, these results show that responsiveness to SDF-1a is 
acquired gradually at a late stage that is distinct from that at which PGCs are formed. Furthermore, despite extending protrusions, PGCs remain unresponsive to the chemoattractant and only 1.5 hours later can they initiate chemokine-guided migration. This situation could be considered analogous to that seen in many cell types which express $c x c r 4 b$ (e.g., cells in the somites and along the pronephric duct) yet are indifferent to SDF-1a (Chong et al., 2001; Doitsidou et al., 2002). These are the PGC-specific steps of maturation, culminating in migratory competence, that differentiate these cells from the surrounding CXCR4b-expressing somatic cells. Determining the molecular basis underlying these alterations is likely to provide insights into processes involving similar transitions. For example, the transition observed in PGCs may shed light on the process of epithelial-mesenchymal transition where cells loose their epithelial properties and assume 'amoeboid' invasive migratory behaviour (Savagner, 2001; Thiery, 2002; Thiery and Sleeman, 2006).

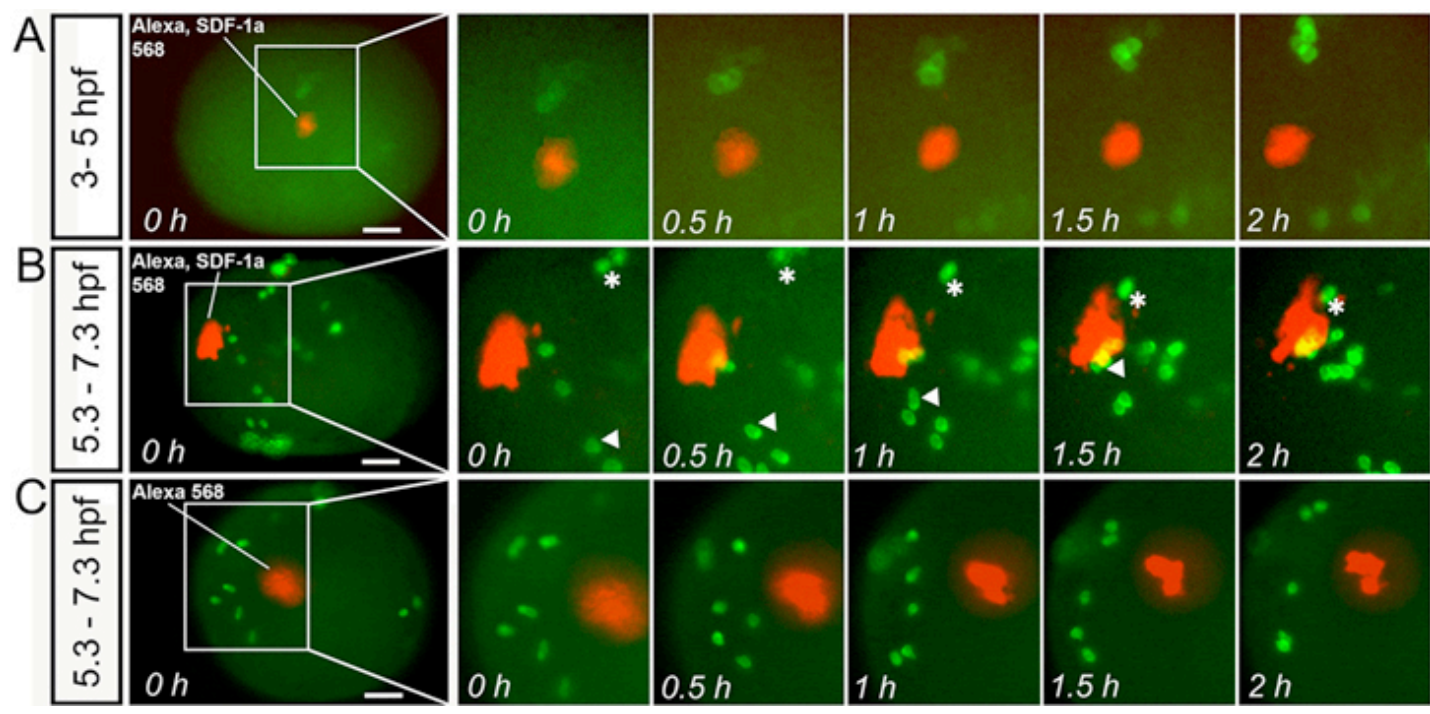

Fig. 3-7. The progression of PGC responsiveness to SDF-1a. (A) PGCs (green) do not respond to SDF-1a expressed by transplanted cells (red), from the time of their specification until 4.5 hpf. (B) At $5.5 \mathrm{hpf}$, the PGCs (green) migrate actively towards the SDF-1a expressing transplant (red) and remain in close proximity to it. Two PGCs migrating toward the SDF-1a source are marked with an asterisk and an arrowhead. (C) A control experiment shows that migrating PGCs (green) remain indifferent to transplanted cells (red) that do not express SDF-1a. The images were obtained from time-lapse movies generated for each experiment. The white scale bar represents $100 \mu \mathrm{m}$.

These results suggest that SDF-1a function is dispensable for zebrafish PGC specification and motility, but is crucial for their directed migration (Doitsidou et al., 
2002). Whereas a number of effector protein have been suggested to function downstream of CXCR4 in different cell types including in zebrafish PGCs (Chalasani et al., 2003; Fernandis et al., 2004; Ganju et al., 1998; Vicente-Manzanares et al., 2002) the precise mechanisms translating the SDF-1 signal into cell polarization and directed migration are currently unknown. Below, the findings concerning molecular mechanisms governing PGC polarization and migration will be presented.

\subsection{PGCs exhibit increased calcium levels in their protrusions, an increase that depends on CXCR4b signalling.}

One of the earliest responses to CXCR4 activation is an increase in calcium levels, thus raising the option that calcium serves as a second messenger transmitting the SDF-1 signal. To determine the distribution of calcium in the PGCs we have loaded the cells with the calcium sensitive dye Oregon green BAPTA (Molecular Probes) by injection at the one-cell stage. Interestingly, we found that the level of free

intracellular $\mathrm{Ca}^{2+}$ was significantly higher in cellular protrusions than in other regions of the cell where no protrusive activity was observed (Fig. 3-8A).

To determine whether this phenomenon depends on SDF-1 signalling, we examined the $\mathrm{Ca}^{2+}$ levels in protrusions of PGCs knocked down for CXCR4b or SDF1a activity. Both manipulations led to a significant reduction of free $\mathrm{Ca}^{2+}$ in protrusions as compared with wild-type control PGCs (Fig. 3-8B,F). Importantly, during directional migration wild-type PGCs display high intracellular $\mathrm{Ca}^{2+}$ at the leading edge whereas CXCR4b knock-down PGCs exhibited comparatively modest elevations of $\mathrm{Ca}^{2+}$ at the leading edge during their non-directional migration (Fig. 3$8 \mathrm{E}$, and data not shown). Notably, calcium is the first characterized polarized indicator in PGCs undergoing guided migration so far.

To investigate the significance of these transient $\mathrm{Ca}^{2+}$ elevations in protrusions and particularly at the leading edge of directionally migrating PGCs, we buffered calcium elevations by expressing calcium-binding proteins in the germ cells to see whether we could manipulate $\mathrm{Ca}^{2+}$ levels in the PGCs. Two well-known proteins, parvalbumin and calbindinD28k, act as 'calcium-buffers' in neuronal cells (Chard et al., 1993). 
A

B

$0 \mathrm{~s}$

$10 \mathrm{~s}$

$20 \mathrm{~s}$

$30 \mathrm{~s}$
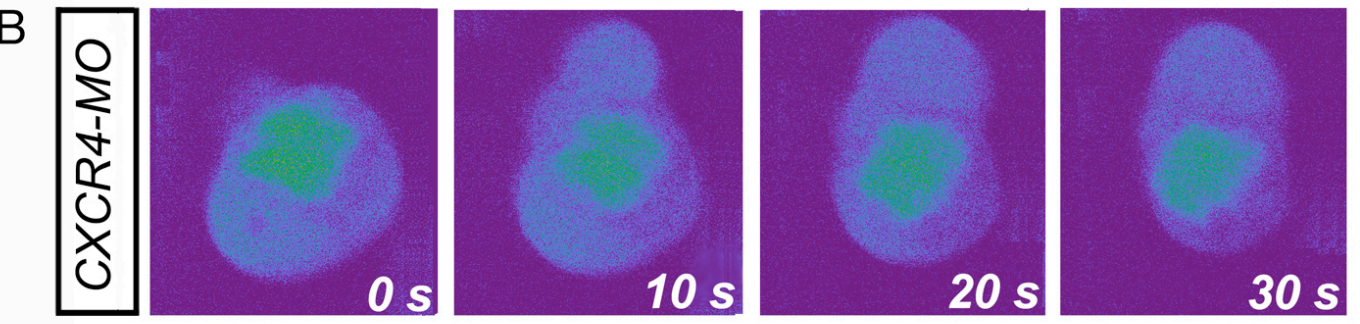

C
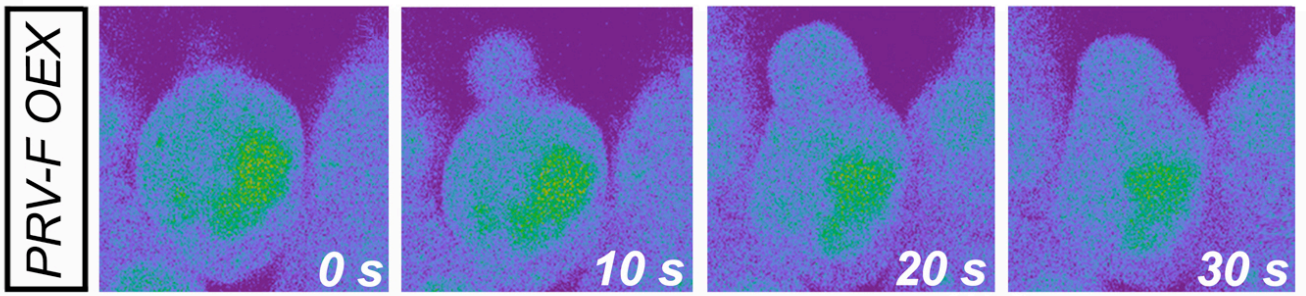

D
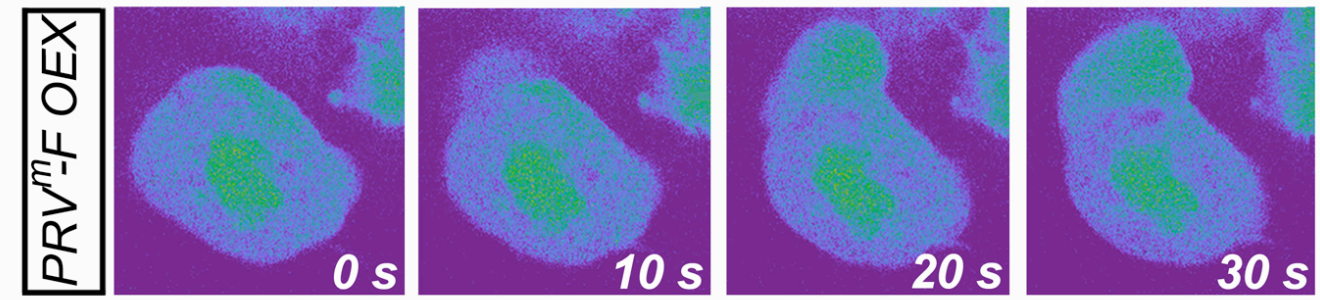

E
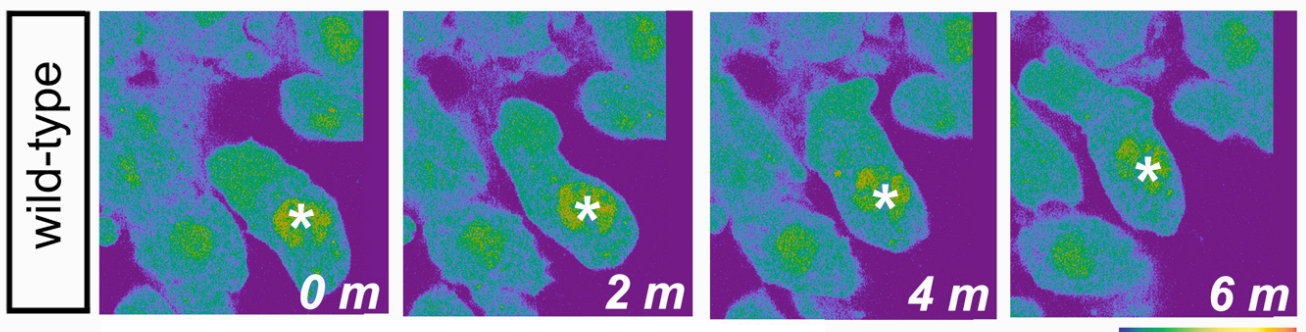

F

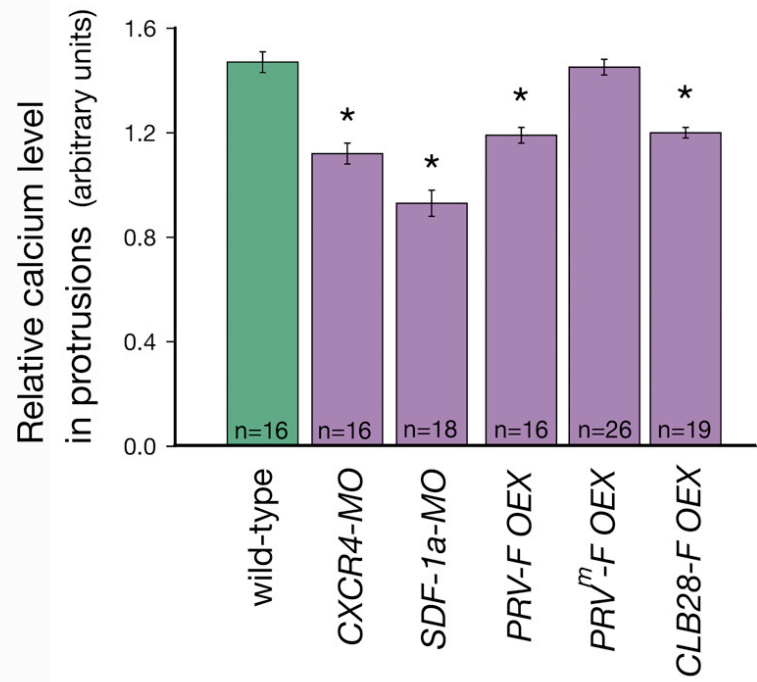

$\left[\mathrm{Ca}^{+2}\right] \Rightarrow$ 
Fig. 3-8. Reduced Calcium levels in the front of migratory PGCs lacking CXCR4b. (A-D) Snapshots from high magnification time-lapse movies obtained at $10 \mathrm{sec}$ intervals by using confocal microscopy. (A) Wild-type PGCs (pseudocolor) loaded with Oregon Green BAPTA 488 show high calcium levels in forming protrusions. (B) PGCs lacking CXCR4b show obviously reduced free calcium levels in protrusions. (C) The over expression of a membrane bound calcium buffering protein (farnesylated parvalbumin $=$ PRV-F) specifically in PGCs lowered the calcium levels in protrusions. (D) The over expression of membrane bound mutated parvalbumin ( $\mathrm{PRV}^{\mathrm{m}}-\mathrm{F}$, calcium binding domains are non functional) specifically in PGCs did not change the calcium levels in protrusions. (E) The images ( 2 min intervals) were obtained from time-lapse movies generated by confocal microscopy. Wild-type PGCs display higher calcium at the leading edge versus the rear of the cell during directional migration. One representative PGC is highlighted with an asterisk. (F) Summary of the results from A$\mathrm{D}$; relative calcium levels in protrusions versus the nuclear signal divided by factor two. $\mathrm{n}$ - number of cells observed, asterisk $-\mathrm{P}<0.001$ (error bars: standard error of the mean, s.e.m.)

Indeed, expression of membrane bound parvalbumin or calbindinD28k in PGCs lowered the intracellular free $\mathrm{Ca}^{2+}$ levels in protrusions (Fig. 3-8C,F). Conversely, the expression of the calcium binding deficient mutant form of parvalbumin did not alter the $\mathrm{Ca}^{2+}$ levels in protrusions significantly (Fig. 3-8D,F). Thus, the decreased $\mathrm{Ca}^{2+}$ level in PGCs expressing parvalbumin arises from the specific function of this calcium binding protein to buffer extensive calcium elevations.

These findings provided us with a useful tool to determine the role of calcium levels in PGC migration by monitoring this process in germ cells in which calcium elevations in the leading edge are buffered.

\subsection{Alteration of calcium levels in PGCs affect their migration behaviour.}

As mentioned above, we could significantly lower free intracellular $\mathrm{Ca}^{2+}$ levels in PGCs by expressing plasma membrane bound calcium binding proteins (Fig. 3-8). As we monitored the behaviour of such germ cells in live zebrafish embryos, we found that PGCs migrated abnormally such that some cells arrived at ectopic locations already at $10 \mathrm{hpf}$ with the severity of the migration phenotype gradually increasing during the first day of development (Fig. 3-9B). Consequently, at $23 \mathrm{hpf}$ about 30\% of all germ cells were located at ectopic positions such as in the somites, along the yolkextension, the head as well as at random positions in the yolk (Fig. 3-9B). 


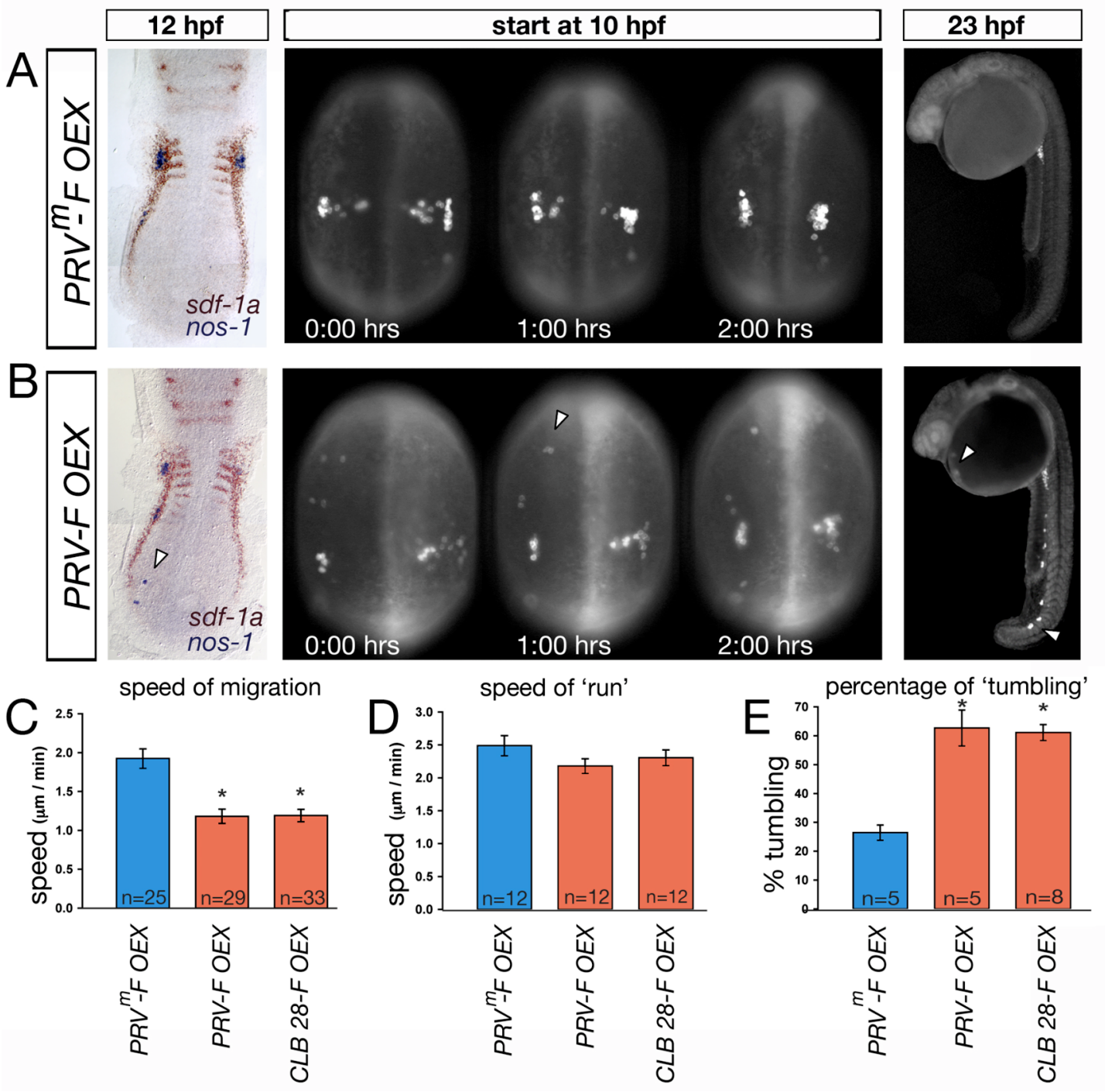

Fig. 3-9. Calcium buffering in PGCs leads to aberrant migratory behaviour. (A) Over expression of membrane bound mutant parvalbumin in PGCs. The picture on the left shows in situ hybridization staining of $s d f-1 a$ (red) and the PGC marker nos- 1 at $12 \mathrm{hpf}$. In the middle, snapshots of a representative low magnification movie depict the migration path of PGCs from $10-12 \mathrm{hpf}$. At $23 \mathrm{hpf}$, PGCs reached their target area. (B) Over expression of membrane bound functional parvalbumin in PGCs. The picture on the left shows in situ hybridization staining of $s d f-1 a$ (red) and the PGC marker nos-1 at $12 \mathrm{hpf}$, where ectopic PGCs are depicted with an arrowhead. In the middle, snapshots of a representative low magnification movie display the migration path of PGCs from $10-12$ hpf. An ectopic localized PGC is marked with an arrowhead. At $23 \mathrm{hpf}$, several PGCs did not reach their target area and are found in ectopic positions within the entire embryo (see arrowheads). (C) Over expression of membrane bound calcium buffering protein (farnesylated parvalbumin $=$ PRV-F or farnesylated calbindinD28k = CLB28-F) specifically in PGCs reduced their speed of migration in comparison to the control experiment ( $\mathrm{PRV}^{\mathrm{m}}$-F, calcium binding domains are non functional). (D) The speed of 'run' did not significantly change among different experiments. (E) Over expression of PRV-F or CLB28-F results in significant prolonged residence in the 'tumbling' phase. $\mathrm{n}$ - number of cells observed, asterisk $-\mathrm{P}<0.001$ (error bars: standard error of the mean, s.e.m.) 
Importantly, in situ hybridization analysis confirmed the specificity of the treatment as experimental embryos exhibited normal SDF-1a expression pattern similar to control embryos (Fig. 3-9A,B). Thus somatic development was unaffected by these manipulation strongly suggesting that the migration phenotype resulted from the alterations in calcium distribution in the PGCs.

To determine the basis for the defective migration we analyzed the migration of the germ cells by monitoring the migration speed (includes 'run' and 'tumbling' phases), the speed during 'run' phases and the total time spent in either 'run' or 'tumbling' phases. PGCs expressing functional parvalbumin or calbindinD28k exhibited a reduced speed of migration as compared with germ cells expressing the non-functional mutated form of parvalbumin (Fig. 3-9C). Nevertheless, these PGCs were actively migrating and were able to polarize similar to control PGCs (data not shown). Surprisingly, the speed during 'run' phases did not change significantly by buffering calcium. It was however the time spent in the 'tumbling' phases that was dramatically increased in experimental PGCs (Fig. 3-9D,E). Therefore, the reduced migration speed of PGCs expressing functional calcium binding proteins resulted from the prolonged duration spent in 'tumbling' phases.

\subsection{STIM1 triggered store-operated $\mathrm{Ca}^{2+}$ influx promotes protrusive $\underline{\text { activity in PGCs }}$}

The findings that calcium levels were increased at the leading edge and in forming protrusions coupled with the demonstration that this increase is important for normal PGC migration prompted us to examine the effect of the reverse manipulation. Recently, two proteins, STIM1 and STIM2 (stromal interaction molecule), have been implicated to be required for $\mathrm{Ca}^{2+}$-store-depletion-mediated $\mathrm{Ca}^{2+}$ influx (Liou et al., 2005; Oritani and Kincade, 1996; Roos et al., 2005; Sabbioni et al., 1997, Williams et al., 2001; Zhang et al., 2005). Sensing low calcium levels in the endoplasmatic reticulum (ER), these proteins translocate to the plasma membrane where they induce $\mathrm{Ca}^{2+}$ influx by interacting with calcium channels. Importantly, a specific mutation in the STIM1 protein (STIM1-D76A) leads to a constitutive action in promoting calcium influx (Liou et al., 2005; Zhang et al., 2005). 
First, we have cloned the corresponding zebrafish gene stim 1 to observe its expression in the zebrafish embryo. stiml RNA is ubiquitously and uniformly expressed in zebrafish embryos from the one-cell stage until somitogenesis stages (Fig. 3-10). This expression pattern led to the assumption that PGCs express stiml RNA during their migration phases.

To determine whether mammalian STIM1 protein exhibit the same localization behaviour in zebrafish PGCs as it was previously described for other cell types (Liou et al., 2005; Zhang et al., 2005), we have fused the DsRed ORF with the mouse STIM1 gene and followed the distribution of the fusion-protein in migrating germ cells.

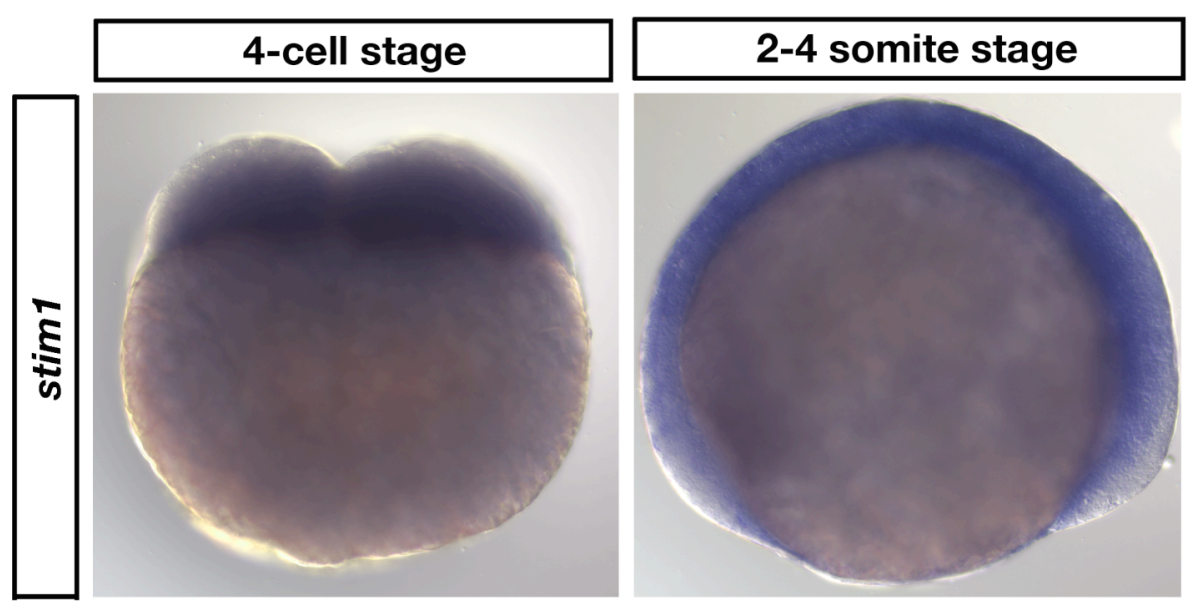

Fig. 3-10. Zebrafish stim1 RNA expression pattern. RNA in situ hybridization of stiml shows maternal uniform expression at the 4-cell stage. stim 1 is ubiquitously expressed during somitogenesis (here 2-4 somite stage).

Indeed, as previously described the wild-type mouse STIM1 (STIM1) protein was primarily localized to the ER and was rarely seen at the plasma membrane. In contrast, the mutant form of mouse STIM1 (STIM1 ${ }^{\mathrm{M}}$ lacking the $\mathrm{Ca}^{2+}$-sensor ability because of mutated EF-hand = STIM1-D76A/D77A) was predominantly localized to the plasma membrane at the rear off the cell (Fig. 3-11A,B STIM1/ER co-localization data not shown).

PGCs expressing STIM1 ${ }^{\mathrm{M}}$ exhibited abnormal extensive protrusive activity primarily at the sites where STIM1 ${ }^{\mathrm{M}}$ was localized (Fig. 3-11B,C, membrane and puncta). This effect was observed locally (e.g. back of the cell) or globally depending on the distribution of the mutant STIM1. 

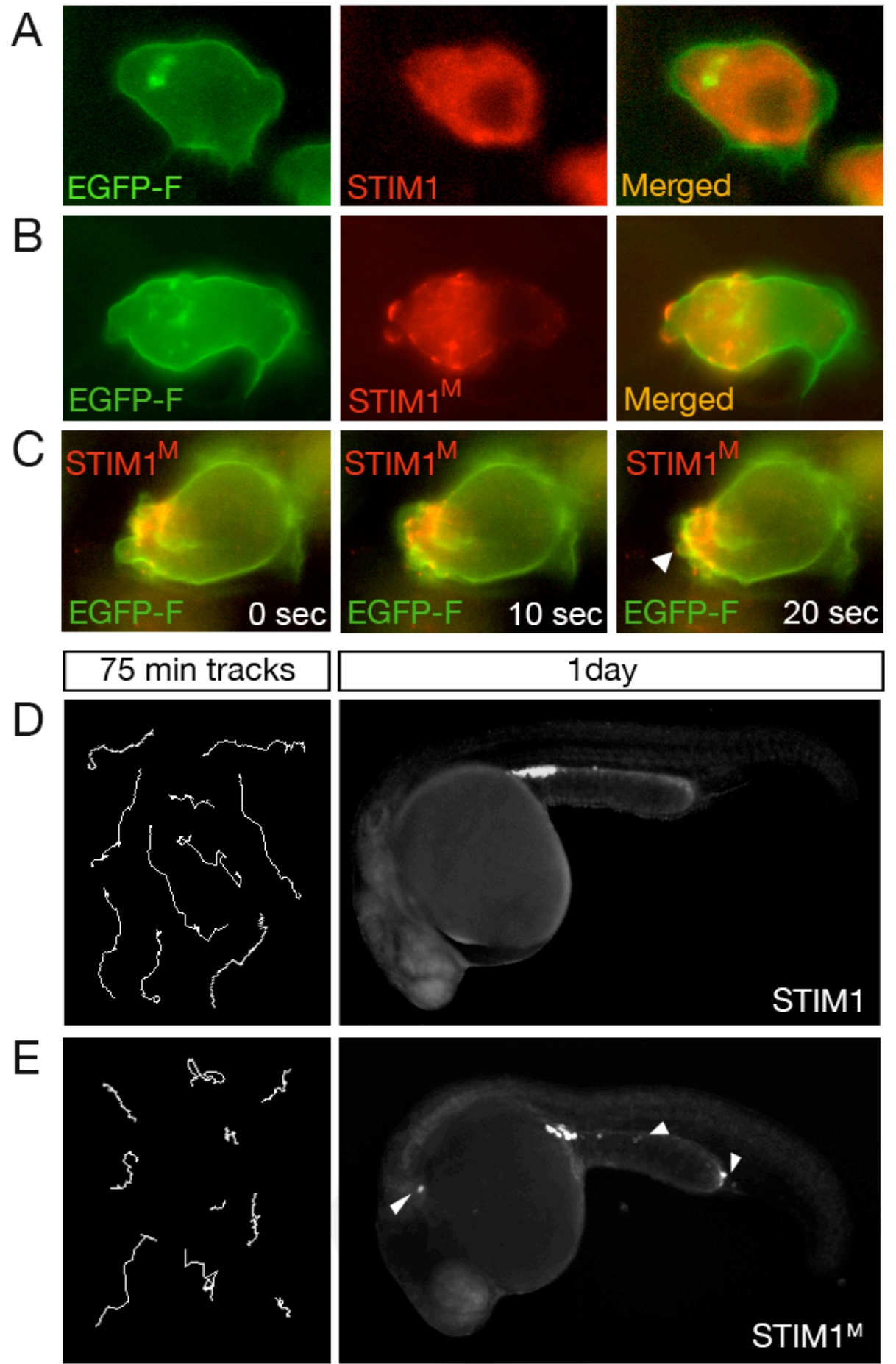

E

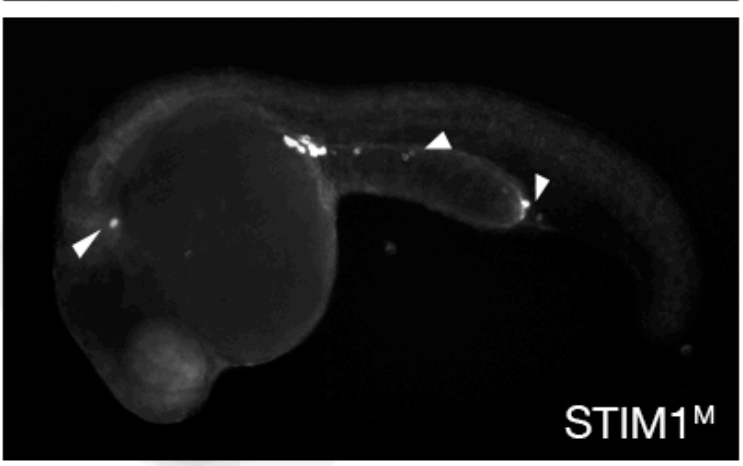

F migration speed
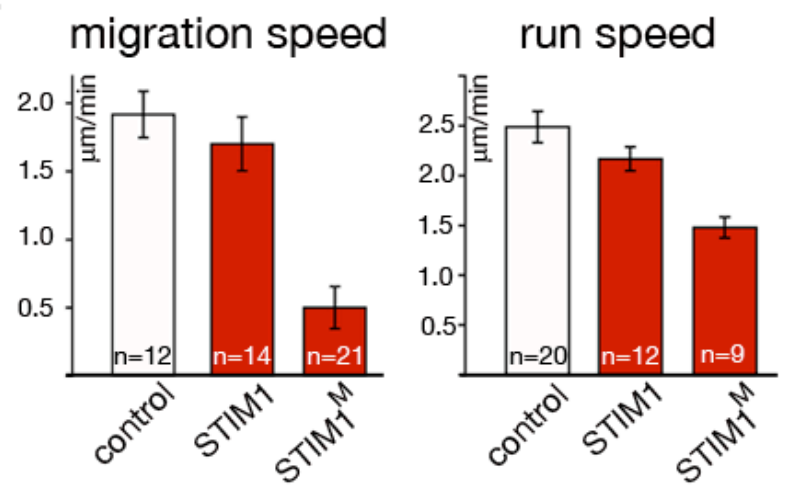

tumbling

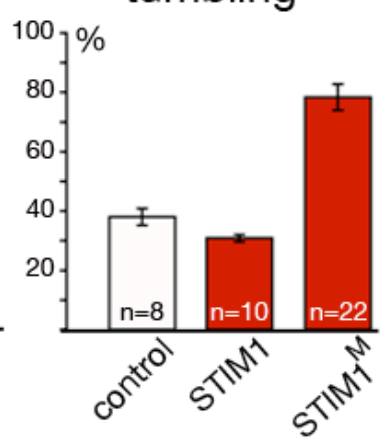


Fig. 3-11. Mutated STIM1 increases protrusive activity of PGCs and interferes with their normal migration behaviour. (A) Wild-type form of STIM1 (STIM1 $300 \mathrm{pg}$, red) does co-localize with the ER but not with the plasma membrane (green) of migratory PGCs. (B) Mutated STIM1 (STIM1 ${ }^{\mathrm{M}} 300$ pg, red) is preferentially localized to the plasma membrane (green) of germ cells. (C) PGCs expressing $\mathrm{STIM}^{\mathrm{M}}$ (red) show extensive protrusive activity primarily where $\mathrm{STIM} 1^{\mathrm{M}}$ is localized (white arrowhead). (D) 75 min tracks of PGCs expressing STIM1 show 'normal' migration behaviour. PGCs expressing STIM1 are found at the usual position after 1 dpf. (E) 75 min tracks of PGCs expressing $\mathrm{STIM}^{\mathrm{M}}$ represent the diverse complex migration behaviour of those cells. Some PGCs expressing $\mathrm{STIM}^{\mathrm{M}}$ are found in ectopic positions in the embryo after $1 \mathrm{dpf}$ (white arrowheads). (F) Analysis of the different migration parameters of PGCs expressing control RNA, STIM1 and STIM1 ${ }^{\mathrm{M}}$. $\mathrm{n}$ - number of cells observed, error bars $=$ standard error of the mean, s.e.m.

Interestingly, newly forming protrusions displayed STIM1 ${ }^{\mathrm{M}}$ only on their tips further linking calcium levels to protrusion formation.

The migration path of STIM1 ${ }^{\mathrm{M}}$-expressing PGCs revealed that these cells cover less distance during 75 min than STIM1-expressing germ cells thus they migrate slower. In addition, the shape of the tracks suggests that PGCs expressing $\mathrm{STIM}^{\mathrm{M}}$ show less persistence in their directional migration (Fig. 3-11E). These alterations in PGC migration behaviour led to the phenotype observed after $1 \mathrm{dpf}$ when on average $38 \%$ of PGCs (23/27 embryos observed) were located in ectopic locations (Fig. 3-11E). A detailed analysis of the migration behaviour of PGCs expressing $\mathrm{STIM}^{\mathrm{M}}$ revealed that the speed of migration was severely reduced in comparison to wild-type STIM1 expressing germ cells. Specifically, PGCs expressing $\mathrm{STIM}^{\mathrm{M}}$ were significantly slower during their 'run' phases. This behaviour might be due to the abnormal formation of protrusions seen on the back and sides of the cells, thus interfering with normal polarized migration. In addition, germ cells expressing $\mathrm{STIM}^{\mathrm{M}}$ remain for an abnormally long period of time in 'tumbling' phases, which may reflect a defect in establishing or maintaining cell polarity (Fig. 3-11F). Thus, local $\mathrm{Ca}^{2+}$ elevations might be important to establish cellular polarity and trigger the formation of protrusions in PGCs. $\left[\mathrm{Ca}^{2+}\right]_{\mathrm{i}}$ gradients regulate many fundamental molecular processes crucial for cell migration including the formation of actomyosinbased contractile forces, the regulation of F-actin structures and dynamics as well as the assembly and disassembly of cell-substratum adhesions (Sjaastad and Nelson, 1997). 


\subsection{MLCK localized to the leading edge of PGCs activates its downstream effector MLC.}

In non-muscle cells, contractility of actomyosin network is regulated by the phosphorylation level of the motor protein myosin II. Myosin II consists of two heavy chains, (MHCs, contains ATP-binding sites in the globular motor domains and a domain for interaction with F-actin) and two myosin II regulatory light chains (MRLC or MLC). The phosphorylation of MLC allows the myosin II motor protein to bind F-actin therefore exerting its function to create contractile forces. The extent of MLC phosphorylation depends primarily on the balance between the activity of two enzymes, the $\mathrm{Ca}^{2+} /$ calmodulin-dependent MLC kinase (MLCK), and the MLC phosphatase (MLCP).
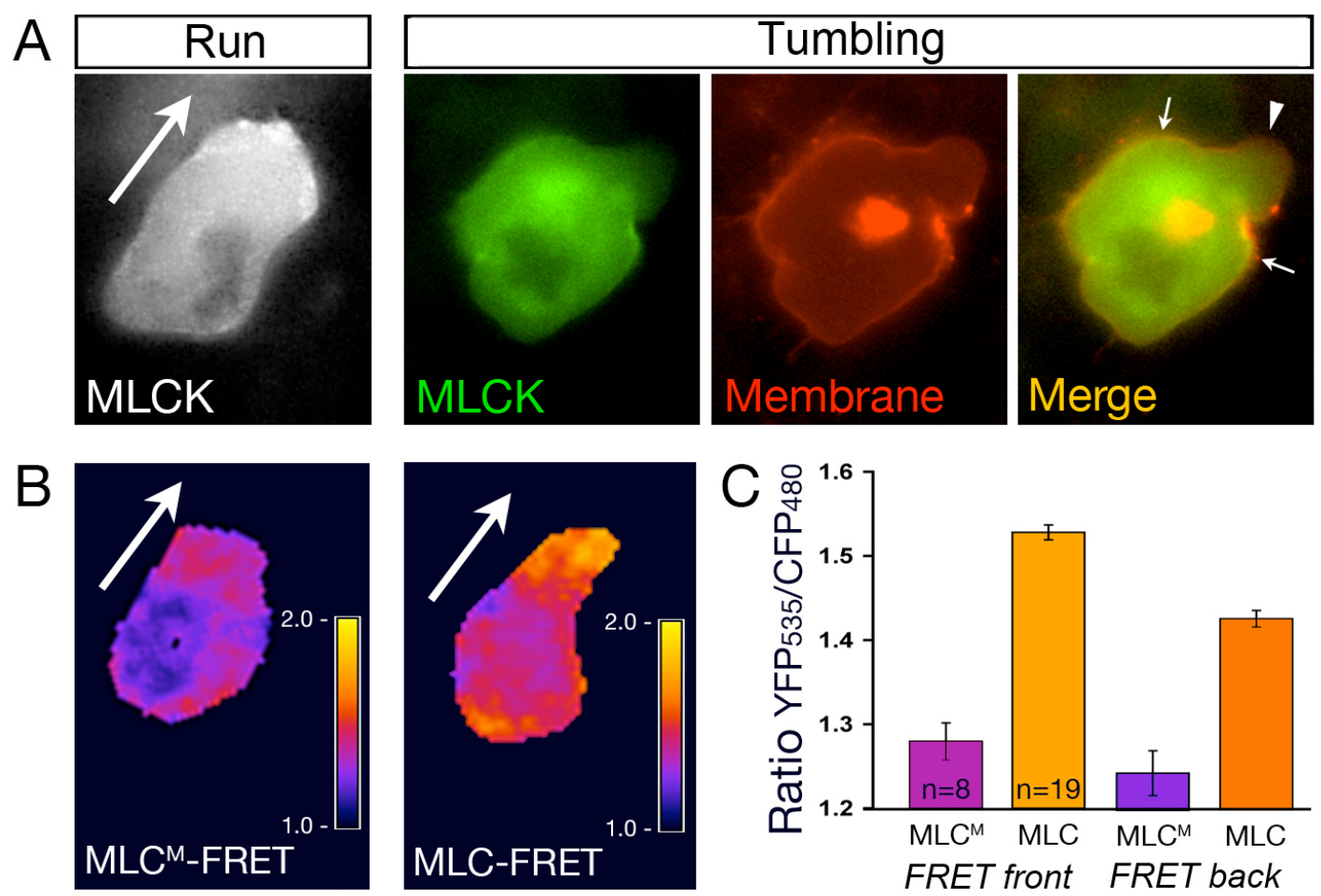

Fig. 3-12. MLCK at the leading edge mediates MLC activation upon phosphorylation. (A) Directional migrating PGC has MLCK localized to the leading edge. Some MLCK is also localized to the plasma membrane on the sides and the back during migration. White arrow points to direction of migration. The merge image of MLCK (green) and plasma membrane (red) shows co-localization (white arrows) except at the time a new protrusion forms (white arrow-head). (B) MLC activation in the front and at the back of a directional migrating PGC. The non-activateable MLC ${ }^{\mathrm{M}}$ exhibit no activation during PGC migration. White arrow points to direction of migration. (C) Diagram of Ratio of $\mathrm{YFP}_{535} / \mathrm{CFP}_{480}$ (FRET signal) illustrates no activation and no significant differences between front and back by using the mutated MLC $\left(M^{2} C^{\mathrm{M}}\right)$ versus functional MLC. $\mathrm{n}$ - number of PGCs analyzed. 
To determine the localization of MLCK in migrating PGCs we examined the distribution of an MLCK fluorescent fusion protein. MLCK was clearly localized to the leading edge of directionally migrating germ cells and was found at much lower levels at the back of the cell (Fig. 3-12A, run). MLCK was found to co-localize with membranal DsRed protein except when protrusions were newly formed (Fig. 3-12A, tumbling). Thus, the MLCK localization on the plasma membrane might reflect the co-localization with the actin-cortex where myosin II mediates the contractility of the cortex. In conclusion, MLCK activity might be preferentially needed in the leading edge of migrating PGCs to activate myosin II thereby controlling the degree of contractility and formation of front protrusions.

Consistent with this idea, we observed high activation levels (FRET signal) of MLC in the front of migrating PGCs and slightly less and spatially more restricted activity in the back. A control non-activateable MLC reporter gene $\left(\mathrm{MLC}^{\mathrm{M}}\right.$, mutated MLCK phosphorylation sites, (Yamada et al., 2005) showed very low FRET signal, with no significant difference between the front and the back (Fig. 3-12B,C).

\subsection{Regulated MLCK and DAPK activity is crucial for normal PGC migration.}

Differential contraction of actomyosin mediated by varying degrees of MLC phosphorylation has been shown to be important for the migration behaviour in various cell types (Affolter and Weijer, 2005; Brown and Bridgman, 2003; Brown and Bridgman, 2004; Parent, 2004; Schmidt et al., 2002; Somlyo et al., 2000). In addition to MLCK, other kinases have been implicated in direct phosphorylation and thereby activation of MLC. For example, the death-associated protein kinase (DAPK is calcium dependent) can activate MLC and was shown to play a role in tumor cell invasion and cell polarity (reviewed in Kuo et al., 2006; Shohat et al., 2002).

The RNAs encoding for MLCK and DAPK are ubiquitously and uniformly expressed at the 4-cell stage (maternally provided transcripts) and at the 2-4 somite stages, which indicates that in principal, PGCs express those kinases during their migration (Fig. 3-13). 


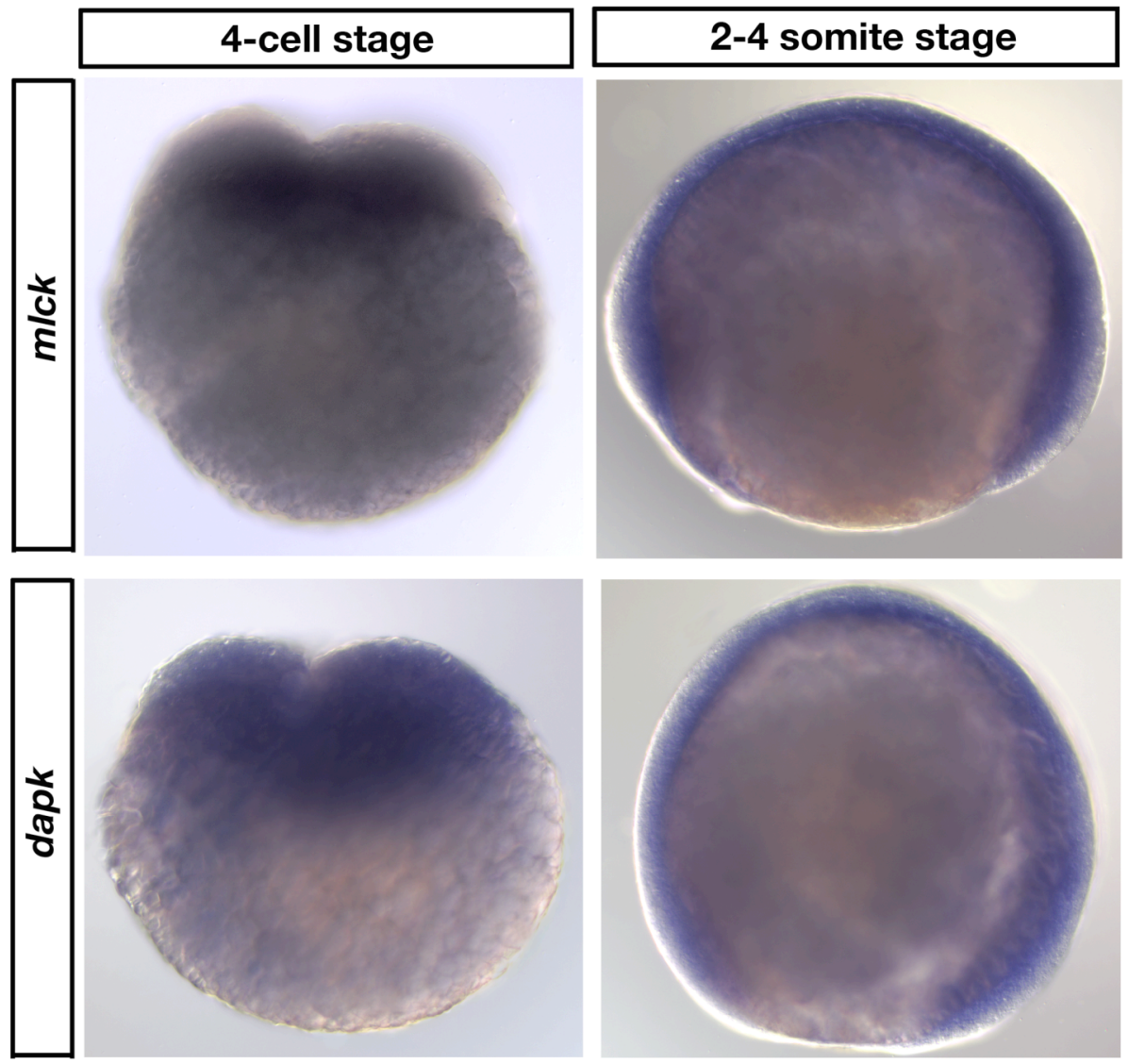

Fig. 3-13. Zebrafish mlck and dapk RNA expression pattern. RNA in situ hybridizations of $m l c k$ and dapk show maternal uniform expression at the 4-cell stage. Both, mlck and dapk are ubiquitously expressed during somitogenesis (here 2-4 somite stage).

To determine whether MLCK and/or DAPK could be involved in controlling the migration behaviour of zebrafish PGCs, we expressed the constitutively active and dominant negative forms of these potential MLC activators in the germ cells. Overexpression of the constitutively active MLCK (CA-MLCK, deletion mutant missing the $\mathrm{Ca}^{2+} /$ calmodulin regulatory binding site and the auto-inhibitory domain leads to a substantial increase in basal level of MLC phosphorylation, (Wadgaonkar et al., 2003)) resulted in an increased protrusive activity in PGCs. Specifically, those cells sent mainly broad protrusions in random directions and often the protrusions were of a large size and continued to expand or spun in a clockwise or anti-clockwise direction, (Fig. 3-14B). Interestingly, a similar PGC behaviour could be observed when constitutively active DAPK (CA-DAPK) was expressed in the germ cells (Fig. 3-14D). Thus, CA-MLCK and CA-DAPK presumably increased the amount of MLC activation and subsequently the excess of myosin contraction resulted in the formation of broad or 'spinning' protrusions. The establishment of such abnormal protrusions 
might be due to myosin contractions at positions that do not normally generate contractile forces leading to the increased size of the protrusion.

On the other hand, PGCs expressing dominant negative forms of MLCK or DAPK (DN-MLCK, DN-DAPK) displayed a non-polarized large number of protrusions of different sizes and the majority of these processes was smaller in size compared with the protrusions of wild-type or constitutively active MLCK treated PGCs (Fig. 3-14C,E). Consistent with the strong morphological cellular phenotype, PGCs with altered MLCK or DAPK activity showed shortened migration tracks that culminated in germ cells found in ectopic positions in the embryo (Fig. 3-14B-E). In addition, PGCs in which MLC kinase activity was altered exhibit normal or slightly reduced 'run' speed but encounter severe problems in polarization and alternating between 'run' and 'tumbling' phases (Fig. 3-14F).

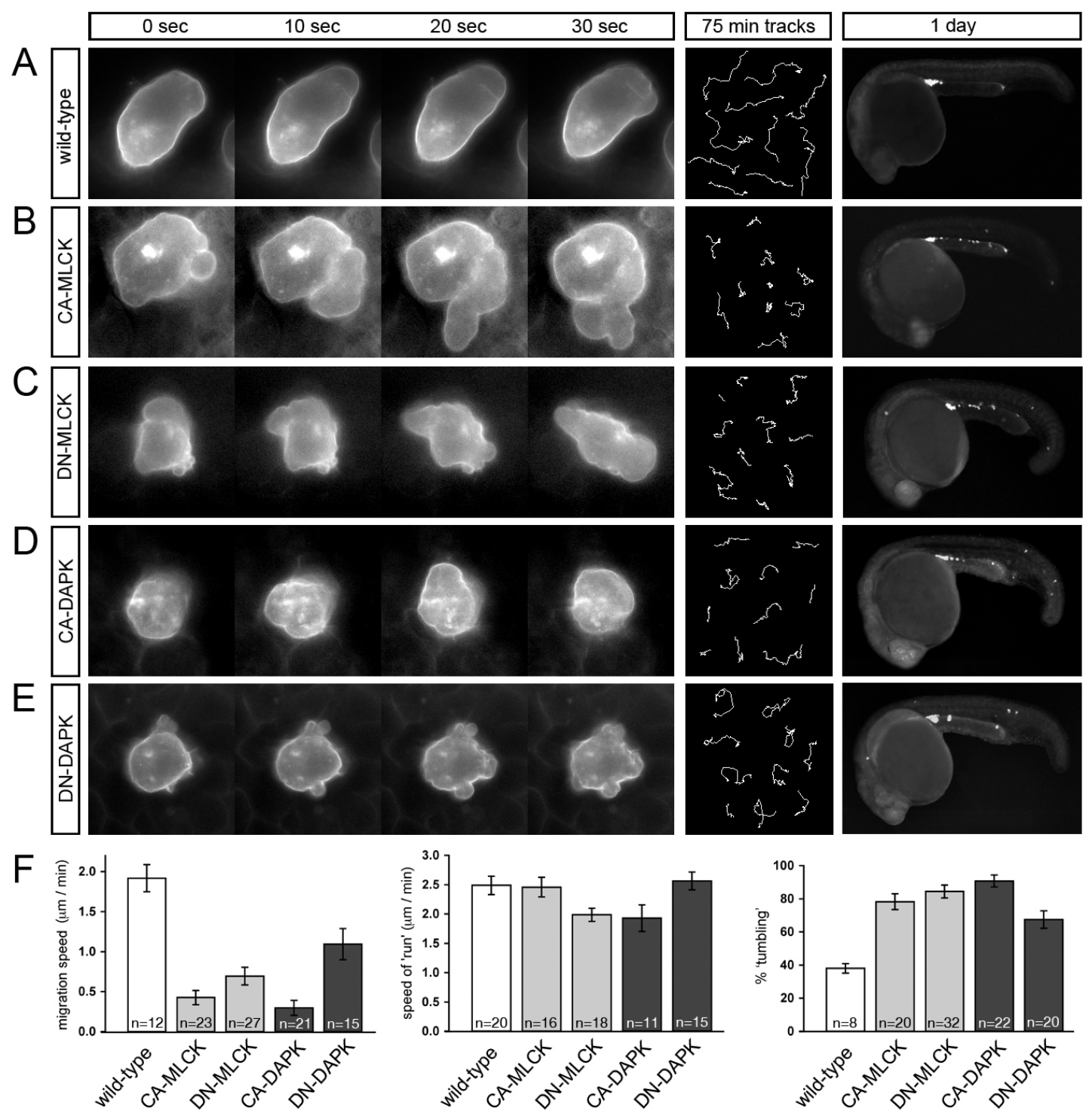


Fig. 3-14. Alterations of MLC kinase activity leads to aberrant PGC morphology and migration behaviour. (A-E) Snapshots from high magnification time lapse movies. The tracks represent $75 \mathrm{~min}$ PGC migration pathways. Some PGCs expressing mutant forms of MLCK or DAPK are located in ectopic positions compared to wild-type PGCs (min. 20 embryos considered per experiment). (A) Wild-type PGCs show elongated polarized migration, protrusions primarily at the leading edge. (B) PGC expressing constitutively active MLCK displays big protrusions and executes 'spinning'. (C) Dominant negative MLCK causes the formation of a high variety of protrusions. (D) PGC expressing constitutively active DAPK displays broad protrusions and performs 'spinning'. (E) Dominant negative DAPK causes extensive blebbing in random directions. (F) PGCs expressing mutant forms of MLCK or DAPK show alterations in migration behaviour. $\mathrm{n}=$ number of cells analyzed, error bar $=$ standard error of the mean - s.e.m.

In conclusion, properly localized activity of MLCK and/or DAPK are likely to be crucial for proper PGC polarity and formation of a proper size of protrusions required for establishing and maintaining the leading edge during migration. 


\section{$4 \quad$ Discussion}

\subsection{Cellular Mechanisms of PGC differentiation}

The results presented in this work demonstrate that following their specification, zebrafish PGCs undergo a string of distinct differentiation steps that culminate in their migration (summarized in Fig. 4-1). This description of the onset of zebrafish PGC migration may represent a general behaviour of cells before they become migratory. The finding that early zygotically-transcribed genes and those whose function is regulated by the Dead end protein are essential for PGC transition from non-motile to directionally migrating cells should allow focusing the search on the specific molecules involved in this process. Considering that in the absence of Dead end protein, PGCs do not polarize and never obtain migratory behaviour, a sound strategy for identifying these molecules would be to use Dead end as a tool. Isolating RNA molecules that interact with the RNA binding protein Dead end is likely to uncover genes that play a role in the transition of PGCs to guided active migration.

As PGCs in different organisms appear to utilize similar molecular pathways for their migration (Molyneaux and Wylie, 2004; Raz, 2004; Santos and Lehmann, 2004), the results described here may be relevant for mouse and Drosophila PGCs, as well. For example, studies of live Drosophila PGCs isolated and cultured in vitro show striking similarities to the behaviour of zebrafish PGCs in vivo; shortly after their specification, cultured Drosophila PGCs are not motile and subsequently, they randomly extend small protrusions followed by pseudopodia formation and cell polarization (Jaglarz and Howard, 1995). Remarkably, neural crest cells delaminating from the neural tube exhibit a behaviour that is qualitatively similar to that described above for zebrafish PGCs early in their development. Here, the cells initially display excessive membrane blebbing that is followed by extension of lamellipodial processes and movement away from the neural tube (Halloran and Berndt, 2003). The step-wise manner by which cells acquire their competence to migrate appears to pertain to abnormally developing cells as well, since a subset of primary tumor cells that can polarize in the direction of blood vessels show increased metastatic potential (e.g., (Wyckoff et al., 2000)). Although this transition phase is an essential first step for cell migration, it is poorly understood at the molecular level. Specification of the 
migratory cell fate in the case of border cells depends on the function of the JAKSTAT pathway (Beccari et al., 2002; Silver and Montell, 2001), while neural crest cell migration depends on proteins of the Snail family (Nieto, 2001). Experiments aimed at identifying molecules controlling such a transition were conducted using microarray-based analysis comparing the transcriptom of metastatic cells with that of non-metastatic cells. In these studies a dramatic up- regulation of genes that are part of the "minimum motility machine" such as genes encoding cofilin, capping proteins and components of the Arp2/3 pathways are observed (e.g., (Wang et al., 2004)). However, the precise role of these proteins in initiating the motile behaviour is not clear. Studying the function of proteins involved in metastasis in the context of zebrafish PGC migration is therefore an attractive avenue for determining the role they play in metastasis and in normal development.

Previous studies of PGC migration have identified CXCR4b and its ligand SDF-1a as the receptor-ligand pair guiding the cells to their targets (Doitsidou et al., 2002). CXCR4b however, is likely to be irrelevant to the control of the initiation of PGC migration. First, cxcr4b RNA is maternally provided ((Chong et al., 2001) and our unpublished results) and thus could not be the limiting factor necessary for the transition to a motile behaviour. It could nevertheless be possible that $c x c r 4 b$ RNA translation could represent a step during early PGC maturation that would provide functional CXCR $4 b$ protein by the time the cells start migrating towards SDF-1a. However, the finding that in the absence of functional CXCR4b, the PGCs actively migrate, albeit non directionally (Doitsidou et al., 2002; Knaut et al., 2003), would argue against this scenario. A more likely group of molecules that could control PGC motility in zebrafish is suggested by the demonstration that the migration speed and cell morphology are controlled by PI3K (Dumstrei et al., 2004). Monitoring the activity of this molecule, the activity of molecules acting downstream of it (e.g., Rho GTPases) and those constituting the "minimum motility machine" during early PGC development is expected to provide an insight into the mechanism underlying the transition from immotile to motile cell behaviour. 


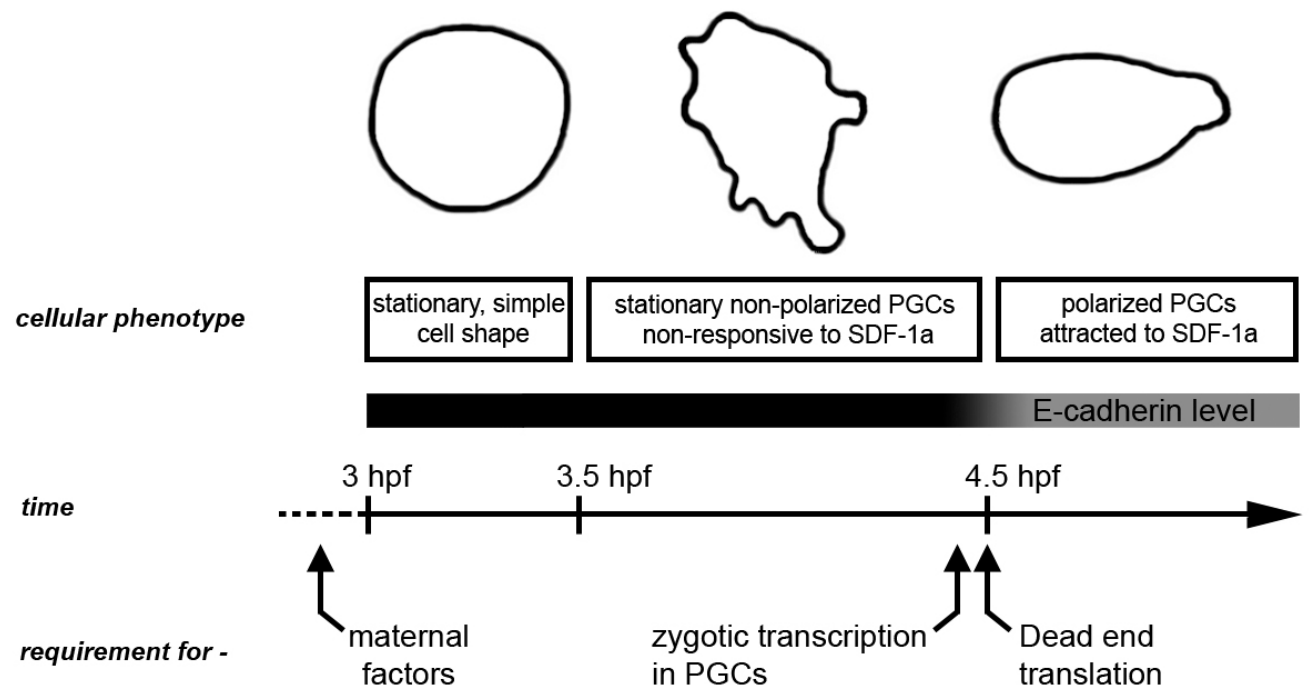

Fig. 4-1. Differentiation stages during early PGC development leading to motility, polarization and guided migration. Following their specification, a process which is controlled by maternallyprovided germ plasm (Hashimoto et al., 2004; Knaut et al., 2000; Yoon et al., 1997), the PGCs appear morphologically similar to somatic cells, yet they show expression of characteristic markers and can be specifically labelled with GFP. During the next stage, the PGCs assume a complex non-polarized morphology, express high levels of E-cadherin on their membrane and do not respond to guidance cues provided by the chemokine SDF-1a. Further differentiation depends on de novo transcription in the zygote since inhibition of transcription by $\alpha$-amanitin leads to a complete developmental arrest of PGCs at the second phase. The transition to the third stage relies on the function of the Dead end protein. This stage is characterized by moderate down regulation of E-cadherin and the competence of PGCs to polarize and migrate in response to directional cues.

\subsection{Molecular Mechanisms controlling PGC directional migration}

As mentioned above SDF-1a/CXCR4b signalling is essential for directional migration of germ cells after they become motile. The only molecules that have been shown to act downstream of CXCR4 in zebrafish PGC migration are Gi proteins (Dumstrei et al., 2004). This conclusion is based on the finding that inhibition of Gi signalling by expression of pertussis toxin (PTX) in the germ cells result in a phenotype similar to that of the loss of CXCR4b (Doitsidou et al., 2002; Dumstrei et al., 2004). With the exception of Gi-proteins, no other factors essential for PGC polarization and chemotaxis have been identified.

Previous studies highlighted the relevance of calcium signalling in migration and chemotaxis of different cell types (Pujol et al., 2005; Roland et al., 2003). For instance, buffering of intracellular $\mathrm{Ca}^{2+}$ transients in migrating neutrophils led to 
reduced motility (Eddy et al., 2000; Tian et al., 2003). SDF-1 signalling in lymphocytes triggered transient $\mathrm{Ca}^{2+}$ elevations upon CXCR4 activation. Such $\mathrm{Ca}^{2+}$ elevations are essential for lymphocyte motility shown by PTX treatment that blocked SDF-1 induced $\mathrm{Ca}^{2+}$ influx and abrogated cell migration (Vila-Coro et al., 1999).

In this work we could show that directional migrating PGCs in zebrafish exhibit increased $\mathrm{Ca}^{2+}$ levels at their leading edge. In PGCs lacking SDF-1a signalling $\mathrm{Ca}^{2+}$ levels were lower in the leading edge relative to those in wild-type and these cells exhibit a severe migration phenotype as was previously shown (Doitsidou et al., 2002). Consistent with the notion that calcium signalling plays a role in SDF-1a mediated migration, buffering calcium in the migrating PGCs resulted in migration defects. Both, CXCR4b knock-down (results in reduced $\mathrm{Ca}^{2+}$ elevations) and calcium buffered PGCs reside prolonged in 'tumbling' phases. Consequently, our results support the idea that calcium is important for the generation of front protrusions and maintaining run phases. Whereas the precise role of calcium in cell guidance is unknown, this ion has been implicated in guidance of growth cones as well where local alteration in $\mathrm{Ca}^{2+}$ levels triggered attraction or repulsion of the axon. Factors such as the amplitude and duration of specific calcium elevations influenced growth cone migration speed, the formation, stabilization or retraction of axonal and dendritic filopodia (reviewed in Gomez and Zheng, 2006). Moreover, buffering of intracellular $\mathrm{Ca}^{2+}$ elevations in migrating Dictyostelium resulted in fewer pseudopod formation and reduced locomotion (Eddy et al., 2000; Tian et al., 2003).

The likely calcium source used by PGCs is the extracellular environment and it is possible that molecules that act on ion channels on the plasma membrane control calcium influx. Constitutively activated STIM1 was localized to the plasma membrane primarily at the rear and the sides of migrating PGCs where increased protrusive activity was observed. According the function of STIM1, this molecule activates CRAC-channels on the plasma membrane, which facilitate the calcium influx from the extracellular environment (Liou et al., 2005; Manji et al., 2000; Roos et al., 2005; Williams et al., 2001; Zhang et al., 2005) hence local $\mathrm{Ca}^{2+}$ elevations through constitutively activated STIM1 promotes the formation of protrusions in PGCs. These results suggest that proteins (e.g. STIM-family), which activate $\mathrm{Ca}^{2+}$ channels on the plasma membrane (e.g. SOC, CRAC) are likely to be involved in controlling the formation of front protrusions in migrating germ cells. An attractive 
research direction is the investigation of possible interaction between molecules from the STIM-family and elements of the CXCR4 pathway.

Another interesting question is how calcium levels influence the cytoskeleton, cell morphology and behaviour. A well-known calcium effector protein is MLCK, which had indeed been showed to be critical for the regulation of motility in other cell types. We could observe MLCK localization in the front of directionally migrating PGCs and could show that a downstream target of MLCK, namely MLC was activated at the leading edge. All together, these results strongly suggest that MLCK controls actomyosin contraction in germ cell migration. Consistently, manipulations affecting myosin activity by using constitutively activated and dominant negative forms of MLCK as well as DAPK resulted in aberrant PGC migration with a strong effect on the protrusive behaviour and the establishment of cell polarity. Recently, we observed that actin and myosin (actomyosin cortex) in addition with MLCK co-localize at locations on the plasma membrane where newly formed protrusions appear (unpublished data from our lab).

Including recent unpublished data, a possible model could be that elevated calcium levels at the leading edge of migrating PGCs results in MLCK dependent MLC activation, which leads to enhanced actomyosin (cortex) based contraction at this location. This contraction could result in weakened cortex at this particular region allowing the formation of polarized protrusions by cytosolic flux (summarized in Fig. 4-2). Indeed, bright field microscopy of migrating PGCs revealed that protrusion extension coincides with cytosolic flux into the newly formed protrusion (unpublished data from our lab). Consistently, recent work performed in a filamin-depleted melanoma cell line, extensive and continuous 'blebbing' could be observed by protrusions driven by hydrostatic pressure instead of actin polymerization based mechanisms (Charras et al., 2005).

Numerous studies have shown that in addition to MLCK, the calcium independent Rho GTPase dependent kinase (ROCK) can control myosin II activity by either direct phosphorylation of MLC or the inhibition of MLCP (Katoh et al., 2001; Kawano et al., 1999). In non-muscle cells, MLCK has been proposed to regulate stress-fibre formation and the cortical actin network at the cell periphery, in contrast ROCK appears to act primarily within the cell body (Kamm and Stull, 2001; Riento et al., 2003; Somlyo and Somlyo, 2003; Totsukawa et al., 2000). These distinct locations of MLCK and ROCK activity might also be important during PGC migration by 
allowing the calcium dependent MLCK to establish the protrusions at the leading edge while ROCK supports the myosin II dependent retraction of the rear.

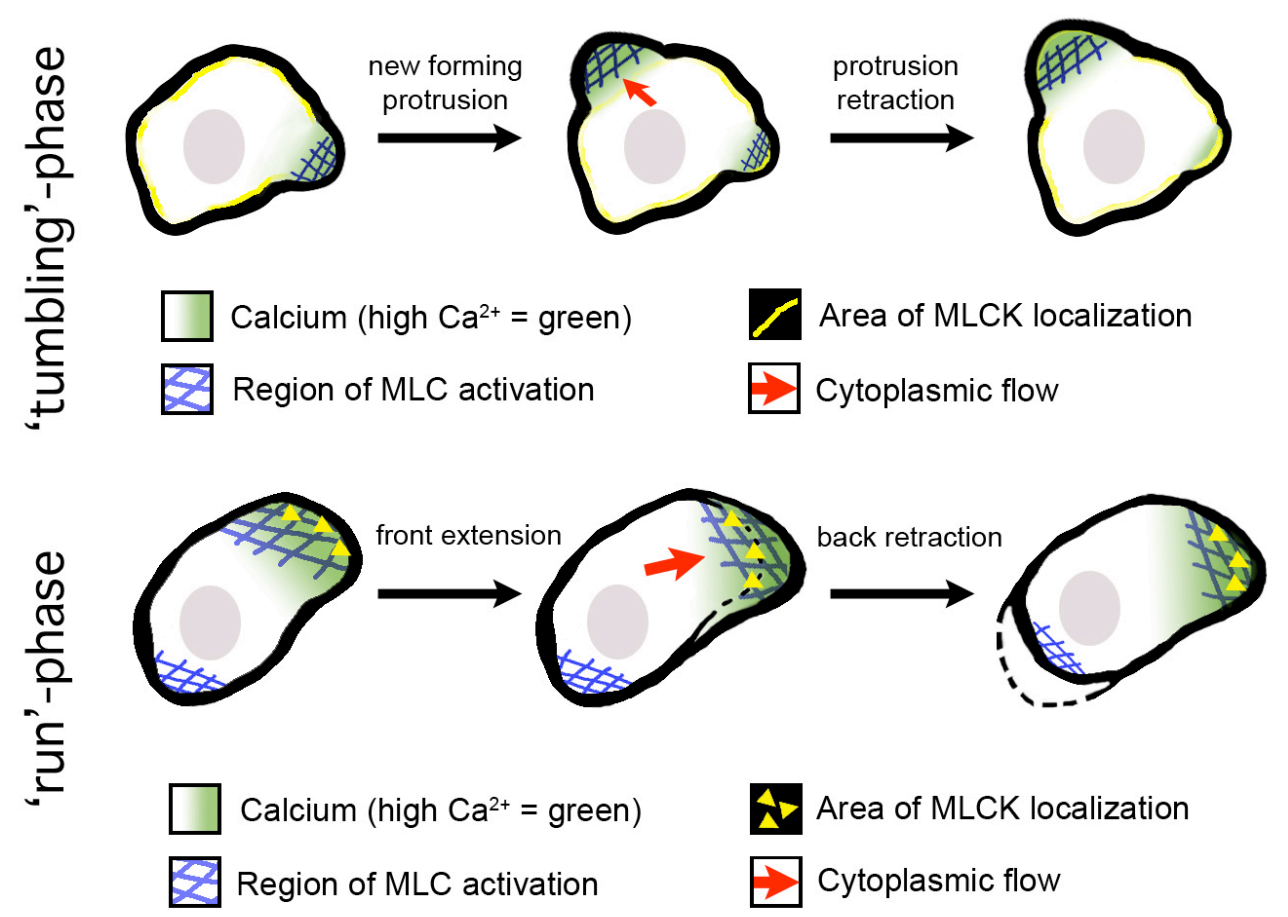

Fig. 4-2. Myosin contraction needed for the formation of protrusions in migrating PGCs.

During the non-polarized phase of PGC 'tumbling', MLCK is localized at the plasma membrane and allows spatially controlled formation of protrusions through the activation of MLC. Upon the onset of protrusion retraction, MLCK appears again at the plasma membrane at the tip of the protrusion. Throughout the 'run' phase of directionally migrating PGCs, intracellular calcium level is highest at the leading edge and mediates the activation of MLCK, which subsequently triggers myosin II contraction upon MLC phosphorylation. Activation of MLC at the back of migrating PGCs might be controlled by another kinase that facilitates rear retraction. The dashed lines reflect the cell margins of a migratory PGC before front extension and back retraction takes place.

Consistent with our findings, previously published data highlighted the importance of regulated MLCK activity for various migratory cell types (Wessels et al., 1988). For example, the inhibition of the MAP kinase pathway impaired MLC phosphorylation by MLCK and inhibited cell migration (Klemke et al., 1997). Conversely, urokinasetype plasminogen activator ( $\mathrm{UPA}$ ) activated MAP kinases that promoted MLCK activity and MLC phosphorylation, which accelerated cell migration of COS-7, human breast cancer and fibrosarcoma cells (Klemke et al., 1997; Nguyen et al., 1999). It has been assumed that MLCK might be involved in the formation of 
membrane protrusions at the leading edge of polarized cells (reviewed in Somlyo and Somlyo, 2003; Totsukawa et al., 2004; Webb et al., 2004).

It would be of general interest to determine if similar to zebrafish PGCs, proper migration of other cell types is equally dependent on polarized calcium levels and discrete localized actomyosin contraction of the cortex. The determination of the molecular basis for guided cell migration would help understanding different processes in normal development of an organism as well as pathological conditions caused by aberrant cell migration. This understanding would facilitate the development of therapies for diseases such as cancer, and chronic inflammation. The optical clarity of the zebrafish embryos and the fact that the PGCs utilize in their migration signals similar to those used by metastastatic cells makes this model especially suitable for in vivo studies of cell migration relevant for disease. 


\section{Summary and Conclusion}

In this study we have identified distinct steps in early PGC development following the specification of this lineage. These steps are essential for the transformation of the cells into motile cells that are able to respond to guidance cues. These "maturation" steps were found to depend on de novo RNA synthesis and on the function of a specific protein - Dead end. The transition into motile cell behaviour was correlated with alterations in E-cadherin levels in the PGCs suggesting that modulations of adhesion between germ cells and their neighbours play a role in PGC maturation. Similar alterations in cadherin protein expression level and distribution have been suggested to be important in the regulation of epithelial-mysenchemal transition in many different cell-types.

Following the acquisition of motility, PGCs were able to respond to the guidance cue SDF-1a. During these stages of guided migration, we could demonstrate that intracellular free calcium level was higher at the leading edge of directionally migrating PGC. In cells lacking CXCR4b signalling, this bias in calcium distribution was much less pronounced. The relevance of calcium for PGC migration was demonstrated by manipulating its distribution. Such manipulations resulted in abnormal protrusive activity as well as cell polarization defects. We suggest that calcium regulates the degree of actomyosin contractility at the leading edge by controlling the activity of MLC kinases (MLCK, DAPK or any calcium dependent kinase that activates MLC). Consistently, appropriate MLCK or DAPK activity was crucial for accurate PGC motility especially for the establishment of cell polarity.

In conclusion, the transition from a non-motile to a motile cell is a critical process during normal development and pathological processes. Detailed analysis of protein and RNA compositions comparing germ cells from stages before and after the time of their transition should identify factors involved in the transition into motile cell behaviour. Although we identified some important factors involved in PGC migration, the more complete list of players involved in this sophisticated molecular machinery governing germ cell chemotaxis has still to be discovered. Specifically, studies focusing on determining the role of calcium and its effectors in guided PGC migration should provide important clues relevant for similar processes involved in normal and aberrant migration of different cell types. 


\section{$6 \quad$ Material and Methods}

\section{$\underline{6.1 \quad \text { Bacteria strains }}$}

\begin{tabular}{|l|l|l|}
\hline Bacteria & Company & Description \\
\hline Top 10F' & Invitrogen & E. coli competent cells, for plasmid DNA electroporation \\
\hline DH5 $\alpha$ & Invitrogen & E. coli competent cells, for plasmid DNA electroporation \\
\hline
\end{tabular}

\subsection{Chemicals}

\begin{tabular}{|l|l|l|l|}
\hline Product-Name & Company & Description & Working concentration \\
\hline$\alpha$-amanitin & Sigma & Transcription inhibitor & $200 \mu \mathrm{g} / \mathrm{mL}$ \\
\hline $\begin{array}{l}\text { Oregon Green BAPTA } \\
488 \text { (Dextran 10,000) }\end{array}$ & $\begin{array}{l}\text { Molecular } \\
\text { Probes }\end{array}$ & Calcium indicator & $0.5 \mathrm{mM}$ injection solution \\
\hline $\begin{array}{l}\text { Alexa Fluor 568 } \\
\text { (Dextran 10,000) }\end{array}$ & $\begin{array}{l}\text { Molecular } \\
\text { Probes }\end{array}$ & Dye to label cells & $0.15 \mathrm{ng} / \mathrm{embryo}$ \\
\hline $\begin{array}{l}\text { Oregon Green 488 } \\
\text { (Dextran 70,000) }\end{array}$ & $\begin{array}{l}\text { Molecular } \\
\text { Probes }\end{array}$ & Dye to label cells & $6,3 \mathrm{ng} / \mathrm{embryo}$ \\
\hline
\end{tabular}

\subsection{Plasmids/Constructs}

\begin{tabular}{|l|l|l|}
\hline Name & Description & $\begin{array}{l}\text { RNA/DNA } \\
\text { concentration }\end{array}$ \\
\hline RZPD PAC clone \\
BUSMP706O19135Q2 & $\begin{array}{l}\text { Zebrafish genomic PAC-library 706, } 4.9 \\
\text { kbp region upstream of the first exon of } \\
k \text { op used to clone the promoter region }\end{array}$ & \\
\hline pSP64-gfp-3'UTRnos1 & $\begin{array}{l}\text { Labels specifically the whole PGC with } \\
\text { GFP }\end{array}$ & $210-240 \mathrm{pg}$ \\
\hline pSP64-gfp-globin-3'UTR & Labels all cells with GFP & $6-15 \mathrm{pg}$ \\
\hline pSP64-EGFP-F-nos1-3'UTR & $\begin{array}{l}\text { Labels specifically the PGC membrane } \\
\text { with EGFP }\end{array}$ & $150-300 \mathrm{pg}$ \\
\hline
\end{tabular}




\begin{tabular}{|c|c|c|}
\hline pSP64-kop-globin-3'UTR & $\begin{array}{l}\text { Askopos expressed in all cells of the } \\
\text { embryo }\end{array}$ & $150-900 \mathrm{pg}$ \\
\hline pSP64-kop-nos1-3'UTR & $\begin{array}{l}\text { Askopos specifically expressed in the } \\
\text { PGCs }\end{array}$ & $150-900 \mathrm{pg}$ \\
\hline pSP64-kop-gfp-nos1-3'UTR & $\begin{array}{l}\text { Shows the localization of askopos } \\
\text { protein in PGCs }\end{array}$ & $300 \mathrm{pg}$ \\
\hline pSP64-DNkop-globin-3'UTR & G280S mutant & $150-900 \mathrm{pg}$ \\
\hline DsRedex1-nos1-3'UTR & $\begin{array}{l}\text { Labels specifically the whole PGC with } \\
\text { DsRedex } 1\end{array}$ & $300 \mathrm{pg}$ \\
\hline kop-EGFP-F-nos1-3'UTR & promoter construct & $15 \mathrm{pg}$ \\
\hline I-SceI-pBSII-SK+ vector & $\begin{array}{l}\text { Vector to create transgenic fish by } \\
\text { means of the SceI Meganuclease }\end{array}$ & \\
\hline pSP64-E-cadh1-nos1-3'UTR & $\begin{array}{l}\text { Force expresses E-cadherin only in the } \\
\text { PGCs }\end{array}$ & $90 \mathrm{pg}$ \\
\hline sdf-1a-globin-3'UTR & $\begin{array}{l}\text { This RNA is expressed in all cells of the } \\
\text { embryo, used for sdf-1a over expression }\end{array}$ & $240 \mathrm{pg}$ \\
\hline DsRedex1-globin-3'UTR & Labels all cells with DsRedex 1 & $6-15 \mathrm{pg}$ \\
\hline egfp-f-globin-3'UTR & Labels all cells with membrane EGFP & $6-15 \mathrm{pg}$ \\
\hline pSP64-dtt-nos1-3'UTR & $\begin{array}{l}\text { diphtheria toxin A-chain expressed by } \\
\text { PGCs only, leads to cell death }\end{array}$ & $0,15 \mathrm{pg}$ \\
\hline pSP64-pvlb-nos1-3'UTR & $\begin{array}{l}\text { Force expresses parvalbumin } \\
\text { specifically in the PGCs }\end{array}$ & $600-1350 \mathrm{pg}$ \\
\hline pSP64-calbD9K-nos1-3'UTR & $\begin{array}{l}\text { Force expresses calbindinD9k } \\
\text { specifically in the PGCs }\end{array}$ & $600-1350 \mathrm{pg}$ \\
\hline pSP64-calbD28K-nos1-3'UTR & $\begin{array}{l}\text { Force expresses calbindinD28k } \\
\text { specifically in the PGCs }\end{array}$ & $600-1350 \mathrm{pg}$ \\
\hline pSP64-pvlb-f-nos 1-3'UTR & $\begin{array}{l}\text { Force expresses parvalbumin } \\
\text { specifically at the PGC membrane }\end{array}$ & $600-1350 \mathrm{pg}$ \\
\hline pSP64-calbD9K-f-nos1-3'UTR & $\begin{array}{l}\text { Force expresses calbindinD9k } \\
\text { specifically at the PGC membrane }\end{array}$ & $600-1350 \mathrm{pg}$ \\
\hline pSP64-calbD28K-f-nos1-3'UTR & $\begin{array}{l}\text { Force expresses calbindinD } 28 \mathrm{k} \\
\text { specifically at the PGC membrane }\end{array}$ & $600-1350 \mathrm{pg}$ \\
\hline
\end{tabular}




\begin{tabular}{|c|c|c|}
\hline pSP64-mutpvlb-f-nos1-3'UTR & $\begin{array}{l}\text { Force expresses non functional } \\
\text { parvalbumin (EF-hand mutated) } \\
\text { specifically at the PGC membrane }\end{array}$ & $600-1350 \mathrm{pg}$ \\
\hline MLCK-FIP-nos1-3'UTR & $\begin{array}{l}\text { Shows the localization of myosin light } \\
\text { chain kinase protein (MLCK) in PGCs } \\
\text { (FRET) }\end{array}$ & $450 \mathrm{pg}$ \\
\hline MLCK-WT-nos1-3'UTR & $\begin{array}{l}\text { Force expresses MLCK specifically in } \\
\text { the PGCs }\end{array}$ & $300-900 \mathrm{pg}$ \\
\hline CA-MLCK-nos1-3'UTR & $\begin{array}{l}\text { Force expresses constitutive activated } \\
\text { MLCK specifically in the PGCs }\end{array}$ & $300-900 \mathrm{pg}$ \\
\hline DN-MLCK-nos1-3'UTR & $\begin{array}{l}\text { Force expresses dominant negative } \\
\text { MLCK specifically in the PGCs }\end{array}$ & $300-1200 \mathrm{pg}$ \\
\hline STIM1-DsRedex1-nos1-3'UTR & $\begin{array}{l}\text { Shows the localization of STIM1 } \\
\text { protein in PGCs }\end{array}$ & $300 \mathrm{pg}$ \\
\hline mutSTIM1-DsRedex1-nos1-3'UTR & $\begin{array}{l}\text { Force expresses mutated form of } \\
\text { STIM1 }\left(\mathrm{STIM} 1^{\mathrm{M}} \text { ) specifically in the }\right. \\
\text { PGCs (showed localization and } \\
\text { phenotype) }\end{array}$ & $300 \mathrm{pg}$ \\
\hline DN-DAPK-1a-nos1-3'UTR & $\begin{array}{l}\text { Force expresses dominant negative } \\
\text { death associated protein kinase (DAPK) } \\
\text { specifically in the PGCs }\end{array}$ & $300-900 \mathrm{pg}$ \\
\hline CA-DAPK-1a-nos1-3'UTR & $\begin{array}{l}\text { Force expresses constitutively activated } \\
\text { DAPK specifically in the PGCs }\end{array}$ & $300-900 \mathrm{pg}$ \\
\hline CRCit-nos1-3'UTR & ECFP-MLC-Citrine (MLC-FRET) & $450-900 \mathrm{pg}$ \\
\hline mCRCitAA-nos 1-3'UTR & $\begin{array}{l}\text { ECFP-mut-T18A/S19A-MLC-Citrine } \\
\left(\text { MLC }^{\mathrm{M}} \text {-FRET) }\right.\end{array}$ & $450-900 \mathrm{pg}$ \\
\hline DsRedex1-f-nos1-3'UTR & $\begin{array}{l}\text { Labels specifically the PGC membrane } \\
\text { with DsRedex } 1\end{array}$ & $210-300 \mathrm{pg}$ \\
\hline vasa-DsRedex1-nos1-3'UTR & $\begin{array}{l}\text { Labels the germ granules in PGCs with } \\
\text { DsRedex } 1\end{array}$ & $180 \mathrm{pg}$ \\
\hline
\end{tabular}




\subsection{Antisense probes for insitu hybridization}

\begin{tabular}{|c|c|}
\hline Name & Description of Expression pattern \\
\hline Kop-Dig & $\begin{array}{l}\text { Askopos RNA is localized first to the germ plasm and later restricted to } \\
\text { germ cells. }\end{array}$ \\
\hline Nanos1-Dig & $\begin{array}{l}\text { Nanos } 1 \text { RNA is localized first to the germ plasm and later restricted to } \\
\text { germ cells. }\end{array}$ \\
\hline Nanos1-Fluo & $\begin{array}{l}\text { Nanos } 1 \text { RNA is localized first to the germ plasm and later restricted to } \\
\text { germ cells. }\end{array}$ \\
\hline Vasa-Dig & $\begin{array}{l}\text { Vasa RNA is localized first to the germ plasm and later restricted to } \\
\text { germ cells with some additional tissues in the embryo. }\end{array}$ \\
\hline E-cadherin-Dig & $\begin{array}{l}\text { E-cadherin RNA is ubiquitously expressed in the embryo which includes } \\
\text { the PGCs. }\end{array}$ \\
\hline GFP-Dig & $\begin{array}{l}\text { GFP RNA is only detected upon injection of RNA, which includes GFP } \\
\text { sequence into the zebrafish embryo. }\end{array}$ \\
\hline EGFP-Dig & $\begin{array}{l}\text { EGFP RNA is only detected upon injection of RNA, which includes GFP } \\
\text { sequence into the zebrafish embryo or by using the kop-EGFP- } \\
\text { 3'UTRnos1 transgenic fish. }\end{array}$ \\
\hline SDF-1a-Dig & $\begin{array}{l}\text { SDF RNA is expressed from } 1 \mathrm{k} \text {-stage on; its expression pattern reflects } \\
\text { the route of PGC migration during the } 1 \text { day of development. }\end{array}$ \\
\hline MLCK-Dig & $\begin{array}{l}\text { MLCK RNA is ubiquitously expressed in the embryo which includes the } \\
\text { PGCs. }\end{array}$ \\
\hline DAPK-Dig & $\begin{array}{l}\text { DAPK RNA is ubiquitously expressed in the embryo which includes the } \\
\text { PGCs. }\end{array}$ \\
\hline STIM1-Dig & $\begin{array}{l}\text { STIM1 RNA is ubiquitously expressed in the embryo which includes the } \\
\text { PGCs. }\end{array}$ \\
\hline
\end{tabular}




\subsection{Morpholino antisense oligo nucleotides}

\begin{tabular}{|l|l|l|}
\hline Name & Conc. & Sequence \\
\hline Kop-MO & $0.6-5.4 \mathrm{pmol}$ & 5'-GAATGGATGTATCTGTGAATGACAT-3' \\
\hline$d n d-\mathrm{MO}$ & $1200 \mathrm{pg}$ & 5'-GCTGGGCATCCATGTCTCCGACCAT-3' \\
\hline CXCR4b & $200 \mu \mathrm{M}$ & 5'-AAATGATGCTATCGTAAAATTCCAT-3' \\
\hline Sdf-1a & $0.4 \mathrm{pmol}$ & 5'-TTGAGATCCATGTTTGCAGTGTGAA-3' \\
\hline Sdf-1b & $0.4 \mathrm{pmol}$ & 5'-GCGCTACTACTTTGCTATCCATGCC-3' \\
\hline
\end{tabular}

\section{$\underline{6.6 \quad \text { Antibodies }}$}

Primary antibodies:

\begin{tabular}{|l|l|l|l|l|}
\hline Name & Epitope & Host & Conc. & Company \\
\hline anti-GFP & GFP (FL), polyclonal & rabbit & $1: 200$ & $\begin{array}{l}\text { Santa Cruz } \\
\text { Biotechnology }\end{array}$ \\
\hline anti-E-cdh & human E-cadherin & mouse & $1: 100$ & $\begin{array}{l}\text { Transduction } \\
\text { Laboratories }\end{array}$ \\
\hline
\end{tabular}

$\underline{\text { Secondary antibodies: }}$

\begin{tabular}{|l|l|l|l|l|}
\hline Name & Host & Fluophore & Conc. & Company \\
\hline $\begin{array}{l}\text { Alexa Fluor 488-anti- } \\
\text { rabbit }\end{array}$ & goat & $\begin{array}{l}\text { Alexa Fluor 488- } \\
\text { conjugated }\end{array}$ & $1: 200$ & Molecular Probes \\
\hline $\begin{array}{l}\text { Alexa Fluor 546-anti- } \\
\text { mouse }\end{array}$ & goat & $\begin{array}{l}\text { Alexa Fluor 546- } \\
\text { conjugated }\end{array}$ & $1: 200$ & Molecular Probes \\
\hline
\end{tabular}




\subsection{Kits}

\begin{tabular}{|c|c|c|}
\hline Product-Name & Company & Description \\
\hline 5'/3' RACE system & Invitrogen & Rapid amplification of cDNA ends \\
\hline $\begin{array}{l}\text { QIAfilter Plasmid Kit, } \\
\text { Plasmid or Cosmid DNA } \\
\text { Purification Using } \\
\text { HiSpeed Plasmid Midi } \\
\text { and Maxi Kits }\end{array}$ & QIAGEN & $\begin{array}{l}\text { Plasmid DNA isolation of Mini, Midi and Maxi } \\
\text { preparations }\end{array}$ \\
\hline $\begin{array}{l}\text { QIAquick Gel Extraction } \\
\text { Kit }\end{array}$ & QIAGEN & $\begin{array}{l}\text { DNA fragment }(70 \mathrm{bp}-10 \mathrm{~kb}) \text { extraction from } \\
\text { TAE/TBE agarose gels }\end{array}$ \\
\hline $\begin{array}{l}\text { QIAquick PCR } \\
\text { Purification Kit }\end{array}$ & QIAGEN & $\begin{array}{l}\text { Direct purification of double- or single-stranded PCR } \\
\text { products }(100 \mathrm{bp}-10 \mathrm{~kb})\end{array}$ \\
\hline EndoFree Plasmid Kit & QIAGEN & Endotoxin-free ultrapure Plasmid DNA isolation \\
\hline Red-VAD-FMK & BIOCAT & Stains dying cells for activated caspases \\
\hline Phusion Kit & Finnzymes & High fidelity DNA amplification/PCR \\
\hline Advantage HF 2 PCR Kit & Clontech & High fidelity DNA amplification/PCR \\
\hline OmniScript RT Kit & QIAGEN & Standard reverse transcription \\
\hline TOPO TA Cloning Kit & Invitrogen & $\begin{array}{l}\text { Enables fast, efficient cloning of Taq-amplified PCR } \\
\text { products }\end{array}$ \\
\hline Message Machine Kit & Ambion & Capped sense RNA \\
\hline
\end{tabular}




\subsection{Tools/Hardware}

\begin{tabular}{|c|c|}
\hline Product Description & Company \\
\hline MZ FLIII stereomicroscope & Leica \\
\hline Confocal microscope TCS SL & Leica \\
\hline Axioplan 2 microscope & Zeiss \\
\hline RT slider spot camera & Diagnostic Instruments \\
\hline RT SE spot camera & Diagnostic Instruments \\
\hline PN-30 Needle puller & Science Product \\
\hline Microinjector PV830 Pneumatic PicoPump & World precision Instruments \\
\hline Needle polisher Micro Forge MF-830 & $\begin{array}{l}\text { Narishige Scientific Instrument Lab., } \\
\text { Japan }\end{array}$ \\
\hline PCR machine Mastercycler personal & Eppendorf \\
\hline PCR machine MyCycler & Bio Rad \\
\hline PCR machine Cyclone 96 & PEQLA \\
\hline Insitu machine BioLane HTI & Hölle \& Hüttner AG \\
\hline water bath WB-7 & Memert GmbH \\
\hline pH-meter MP220 & Mettler Toledo \\
\hline Electroporation MicroPulser & Bio Rad \\
\hline $\begin{array}{l}\text { BioPhotometer Eppendorf for DNA, RNA and protein } \\
\text { concentrations }\end{array}$ & Eppendorf \\
\hline Gel chambers ComPhor L Mini, Midi & Bioplastics BV \\
\hline Power supply EC105 & E-C Apparatus Corporation \\
\hline Centrifuge Biofuge primo $\mathrm{R}$, rotor $\# 7590$, max. $8500 \mathrm{rpm}$ & Heraeus \\
\hline $\begin{array}{l}\text { Centrifuge Eppendorf 5415D, rotor F45-24-11, max. } 13200 \\
\text { rpm }\end{array}$ & Eppendorf \\
\hline Heating block Type BBA2 & Grant-Boekel \\
\hline Cooling block Thermomixer comfort & Eppendorf \\
\hline Fish incubator BK600 & Heraeus, Kendro \\
\hline Bacteria incubator Type 3031 & GFL \\
\hline
\end{tabular}




\subsection{Software}

\begin{tabular}{|c|c|}
\hline Software-Name & Product Description \\
\hline Vector NTI (Invitrogen) & $\begin{array}{l}\text { Application for DNA and protein sequence } \\
\text { analysis. }\end{array}$ \\
\hline ZFIN (The Zebrafish Information Network) & $\begin{array}{l}\text { ZFIN serves as the zebrafish model organism } \\
\text { database. }\end{array}$ \\
\hline $\begin{array}{l}\text { The Danio rerio Sequencing Project } \\
\text { (Sanger Institute) }\end{array}$ & $\begin{array}{l}\text { the genome sequencing project of the zebrafish } \\
\text { (Danio rerio) following two strategies: clone } \\
\text { mapping and sequencing from BAC and PAC } \\
\text { libraries and whole genome shotgun sequencing } \\
\text { with subsequent assembly }\end{array}$ \\
\hline $\begin{array}{l}\text { NCBI-BLAST (Basic Local Alignment Search } \\
\text { Tool) }\end{array}$ & $\begin{array}{l}\text { Finds regions of local similarity between } \\
\text { sequences. The program compares nucleotide or } \\
\text { protein sequences to sequence databases and } \\
\text { calculates the statistical significance of matches. }\end{array}$ \\
\hline $\begin{array}{l}\text { The ExPASy (Expert Protein Analysis System) } \\
\text { proteomics server }\end{array}$ & $\begin{array}{l}\text { Used for the analysis of protein sequences and } \\
\text { structures. }\end{array}$ \\
\hline Sequencher 4.5 (Gene Codes Corporation) & $\begin{array}{l}\text { Aligns sequences in respect of their similarity to } \\
\text { create contigs. }\end{array}$ \\
\hline Metamorph (Universal Imaging) & $\begin{array}{l}\text { Image acquisition/archival system, processing } \\
\text { capabilities (motion analysis, co-localization, } \\
\text { multi-dimensional acquisition and analysis, etc.) }\end{array}$ \\
\hline Leica confocal software & $\begin{array}{l}\text { Performs system control, 2D-3D imaging and } \\
\text { processing }\end{array}$ \\
\hline
\end{tabular}




\section{$\underline{6.10 \quad M o l e c u l a r ~ B i o l o g y}$ - general protocols}

\subsubsection{RNA extraction and cDNA synthesis}

\section{$\underline{\text { RNA extraction from zebrafish embryos: }}$}

About 50 embryos were grown to a certain stage of development, transferred into 200 $\mu \mathrm{L}$ Trizol reagent (Gibco BRL-Life Technologies) and homogenized with a glassteflon pistil. Following homogenization, $800 \mu \mathrm{L}$ Trizol reagent were added then the cell suspension was centrifuged $\left(12 \mathrm{~min}, 12000 \mathrm{rpm}, 4^{\circ} \mathrm{C}\right)$ to further process the liquid phase and to discard the pellet. Next, the liquid phase was incubated at RT for about $5 \mathrm{~min}$ to dissociate associated proteins on the RNA. $200 \mu \mathrm{L}$ of chloroform was added, shacked and incubated for about $2 \mathrm{~min}$ at RT followed by spinning (15 min, $12000 \mathrm{rpm}, 4^{\circ} \mathrm{C}$ ). The upper (aqueous phase including the RNA) was transferred into a new Eppendorf-tube and $500 \mu \mathrm{L}$ iso-propyl alcohol was added before shacking and spinning (10 min, $\left.12000 \mathrm{rpm}, 4^{\circ} \mathrm{C}\right)$. The supernatant was discarded and the residual

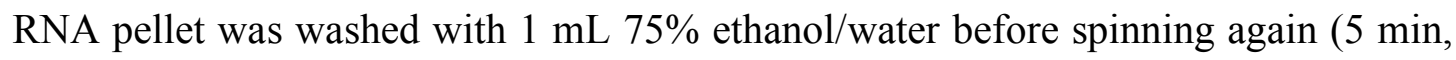
$\left.7000 \mathrm{rpm}, 4^{\circ} \mathrm{C}\right)$. The ethanol was removed, the pellet got air-dried and finally the RNA was dissolved in $20 \mu \mathrm{L}$ HEPES solution (10mM, pH 7.4).

\section{First-strand cDNA synthesis (reverse-transcription):}

1. Thaw template RNA on ice.

2. Thaw the primer solutions, 10x Buffer RT, dNTP Mix, and RNase-free water at room temperature

3. Prepare a fresh master mix on ice according to bellow's Table 1. Note: The protocol is optimized for use with $50 \mathrm{ng}$ to $2 \mu \mathrm{g}$ RNA.

4. Add template RNA to the individual tubes containing the master mix.

5. Incubate for $60 \mathrm{~min}$ at $37^{\circ} \mathrm{C}$.

6. Store the cDNA at $-20^{\circ} \mathrm{C}$ (can be used directly for amplifications by PCR) 
Master mix (standard example):

\begin{tabular}{|l|l|l|}
\hline Component & Vol/Reaction & Final Concentration \\
\hline 10x Buffer RT & $2 \mu \mathrm{L}$ & $1 \mathrm{x}$ \\
\hline dNTP Mix $(5 \mathrm{mM}$ each dNTP) & $2 \mu \mathrm{L}$ & $0.5 \mathrm{mM}$ each dNTP \\
\hline Oligo-dT primer $(10 \mathrm{mM})$ & $2 \mu \mathrm{L}$ & $1 \mathrm{mM}$ \\
\hline RNase inhibitor $(10$ units/ $\mu \mathrm{L})$ & $1 \mu \mathrm{L}$ & 10 units (per $20 \mu \mathrm{L}$ reaction) \\
\hline $\begin{array}{l}\text { Omniscript Reverse } \\
\text { Transcriptase }\end{array}$ & $1 \mu \mathrm{L}$ & 4 units (per $20 \mu \mathrm{L}$ reaction) \\
\hline RNase-free water & Variable & \\
\hline Template RNA, & Variable & Up to $2 \mu \mathrm{g}(\mathrm{per} 20 \mu \mathrm{L}$ reaction) \\
\hline Total volume & $\mathbf{2 0} \mu \mathrm{L}$ & \\
\hline
\end{tabular}

Table 1. Reverse-Transcription Reaction Components

\section{$\underline{6.10 .2}$ Polymerase chain reaction (PCR)}

Any primer, which was used for PCR amplification and sequencing was produced by the following manufacturers; IBA (Göttingen, Germany), MWG (Ebersberg, Germany) and VBC-Genomics (Vienna, Austria)

Three different PCR conditions, respectively DNA polymerases were used; TaqPolymerase (Invitrogen), HF-Polymerase (Clontech), Phusion-Polymerase (Finnzymes). The Taq- and HF-polymerase provide the PCR product with adenine overhangs whereas the Phusion-Polymerase give rise to blunt-ended DNA strands. Standard PCR mixture and a standard PCR program are shown in the following two Tables (A, B correspond to different DNA templates and 1, 2 and 3 depict different DNA polymerases). 


\begin{tabular}{|c|c|c|}
\hline Component & Conc. & Volume \\
\hline $\begin{array}{l}\text { Template: } \\
\text { (A) Plasmid-DNA } \\
\text { (B) } \text { cDNA }\end{array}$ & $\begin{array}{l}50 \mathrm{ng} / \\
\text { Reaction }\end{array}$ & $1 \mu \mathrm{L}$ \\
\hline Primer 1 & $10 \mu \mathrm{M}$ & $1 \mu \mathrm{L}$ \\
\hline Primer 2 & $10 \mu \mathrm{M}$ & $1 \mu \mathrm{L}$ \\
\hline dNTPs & $2.5 \mathrm{mM}$ & $1.5 \mu \mathrm{L}$ \\
\hline PCR buffer & $10 x$ & $2 \mu \mathrm{L}$ \\
\hline $\begin{array}{l}{ }^{(1)} \mathrm{Taq} \\
{ }^{(2)} \mathrm{HF} \\
{ }^{(3)} \text { Phusion }\end{array}$ & $\begin{array}{l}5 \mathrm{U} / \mu \mathrm{L} \\
5 \mathrm{U} / \mu \mathrm{L} \\
2 \mathrm{U} / \mu \mathrm{L}\end{array}$ & $0.5-1 \mu \mathrm{L}$ \\
\hline $\mathrm{dH} 2 \mathrm{O}$ & & $12.5-13 \mu \mathrm{L}$ \\
\hline Total & & $20 \mu \mathrm{L}$ \\
\hline
\end{tabular}

\begin{tabular}{|l|l|l|}
\hline \multicolumn{2}{|l|}{ Program: } & \multicolumn{2}{l|}{ Cycles } \\
\hline Temp & Time & \\
\hline${ }^{(1)} 94-{ }^{(2,3)} 98^{\circ} \mathrm{C}$ & ${ }^{(\mathrm{A})} 2-{ }^{(\mathrm{B})} 10 \mathrm{~min}$ & $1 \mathrm{x}$ \\
\hline $94-98^{\circ} \mathrm{C}$ & $20-30 \mathrm{~s}$ & $20-$ \\
\hline $50-60^{\circ} \mathrm{C}$ & $20-30 \mathrm{~s}$ & $30 \mathrm{x}$ \\
\hline${ }^{(2)} 68-{ }^{(1,3)} 72^{\circ} \mathrm{C}$ & $800-2000$ & \\
\hline${ }^{(2)} 68-{ }^{(1,3)} 72^{\circ} \mathrm{C}$ & $4-7 \mathrm{~min}$ & $1 \mathrm{x}$ \\
\hline $4^{\circ} \mathrm{C}$ & hold & \\
\hline
\end{tabular}

Table 3. Standard PCR program

Table 2. PCR reaction mix

\subsubsection{DNA separation on agarose gels}

\section{TAE Agarose Gel (standard example):}

2,5 g SeaKem LE-Agarose (Biozyme) was dissolved in $250 \mathrm{~mL}$ TAE agarose running buffer by heating in a microwave. The agarose solution was cooled down to about 40 - $50^{\circ} \mathrm{C}$ before $15 \mu \mathrm{L}$ of a $1 \%$ Ethidium-bromide solution (Merck) was added before the viscous mixture was poured into the sledge of a ComPhor Gel chamber. Combs of different sizes (vary in loading volume) are provided by the supplier. After the agarose gel polymerized, the chamber was filled with TAE running buffer until the gel was covered by a 3-5 mm. DNA got supplemented with $6 x$ blue loading dye (Fermentas) and loaded into the slots of the gel. To compare the sizes of the loaded DNA fragments, a 'DNA ladder' (Fermentas; $\lambda$ DNA-EcoRI/HindIII, $100 \mathrm{bp}, 1 \mathrm{~kb}$ ) was loaded into an empty slot next to the DNA samples. The power-supply was used between 50-120 milliamps to run the DNA through the agarose gel. 


\subsubsection{DNA extraction from agarose gels}

\section{Protocol:}

\begin{tabular}{|c|c|c|c|}
\hline Step & Description & Temp. & Time \\
\hline 1 & $\begin{array}{l}\text { Excise the DNA fragment from the agarose gel with a clean, sharp } \\
\text { scalpel. }\end{array}$ & RT & \\
\hline 2 & $\begin{array}{l}\text { Weigh the gel slice in an Eppendorf tube. Add } 3 \text { volumes of Buffer } \\
\text { QG to } 1 \text { volume of gel }(100 \mathrm{mg} \sim 100 \mu \mathrm{l}) \text {. }\end{array}$ & RT & \\
\hline 3 & $\begin{array}{l}\text { Dissolve the gel; mix by vortexing the tube every } 2-3 \text { min during } \\
\text { the incubation. }\end{array}$ & $50^{\circ} \mathrm{C}$ & $10 \mathrm{~min}$ \\
\hline 4 & $\begin{array}{l}\text { After the gel slice has dissolved completely, add } 1 \text { gel volume of } \\
\text { isopropanol to the sample and mix. ( } 100 \mathrm{mg} \mathrm{gel}=100 \mu \mathrm{l} \\
\text { isopropanol) }\end{array}$ & RT & \\
\hline 5 & $\begin{array}{l}\text { To bind the DNA, apply the sample to the QIAquick column, which } \\
\text { was inserted into a provided } 2 \mathrm{~mL} \text { collection tube, wait } 5 \mathrm{~min} \text { and } \\
\text { centrifuge ( } 13000 \mathrm{rpm}) .\end{array}$ & RT & $1 \mathrm{~min}$ \\
\hline 6 & $\begin{array}{l}\text { Discard the flow-through and place the QIAquick column back in } \\
\text { the same collection tube. }\end{array}$ & RT & \\
\hline 7 & $\begin{array}{l}\text { To wash, add } 750 \mu \mathrm{L} \text { of Buffer PE to the QIAquick column, wait } 5 \\
\text { min and centrifuge (13000 rpm). }\end{array}$ & RT & $1 \mathrm{~min}$ \\
\hline 8 & $\begin{array}{l}\text { Discard the flow-through and place the QIAquick column back in } \\
\text { the same collection tube and centrifuge again to remove residual PE } \\
\text { traces }(13000 \mathrm{rpm}) .\end{array}$ & $\mathrm{RT}$ & $2 \min$ \\
\hline 9 & Place the QIAquick column into a clean $1.5 \mathrm{~mL}$ Eppendorf tube. & RT & \\
\hline 10 & $\begin{array}{l}\text { To elute DNA, add } 30-50 \mu \mathrm{L} \text { of Buffer EB }(10 \mathrm{mM} \text { Tris } \cdot \mathrm{Cl}, \mathrm{pH} \\
8.5) \text { to the center of the QIAquick membrane, wait for } 1-5 \mathrm{~min} \\
\text { and centrifuge the column }(13000 \mathrm{rpm}) \text {. }\end{array}$ & $\mathrm{RT}$ & $1.5 \mathrm{~min}$ \\
\hline
\end{tabular}




\subsubsection{Enzymatic DNA digestions and modifications for cloning purposes}

Restriction enzyme digest:

Enzymes were provided by NEB (New England Biolabs, Frankfurt, Germany) and Fermentas (St. Leon-Rot, Germany).

\section{$\underline{\text { Reaction (standard example): }}$}

\begin{tabular}{|l|l|l|}
\hline Component & Concentration & Volume \\
\hline Sample: & $2-5 \mu \mathrm{g} /$ Reaction & $1-5 \mu \mathrm{L}$ \\
(2) PCR product & & \\
\hline Reaction buffer & $10 \mathrm{x}$ & $10 \mu \mathrm{L}$ \\
\hline BSA (optional) & $100 \mathrm{x}$ & $1 \mu \mathrm{L}$ \\
\hline Enzyme & $5-20 \mathrm{U} / \mu \mathrm{L}$ & $1-2 \mu \mathrm{L}$ per enzyme \\
\hline dH2O & & $82 \mu \mathrm{L}$ \\
\hline Total & & $\mathbf{1 0 0} \mu \mathrm{L}$ \\
\hline
\end{tabular}

Table 4. Restriction Enzyme reaction mix

Duration: 1-3 hours depending on the amount of DNA and the enzyme especially about the enzyme activity. The reactions were incubated at $25^{\circ} \mathrm{C}, 37^{\circ} \mathrm{C}$ or $50^{\circ} \mathrm{C}$ corresponding to the optimal activity of the used enzymes. Most of the restriction enzymes can be heat inactivated at $65-80^{\circ} \mathrm{C}$ for $10-20$ min. Digested DNA was purified by using the PCR-Purification Kit from Qiagen.

\section{Klenow fragment (Fermentas):}

The Klenow fragment is a large fragment of the DNA Polymerase I of E.coli. It exhibits the 5'-3' polymerase activity, the 3' -5 ' exonuclease activity but lacks the 5'3' exonuclease activity. The Klenow fragment was used (instead of T4-Polymerase) to fill-up (blunt) sticky double strand DNA ends. 
Klenow reaction (standard example):

\begin{tabular}{|l|l|l|}
\hline Component & Concentration & Volume \\
\hline $\begin{array}{l}\text { Sample: } \\
\text { (2) PCR product }\end{array}$ & $2-5 \mu \mathrm{g} /$ Reaction & $30 \mu \mathrm{L}$ \\
\hline dNTPs & $2.5 \mathrm{mM}$ & $1 \mu \mathrm{L}$ \\
\hline Klenow buffer & $10 \mathrm{x}$ & $4 \mu \mathrm{L}$ \\
\hline Klenow fragment & $10 \mathrm{U} / \mu \mathrm{L}$ & $0.5 \mu \mathrm{L}$ \\
\hline dH2O & & $4.5 \mu \mathrm{L}$ \\
\hline Total & & $\mathbf{4 0} \mu \mathbf{L}$ \\
\hline
\end{tabular}

Table 5. Klenow reaction mix

Duration: $15 \mathrm{~min}$ at $\mathrm{RT}$, and $10 \mathrm{~min}$ heat inactivated at $70^{\circ} \mathrm{C}$. Blunted DNA was purified by using the PCR-Purification Kit from Qiagen.

CIAP (Calf Intestine Alkaline Phosphatase, Fermentas):

CIAP catalyzes the release of 5'- and 3'-phosphates from DNA, RNA, NTPs, dNTPs, and proteins.

$\underline{\text { Reaction (standard example): }}$

\begin{tabular}{|l|l|l|}
\hline Component & Concentration & Volume \\
\hline Sample: & $2-5 \mu \mathrm{g} /$ Reaction & $30 \mu \mathrm{L}$ \\
(2) PCR product & $10 \mathrm{x}$ & \\
\hline CIP reaction buffer & $10 \mathrm{U} / \mu \mathrm{L}$ & $1 \mu \mathrm{L}$ \\
\hline CIP enzyme & & $5 \mu \mathrm{L}$ \\
\hline dH2O & & $\mathbf{4 0} \boldsymbol{\mu L}$ \\
\hline Total & & $4 \mu \mathrm{L}$ \\
\hline
\end{tabular}

Table 6. CIAP reaction mix 
Duration: 30 min incubation at $37^{\circ} \mathrm{C}$ and heat inactivated at $85^{\circ} \mathrm{C}$. Modified DNA was purified by using the PCR-Purification Kit from Qiagen.

\subsubsection{Purification of linearized DNA or PCR products}

\section{Protocol:}

\begin{tabular}{|c|c|c|c|}
\hline Step & Description & Temp. & Time \\
\hline 1 & $\begin{array}{l}\text { Add } 5 \text { volumes of Buffer PB to } 1 \text { volume of the PCR sample and } \\
\text { mix. }\end{array}$ & RT & \\
\hline 2 & $\begin{array}{l}\text { Place a QIAquick spin column in a provided } 2 \mathrm{~mL} \text { collection tube } \\
\text { and apply the DNA on the column. Bind the DNA by centrifugation } \\
(13000 \mathrm{rpm}) .\end{array}$ & $\mathrm{RT}$ & $1 \mathrm{~min}$ \\
\hline 3 & $\begin{array}{l}\text { Discard the flow-through and place the QIAquick column back in } \\
\text { the same collection tube. }\end{array}$ & $\mathrm{RT}$ & \\
\hline 4 & $\begin{array}{l}\text { To wash, add } 750 \mu \mathrm{L} \text { of Buffer PE to the QIAquick column, wait } 5 \\
\text { min and centrifuge ( } 13000 \mathrm{rpm}) \text {. }\end{array}$ & RT & $1 \mathrm{~min}$ \\
\hline 5 & $\begin{array}{l}\text { Discard the flow-through and place the QIAquick column back in } \\
\text { the same collection tube and centrifuge again to remove residual PE } \\
\text { traces }(13000 \mathrm{rpm}) .\end{array}$ & $\mathrm{RT}$ & $2 \mathrm{~min}$ \\
\hline 6 & Place the QIAquick column into a clean $1.5 \mathrm{~mL}$ Eppendorf tube. & RT & \\
\hline 7 & $\begin{array}{l}\text { To elute DNA, add } 30-50 \mu \mathrm{L} \text { of Buffer EB }(10 \mathrm{mM} \text { Tris } \cdot \mathrm{Cl}, \mathrm{pH} \\
8.5) \text { to the center of the QIAquick membrane, wait for } 1-5 \mathrm{~min} \\
\text { and centrifuge the column ( } 13000 \mathrm{rpm}) \text {. }\end{array}$ & $\mathrm{RT}$ & $1.5 \mathrm{~min}$ \\
\hline
\end{tabular}




\subsubsection{DNA ligation reaction}

T4-DNA Ligase ligation:

\begin{tabular}{|l|l|l|}
\hline Component & Concentration & Volume \\
\hline Vector DNA & $100 \mathrm{ng} / \mu \mathrm{L}$ & $1 \mu \mathrm{L}$ \\
\hline Insert DNA & $100 \mathrm{ng} / \mu \mathrm{L}$ & $3 \mu \mathrm{L}$ \\
\hline $\begin{array}{l}\text { T4-ligation } \\
\text { buffer }\end{array}$ & $5 \mathrm{x}$ & $2 \mu \mathrm{L}$ \\
\hline dH2O & $1 \mathrm{U} / \mu \mathrm{L}$ & $3.5 \mu \mathrm{L}$ \\
\hline T4-DNA Ligase & & $0.5 \mu \mathrm{L}$ \\
(Invitrogen) & & $\mathbf{1 0} \mu \mathbf{L}$ \\
\hline Total & & \\
\hline Duration: 1-3 hours at RT or o/n at $15^{\circ} \mathrm{C}$ \\
\hline
\end{tabular}

Table 7. T4-Ligase reaction mix
pCR-TOPO ligation:

\begin{tabular}{|l|l|l|}
\hline Component & Concentration & Volume \\
\hline PCR product & $100 \mathrm{ng} / \mu \mathrm{L}$ & $2 \mu \mathrm{L}$ \\
\hline Salt solution & $1: 4$ dilution & $0.5 \mu \mathrm{L}$ \\
\hline $\begin{array}{l}\text { TOPO-system } \\
\text { mix (Invitrogen) }\end{array}$ & $0.5 \mu \mathrm{L}$ \\
\hline Total & & $\mathbf{3} \mu \mathbf{L}$ \\
\hline Duration: 20 min at RT & \\
\hline
\end{tabular}

Table 8. TOPO Ligation mix

\section{$\underline{6.10 .8 \quad \text { Competent Cells }}$}

A single colony of E.coli cells was inoculated in $10-15 \mathrm{~mL}$ LB-medium (+Tetracycline in the medium for the TOP $10 \mathrm{~F}^{\prime}$ cells) and grown over night $(\mathrm{o} / \mathrm{n})$, shaking $(200 \mathrm{rpm})$ at $37^{\circ} \mathrm{C}$.

$10 \mathrm{~mL} \mathrm{o} / \mathrm{n}$ grown bacteria were inoculated in $1 \mathrm{~L}$ of pre-warmed $\left(37^{\circ} \mathrm{C}\right) \mathrm{LB}$-medium and grown at $37^{\circ} \mathrm{C}$, shaking $250-300 \mathrm{rpm}$, to an $\mathrm{OD}_{600}$ of $=0.5-0.6$. The $\mathrm{OD}$ was measured by using a spectrophotometer at $600 \mathrm{~nm}$ (simply LB-medium was used for the blank-value). The cells got chilled on ice for 10 to $15 \mathrm{~min}$ and transferred to prechilled $0.5 \mathrm{~L}$ centrifuge bottles (cells were kept at $2^{\circ} \mathrm{C}$ for all subsequent steps).

Afterwards, the cells were centrifuged for $15 \mathrm{~min}$ at $5000 \mathrm{~g}$. The supernatant was poured off and the cells got re-suspended in $5 \mathrm{~mL}$ of pre-cooled fresh water, then the centrifuge bottles got filled up to $1 \mathrm{~L}$ before the centrifuge step above was repeated. The supernatant got immediately discharged following re-suspension of the pellet in 5 $\mathrm{mL}$ cold fresh water, then the centrifuge bottles got filled up to $500 \mathrm{~mL}$ before the centrifuge step above was repeated once more. The supernatant got decanted following the addition of $15 \mathrm{~mL} 10 \%$ cold glycerol and transferred into two $50 \mathrm{~mL}$ 
falcon-tubes to centrifuge again as mentioned before. The supernatant got discharged and the pellet was re-suspended in $2.5-3 \mathrm{~mL} 10 \%$ glycerol. $40-50 \mu \mathrm{L}$ aliquots of the competent cells were immediately thrown into a bucket with liquid nitrogen and frozen at $-80^{\circ} \mathrm{C}$.

\subsubsection{DNA transformation into bacteria strains (electro-competent cells)}

\section{Protocol:}

\begin{tabular}{|c|c|c|c|}
\hline Step & Description & Temp. & Time \\
\hline 1 & Thaw competent cells on ice. (one tube contains about $40-50 \mu \mathrm{L}$ ) & $4^{\circ} \mathrm{C}$ & \\
\hline 2 & $\begin{array}{l}\text { Add } 2 \mu \mathrm{L} \text { of pCR-TOPO-ligation or } 2-4 \mu \mathrm{L} \text { of T4-ligation to the } \\
\text { competent cells and mix thoroughly with a pipette tip. }\end{array}$ & $4^{\circ} \mathrm{C}$ & \\
\hline 3 & $\begin{array}{l}\text { Transfer the cell suspension including the DNA-ligation to a } \\
\text { electroporation cuvette and transform the cells by using the } \\
\text { MicroPulser of BioRad (Program EC2) }\end{array}$ & & \\
\hline 4 & $\begin{array}{l}\text { Add } 300 \mu \mathrm{L} \text { of LB-bacteria medium to the cells and transfer } \\
\text { everything into a pre-cooled Eppendorf tube. }\end{array}$ & $4^{\circ} \mathrm{C}$ & \\
\hline 5 & Store the tube including the transformed cells on ice. & $4^{\circ} \mathrm{C}$ & $2 \min$ \\
\hline 6 & Incubate the cells before plating. & $37^{\circ} \mathrm{C}$ & $30-60 \mathrm{~min}$ \\
\hline 7 & $\begin{array}{l}50-100 \mu \mathrm{L} \text { of the total } 300 \mu \mathrm{L} \text { got plated on a LB-bacteria plate } \\
\text { supplemented with Ampicillin (Ampicillin stock } 100 \mathrm{mg} / \mathrm{mL}=> \\
\text { final conc. } 1000 \mathrm{x} \text { diluted) }\end{array}$ & $37^{\circ} \mathrm{C}$ & $\mathrm{o} / \mathrm{n}$ \\
\hline
\end{tabular}

\subsubsection{Bacteria mini-culture and plasmid DNA isolation}

Single colonies of E.coli cells were picked with sterile pipette-tips were inoculated in LB-medium (Luria-Bertani medium) supplemented with Ampicillin $100 \mu \mathrm{g} / \mathrm{mL}(2-$ $3 \mathrm{~mL}$ for mini, $50-100 \mathrm{~mL}$ for midi) and grown over night $(\mathrm{o} / \mathrm{n})$, shaking $(200 \mathrm{rpm})$ at $37^{\circ} \mathrm{C}$. 


\section{Protocol (Plasmid DNA Purification Using the QIAprep Spin Miniprep Midiprep}

\section{Kit and a Microcentrifuge, according to Qiagen):}

Miniprep protocol is marked in red and the Midiprep protocol in blue. Step 1-4 are common for both applications.

\begin{tabular}{|c|c|c|c|}
\hline Step & Description & Temp. & Time \\
\hline 1 & $\begin{array}{l}\text { Transfer the bacteria culture in Eppendorf-tubes/Falcon-Tubes and } \\
\text { centrifuge the bacteria culture at } 5000 \mathrm{rpm} / 4000 \mathrm{rpm} \text { and discard the } \\
\text { supernatant. }\end{array}$ & RT & $5-10 \mathrm{~min}$ \\
\hline 2 & $\begin{array}{l}\text { Resuspend the pelleted bacterial cells in } 250 \mu \mathrm{L} / 6 \mathrm{~mL} \text { Buffer P1 } \\
\text { (includes RNase A) by vortexing. }\end{array}$ & RT & $1-2 \min$ \\
\hline 3 & $\begin{array}{l}\text { Add } 250 \mu \mathrm{L} / 6 \mathrm{~mL} \text { Buffer } \mathrm{P} 2 \text { and mix thoroughly by inverting the } \\
\text { tube } 4-6 \text { times. }\end{array}$ & RT & $\begin{array}{l}\max . \\
5 \mathrm{~min}\end{array}$ \\
\hline 4 & $\begin{array}{l}\text { Add } 350 \mu \mathrm{L} / 6 \mathrm{~mL} \text { chilled Buffer } \mathrm{N} 3 / \mathrm{P} 3 \text { and mix immediately and } \\
\text { thoroughly by inverting the tube } \\
4-6 \text { times. Incubate the reaction. }\end{array}$ & RT & $5 \min$ \\
\hline 5 & Centrifuge at $13,000 \mathrm{rpm}$. & RT & $10 \mathrm{~min}$ \\
\hline 6 & $\begin{array}{l}\text { To bind the DNA, apply the supernatants from step } 5 \text { to the } \\
\text { QIAprep spin column by decanting or pipetting and let the column } \\
\text { soak. }\end{array}$ & RT & $5 \mathrm{~min}$ \\
\hline 7 & Centrifuge at max. speed and discard the flow-through. & RT & $30-60 \mathrm{~s}$ \\
\hline 8 & $\begin{array}{l}\text { Wash QIAprep spin column by adding } 750 \mu \mathrm{L} \text { Buffer PE, wait } 5 \\
\text { min and centrifuging at max speed. }\end{array}$ & RT & $30-60 \mathrm{~s}$. \\
\hline 9 & $\begin{array}{l}\text { Discard the flow-through, and centrifuge again to remove residual } \\
\text { wash buffer. }\end{array}$ & RT & $2 \min$ \\
\hline 10 & $\begin{array}{l}\text { Place the QIAprep column in a clean } 1.5 \mathrm{~mL} \text { Eppendorf-tube. To } \\
\text { elute DNA, add } 50 \mu \mathrm{L} \text { Buffer EB }(10 \mathrm{mM} \text { Tris } \cdot \mathrm{Cl}, \mathrm{pH} 8.5) \text { to the } \\
\text { center of the QIAprep spin column, let stand for } 5 \mathrm{~min} \text {, and } \\
\text { centrifuge }(13000 \mathrm{rpm}) \text {. }\end{array}$ & RT & $2 \min$ \\
\hline 5 & $\begin{array}{l}\text { Pour the lysate into the barrel of the QIAfilter Cartridge and } \\
\text { incubate. Do not insert the plunger! }\end{array}$ & RT & $10 \mathrm{~min}$ \\
\hline 6 & $\begin{array}{l}\text { Equilibrate a HiSpeed Midi Tip by applying } 4 \mathrm{~mL} \text { QBT Buffer and } \\
\text { allow the column to empty by gravity flow. }\end{array}$ & RT & \\
\hline
\end{tabular}




\begin{tabular}{|c|c|c|c|}
\hline 7 & $\begin{array}{l}\text { Insert the plunger into the QIAfilter Cartridge and filter the cell } \\
\text { lysate into the previously equilibrated HiSpeed Tip. Allow the } \\
\text { cleared lysate to enter the resin by gravity flow. }\end{array}$ & $\mathrm{RT}$ & \\
\hline 8 & $\begin{array}{l}\text { Wash the HiSpeed Midi Tip with } 20 \mathrm{~mL} \text { Buffer QC. Allow Buffer } \\
\text { QC to move through the HiSpeed Tip by gravity flow. }\end{array}$ & $\mathrm{RT}$ & \\
\hline 9 & $\begin{array}{l}\text { Elute DNA with } 5 \mathrm{ml} \text { Buffer QF. Collect the eluate in a tube with a } \\
\text { minimum capacity of } 10 \mathrm{~mL} \text {. }\end{array}$ & RT & \\
\hline 10 & $\begin{array}{l}\text { Precipitate DNA by adding } 3.5 \mathrm{~mL}(0.7 \text { volumes }) \text { roomtemperature } \\
\text { isopropanol to the eluted DNA. Mix and incubate. }\end{array}$ & $\mathrm{RT}$ & $5 \mathrm{~min}$ \\
\hline 11 & $\begin{array}{l}\text { During the incubation, attach a } 20 \mathrm{~mL} \text { syringe to the } \\
\text { QIAprecipitator Midi Module. }\end{array}$ & $\mathrm{RT}$ & \\
\hline 12 & $\begin{array}{l}\text { Transfer the eluate/isopropanol mixture into the } 20 \mathrm{~mL} \text { syringe and } \\
\text { filter the mixture through the QIAprecipitator using constant } \\
\text { pressure. }\end{array}$ & $\mathrm{RT}$ & \\
\hline 13 & $\begin{array}{l}\text { Add } 2 \mathrm{~mL} 70 \% \text { ethanol to the syringe and wash the DNA by } \\
\text { pressing the ethanol through the QIAprecipitator using constant } \\
\text { pressure. }\end{array}$ & $\mathrm{RT}$ & \\
\hline 14 & $\begin{array}{l}\text { Dry the membrane by pressing air through the QIAprecipitator } \\
\text { quickly and forcefully. Repeat this step. }\end{array}$ & $\mathrm{RT}$ & \\
\hline 15 & $\begin{array}{l}\text { To elute the DNA, add } 200-400 \mu \mathrm{L} \text { of Buffer } \mathrm{EB}(10 \mathrm{mM} \text { Tris } \cdot \mathrm{Cl} \text {, } \\
\mathrm{pH} 8.5) \text { to syringe/QIAprecipitator, and collect the DNA in a } 1.5 \\
\mathrm{~mL} \text { Eppendorf-tube. }\end{array}$ & $\mathrm{RT}$ & $1.5 \mathrm{~min}$ \\
\hline
\end{tabular}




\subsubsection{Ultrapure DNA for transgenesis}

Protocol (Plasmid DNA Purification Using the EndoFree Plasmid Maxi Kit, according to Qiagen):

\begin{tabular}{|c|c|c|c|}
\hline Step & Description & Temp. & Time \\
\hline 1 & $\begin{array}{l}\text { Transfer the bacteria culture in Falcon-Tubes and centrifuge the } \\
\text { bacteria culture at } 4000 \mathrm{rpm} \text { and discard the supernatant. }\end{array}$ & RT & $5-10 \mathrm{~min}$ \\
\hline 2 & $\begin{array}{l}\text { Resuspend the pelleted bacterial cells in } 10 \mathrm{~mL} \text { Buffer P1 (includes } \\
\text { RNase A) by vortexing. }\end{array}$ & RT & $1-2 \mathrm{~min}$ \\
\hline 3 & $\begin{array}{l}\text { Add } 10 \mathrm{~mL} \text { Buffer P2 and mix thoroughly by inverting the tube } 4-6 \\
\text { times. }\end{array}$ & $\mathrm{RT}$ & $\begin{array}{l}\max . \\
5 \mathrm{~min}\end{array}$ \\
\hline 4 & $\begin{array}{l}\text { Add } 10 \mathrm{~mL} \text { chilled Buffer } \mathrm{P} 3 \text { and mix immediately and thoroughly } \\
\text { by inverting the tube } 4-6 \text { times. Incubate the reaction. }\end{array}$ & RT & $5 \mathrm{~min}$ \\
\hline 5 & $\begin{array}{l}\text { Pour the lysate into the barrel of the QIAfilter Cartridge and } \\
\text { incubate. Do not insert the plunger! }\end{array}$ & RT & $10 \mathrm{~min}$ \\
\hline 6 & $\begin{array}{l}\text { Gently insert the plunger into the QIAfilter Maxi Cartridge and } \\
\text { filter the cell lysate into a } 50 \mathrm{ml} \text { tube. }\end{array}$ & RT & \\
\hline 7 & $\begin{array}{l}\text { Add } 2.5 \mathrm{~mL} \text { Buffer ER to the filtered lysate, mix by inverting the } \\
\text { tube approximately } 10 \text { times, and incubate on ice. }\end{array}$ & $4^{\circ} \mathrm{C}$ & $30 \mathrm{~min}$ \\
\hline 8 & $\begin{array}{l}\text { Equilibrate a QIAGEN-tip } 500 \text { by applying } 10 \mathrm{~mL} \text { Buffer QBT, and } \\
\text { allow the column to empty by gravity flow. }\end{array}$ & RT & \\
\hline 9 & $\begin{array}{l}\text { Apply the filtered lysate from step } 7 \text { to the QIAGEN-tip and allow } \\
\text { it to enter the resin by gravity flow. }\end{array}$ & RT & \\
\hline 10 & $\begin{array}{l}\text { Wash the QIAGEN-tip with } 2 \text { x } 30 \mathrm{~mL} \text { Buffer QC. Allow Buffer } \\
\text { QC to move through the QIAGEN-tip by gravity flow. }\end{array}$ & RT & \\
\hline 11 & $\begin{array}{l}\text { Elute DNA with } 15 \mathrm{~mL} \text { Buffer QN. Collect the eluate in a } 30 \mathrm{~mL} \\
\text { endotoxin-free or pyrogen-free tube. }\end{array}$ & RT & \\
\hline 10 & $\begin{array}{l}\text { Precipitate DNA by adding } 10.5 \mathrm{ml} \text { ( } 0.7 \text { volumes }) \text { isopropanol to } \\
\text { the eluted DNA. Mix and centrifuge immediately at } 8500 \mathrm{rpm} \text {. }\end{array}$ & $4^{\circ} \mathrm{C}$ & $30 \mathrm{~min}$ \\
\hline 11 & $\begin{array}{l}\text { Wash DNA pellet with } 5 \mathrm{~mL} \text { of endotoxin-free } 70 \% \text { ethanol (add } \\
40 \mathrm{ml} \text { of } 96-100 \% \text { ethanol to the endotoxin-free water supplied } \\
\text { with the kit) and centrifuge at } 8500 \mathrm{rpm} \text {. }\end{array}$ & RT & $10 \mathrm{~min}$ \\
\hline 12 & $\begin{array}{l}\text { Air-dry the pellet for 5-10 min, and redissolve the DNA in } 200 \mu \mathrm{L} \\
\text { endotoxin-free Buffer TE. }\end{array}$ & RT & \\
\hline
\end{tabular}




\subsubsection{Diagnostic Restriction digest to verify plasmid DNA}

Reaction (standard example):

\begin{tabular}{|l|l|l|}
\hline Component & Concentration & Volume \\
\hline Plasmid-DNA & $200-400 \mathrm{ng}$ & $1-3 \mu \mathrm{L}$ \\
\hline Reaction buffer & $10 \mathrm{x}$ & $2 \mu \mathrm{L}$ \\
\hline BSA (optional) & $100 \mathrm{x}$ & $0.2 \mu \mathrm{L}$ \\
\hline Enzyme & $5-20 \mathrm{U} / \mu \mathrm{L}$ & $0.3 \mu \mathrm{L}$ per enzyme \\
\hline dH2O & & $14.5-16.5 \mu \mathrm{L}$ \\
\hline Total & & $\mathbf{2 0} \boldsymbol{\mu L}$ \\
\hline
\end{tabular}

Table 9. Diagnostic restriction enzyme mix

\section{$\underline{6.10 .13}$ Sequencing of plasmid DNA}

Plasmids used for this work were verified by sequencing performed by Seqlab (Göttingen, Germany) and MWG (Ebersberg, Germany).

\subsubsection{Sense- and anti-sense RNA production}

\section{Sense RNA:}

First, purified Midi plasmid-DNA was linearized as described in chapter 6.10.5 to produce the template for sense RNA. The Message machine kit (Ambion) was used to produce capped sense RNA for injection. 


\section{1.) Set up the transcription reaction mix}

Sense RNA reaction:

\begin{tabular}{|l|l|l|}
\hline Component & Concentration & Volume \\
\hline Linearized DNA & $50-500 \mathrm{ng}$ & $1-3 \mu \mathrm{L}$ \\
\hline NTP mix, Cap analog & $2 \mathrm{x}$ & $5 \mu \mathrm{L}$ \\
\hline GTP (optional for long transcripts only) & & $1 \mu \mathrm{L}$ \\
\hline T3, T7 or SP6 buffer & $10 \mathrm{x}$ & $1 \mu \mathrm{L}$ \\
\hline dH2O & & variable \\
\hline T3, T7 or SP6 RNA-Polymerase & $1 \mathrm{U} / \mu \mathrm{L}$ & $0.8 \mu \mathrm{L}$ \\
\hline Total & & $\mathbf{1 0} \mu \mathbf{L}$ \\
\hline Duration: $2-3.5$ hours at $37^{\circ} \mathrm{C}$ & \\
\hline Table $10 . \quad$ sense RNA reaction mix & \\
\hline
\end{tabular}

\section{2.) Removal of the template}

add $0,5 \mu \mathrm{L}$ DNAseI (Ambion), mix well and incubate for $20 \mathrm{~min}$ at $37^{\circ} \mathrm{C}$

\section{3.) Phenol-Chloroform extraction}

1) add $260 \mu \mathrm{L}$ DEPC water (AppliChem) to the sense reaction

2) add $30 \mu \mathrm{L}$ Ammonium Acetate Stop Solution (Message Machine Kit)

3) add $300 \mu \mathrm{L}$ PCI (Phenol-Chloroform-Isoamylalcohol, 25: $24: 1, \mathrm{pH}=6,6$, Ambion)

4) vortex for about $10 \mathrm{~s}$, spin for $15 \mathrm{~min}$ at $13000 \mathrm{rpm}$ at RT

5) carefully transfer the upper phase to a new Eppendorf tube and discard the lower phase.

6) add $300 \mu \mathrm{L}$ CI (Chloroform-Isoamylalcohol, 24:1), shake vigorously and spin for $7 \mathrm{~min}$ at $13000 \mathrm{rpm}$ at RT

7) transfer the upper phase to new Eppendorf tube

8) repeat step $5-7$ again 


\section{4.) Precipitation}

1) add equal volume of $100 \%$ Isopropanol

2) centrifuge immediately for $40 \mathrm{~min}$ at $13000 \mathrm{rpm}$., cool down to $4^{\circ} \mathrm{C}$ while spinning

3) carefully remove the supernatant

4) wash $2 \mathrm{x}$ with $80 \% \mathrm{EtOH}$

5) after the second wash, remove large drops and air dry the RNA pellet for a minimum time

6) dissolve the RNA in $20 \mu \mathrm{L}$ HEPES (10mM, pH 7,4, DEPC water)

\section{5.) Analysis of the RNA}

- Spectrophotometer:

dissolve $1 \mu \mathrm{L}$ in $99 \mu \mathrm{L}$ DEPC water, use the RNA mode of the spectrometer

- Agarose gel:

$1 \mu \mathrm{L}$ RNA $+1 \mu \mathrm{L}$ Ambion RNA loading buffer

heat the mixture for $3 \mathrm{~min}$ at $85^{\circ} \mathrm{C}$, put on ice for $2 \mathrm{~min}$ and load the gel 
Antisense RNA:

First, purified Midi plasmid-DNA was linearized as described in chapter 6.10 .5 to produce the template for anti-sense RNA.

\section{1.) Set up the anti-sense reaction mix}

Anti-sense RNA reaction:

\begin{tabular}{|l|l|l|}
\hline Component & Concentration & Volume \\
\hline Linearized DNA & $500-1000 \mathrm{ng}$ & $2 \mu \mathrm{L}$ \\
\hline $\begin{array}{l}\text { Dig- or Fluo- } \\
\text { labeled NTPs }\end{array}$ & $10 \mathrm{x}$ & $2 \mu \mathrm{L}$ \\
\hline $\begin{array}{l}\text { T3, T7 or SP6 } \\
\text { buffer }\end{array}$ & $5 \mathrm{x}$ & $4 \mu \mathrm{L}$ \\
\hline RNAse Inhibitors & & $1 \mu \mathrm{L}$ \\
\hline dH2O & & variable \\
\hline $\begin{array}{l}\text { T3, T7 or SP6 } \\
\text { RNA-Polymerase }\end{array}$ & $1 \mathrm{U} / \mu \mathrm{L}$ & $2 \mu \mathrm{L}$ \\
\hline Total & & $\mathbf{2 0} \mu \mathbf{L}$ \\
\hline Duration: $2-3.5$ hours at $37^{\circ} \mathrm{C}$ & \\
\hline
\end{tabular}

Preparation of the 10x NTP-Mix:

- Roche:

pre-mixed Dig-or Fluo-labeled NTP-Mixes

- Lab mix: $(50 \mu 1)$

ATP (Stock: $100 \mathrm{mM}): \quad 5 \mu \mathrm{l}$ final conc. $=10 \mathrm{mM}$

GTP (Stock: $100 \mathrm{mM}$ ): $\quad 5 \mu \mathrm{l}$ final conc. $=10 \mathrm{mM}$

CTP (Stock: $100 \mathrm{mM})$ : $\quad 5 \mu \mathrm{l}$ final conc. $=10 \mathrm{mM}$
Stock: $100 \mathrm{mM}):$

UTP (Stock: $100 \mathrm{mM})$ : final conc. $=6,5 \mathrm{mM}$

Dig- or Fluo-UTP (Stock: $10 \mathrm{mM}$ ): $17,5 \mu 1 \quad$ final conc. $=3,5 \mathrm{mM}$ $\mathrm{H}_{2} \mathrm{O}$ (can be DEPC- $\mathrm{H}_{2} \mathrm{O}$ ): $14,25 \mu 1$

Table 11. Anti-sense RNA reaction mix

\section{2.) Removal of the template}

add $1 \mu \mathrm{L}$ of DNAse I (Ambion), mix well and incubate for $30 \mathrm{~min}$ at $37^{\circ} \mathrm{C}$

\section{3.) $\mathrm{NH}_{4}$ Ac-Precipitation}

1) add $11 \mu \mathrm{L}$ of $\mathrm{NH}_{4} \mathrm{Ac}(7,8 \mathrm{M})$

2) add $63 \mu \mathrm{L}$ of $100 \% \mathrm{EtOH}$

3) mix well by using the vortex and spin at $13000 \mathrm{rpm}$ at RT

4) let the RNA precipitate for 30 - 50 min at RT (keep dark)

5) discard supernatant

6) wash the RNA pellet $1 \mathrm{x}$ with $1 \mathrm{~mL} 80 \% \mathrm{EtOH}$ at RT

7) $\operatorname{spin}$ for $5-10 \mathrm{~min}$ at $13000 \mathrm{rpm}$

8) discard supernatant 
9) remove big residual drops and air dry the RNA pellet for a minimum time

10) dissolve the RNA in $20 \mu \mathrm{L} \mathrm{H}_{2} \mathrm{O}+80 \mu \mathrm{L}$ Hyb-buffer

\section{4.) Analysis of the RNA}

- Agarose gel:

$3 \mu \mathrm{L}$ RNA $+3 \mu \mathrm{L}$ Ambion RNA loading buffer

heat the mixture for $3 \mathrm{~min}$ at $85^{\circ} \mathrm{C}$, put on ice for $2 \mathrm{~min}$ and load the gel

\subsection{Zebrafish - experimental animal model}

\section{$\underline{6.11 .1 \quad \text { Zebrafish strain and fish maintenance }}$}

Zebrafish (Danio rerio) of the $\mathrm{AB}$ genetic background were maintained, raised and staged as previously described in (Westerfield, 1995) and (Kimmel et al., 1995).

\subsubsection{Injection of sense RNA, dyes and drugs into the zebrafish embryo}

Injection protocol:

The day before injection:

- set-up 1 L of $0.3 x$ Danieau's solution (for pouring and overlaying the injection ramps where the embryos are placed during the injection)

- set-up fish: fill tanks with water from the fish-facility and bring one female and one male together in one tank but they have to be divided by the separation inserts (mesh).

The day of injection:

- Dilute RNA/DNA in HEPES $(10 \mathrm{mM})$ to the appropriate concentration and keep on ice.

- Add Penicillin/Streptomycin $(\mathrm{P} / \mathrm{S})$ to $0.3 \mathrm{x}$ Danieau's solution and use it to exchange the $0.3 x$ Danieau's solution on the ramps from the day before.

- cross the fish-couple by removing the inserts (mesh) which separates the female from the male. One mesh remains in the tank, which will keep the fish away from already laid eggs. 
- after a couple laid eggs collect the clutch in a tea strainer and transfer the eggs in a clean petridish containing $1 \mathrm{x}$ methylene blue/egg water solution.

- collect the embryos using a pasteur pipette and transfer them into the ramps (overlayed with fresh $0.3 x$ Danieau's solution $\mathrm{P} / \mathrm{S}$ ) and use the metal needle to orient the embryos in the ramps.

- $\quad$ cut the tip of the glass-needle off with a scalpel and load the sample into the injection-needle

- the injection itself: pierce the chorion membrane and inject DNA only into the cell directly (do not inject DNA into the yolk). RNA can be inject into the yolk or the cell. The RNA will get into the cell by streaming from the yolk.

- $\quad$ after finishing the injection: get the embryos out of the ramps and transfer them (not more than 50-80 embryos) into a new clean petridish containing 0.3x Danieau's solution with $\mathrm{P} / \mathrm{S}$.

- transfer the embryos into the appropriate incubator $\left(25^{\circ} \mathrm{C}, 28^{\circ} \mathrm{C}\right.$ or $\left.30^{\circ} \mathrm{C}\right)$

- $\quad$ after 2-3 hours take a look to the embryos and place the fertilized into a new petridish with $0.3 \mathrm{x}$ Danieau's solution $\mathrm{P} / \mathrm{S}$. Incubate them further at $25^{\circ} \mathrm{C}-30^{\circ} \mathrm{C}$.

Progress to perform live imaging of embryos:

- chorions which surround the embryo are removed by hand (forcepts) and embryos are transferred and oriented into small agarose ramps.

Progress to grow embryos until adulthood:

- on the next morning sort again and transfer 'good one's' into methylene blue/egg water solution (blue water, prevent fungi from growing).

- $\quad$ after 5 days put them into the fish-facility system for growing. 
Reagents/Materials for injection:

\begin{tabular}{|c|c|}
\hline \multicolumn{2}{|l|}{ 30x Danieau's solution pH 7.6 (stock solution): } \\
\hline Reagents & for 1 liter \\
\hline $1.74 \mathrm{M} \mathrm{NaCl}(\mathrm{MW}=58.44 \mathrm{~g} / \mathrm{mol})$ & $101.7 \mathrm{~g}$ \\
\hline $21 \mathrm{mM} \mathrm{KCl}(\mathrm{MW}=74.56 \mathrm{~g} / \mathrm{mol})$ & $1.57 \mathrm{~g}$ \\
\hline $12 \mathrm{mM} \mathrm{MgSO}_{4}\left[7 \mathrm{H}_{2} \mathrm{O}\right](\mathrm{MW}=246.48 \mathrm{~g} / \mathrm{mol})$ & $2.96 \mathrm{~g}$ \\
\hline $\left.18 \mathrm{mM} \mathrm{Ca}\left(\mathrm{NO}_{3}\right) 2\left[4 \mathrm{H}_{2} \mathrm{O}\right)\right](\mathrm{MW}=236.15 \mathrm{~g} / \mathrm{mol})$ & $4.25 \mathrm{~g}$ \\
\hline $150 \mathrm{mM}$ HEPES $(\mathrm{MW}=238.31 \mathrm{~g} / \mathrm{mol})$ & $35.75 \mathrm{~g}$ \\
\hline
\end{tabular}

\section{Ramps:}

Set them up on the day before injection! Use a Erlenmeyer flask (should not been

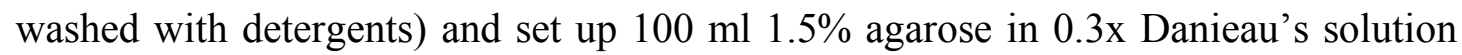
(this agarose should only be used for this purpose) sufficient for pouring 3-4 ramps. Place the ramp template (contains 6 rows for about 50 embryos each) carefully in the center of the petridish and avoid making bubbles. Remove the ramp template carefully when the agarose becomes solid. Overlay the agarose with $0.3 x$ Danieau's solution to prevent it from getting dried. Longer storage should be at $4^{\circ} \mathrm{C}$ with $0.3 \mathrm{x}$ Danieau's solution on top.

HEPES:

Stock solution: $500 \mathrm{mM}, \mathrm{pH} 7.4$

(HEPES, sodium salt; MW = 260,28 g/mol)

Working solution for

RNA/DNA injections: 10 mM HEPES, pH 7.4

Pen/Strep stock solution (penicillin and streptomycin):

Add 2 tubes of stock solution $(2.5 \mathrm{ml}$ each, 100x Pen/Strep concentration, final concentration $0.5 \mathrm{x}$ ) into 1 liter of $0.3 \mathrm{x}$ Danieau's solution. 


\section{RNA/DNA injection:}

Work was done always on ice!

Dilute RNA to a concentration of $50-200 \mathrm{ng} / \mu \mathrm{L}$ in HEPES $10 \mathrm{mM}, \mathrm{pH}$ 7.4. By using concentrations over $200 \mathrm{ng} / \mu \mathrm{L}$ it will become more and more toxic for the embryo. Before use, centrifuge the diluted RNA at maximum speed in a conventional tabletop microcentrifuge for a minimum of $10 \mathrm{~min}$.

Before use, centrifuge the DNA in a Spin-X tube (contains a $0.45 \mu \mathrm{m}$ cellulose acetate filter) at maximum speed in a conventional tabletop microcentrifuge for $1 \mathrm{~min}$. and transfer it into a new clean tube. Dilute DNA to a concentration of 5-50 ng/ $\mu \mathrm{L}$ in HEPES $10 \mathrm{mM}$, pH 7.4. If needed mix the DNA with RNA to the right concentration and spin down at maximum speed in a conventional tabletop microcentrifuge for a minimum of $10 \mathrm{~min}$.

\section{Injection needles:}

To inject the RNA/DNA into the embryos one has to prepare injection needles with the needle puller. Use a sharp scalpel to cut off the tip of the needle.

Generation of needles with an almost defined opening-width:

- $\quad$ cut the tip of the needle

- $\quad$ put a drop (20-50 $\mu 1)$ DEPC-water into a clean small petridish

- place the needle into the needle holder of the micromanipulator

- $\quad$ adjust pressure of the pneumatic picopump to 15 to 20 psi

- place the tip of the needle in the waterdrop

- $\quad$ the psi value at which air-bubbles will just leave the needle gives you an approximate estimation of the opening of the needle for example: is it a value around 15 psi the opening is wider than it is the case at a value around 20

Choose a value, which is appropriate for your experiment. 
Methylene blue solution and egg water (blue water):

salt/water solution containing methylene blue (prevents contamination with fungi)

- $\quad$ stock solution of methylene blue:

add $1 \mathrm{~g}$ methylene blue to 1 liter reverse osmosis water

- $\quad 4 x$ methylene blue/egg water solution:

add $20 \mathrm{ml}$ of methylene stock solution to 10 liter egg water

- $1 x$ methylene blue/egg water ready-to-use solution:

add $250 \mathrm{ml} \mathrm{4x}$ methylene blue solution to $750 \mathrm{ml}$ egg water

\section{$\underline{6.11 .3 \quad \text { Fixation of embryos }}$}

For in situ hybridization:

- Embryos $24 \mathrm{hpf}$ and older: chorion was removed by using forceps before fixation. Fixation overnight at $4^{\circ} \mathrm{C}$ in $4 \%$ PFA in PBS.

- Embryos younger than 1-2 somite stage were fixed for 2 days.

After fixation the embryos were rinsed 2-3 times in PBT and the chorion was removed by using forceps.

- Embryos got transferred to $100 \% \mathrm{MeOH}$ by passing them through a gradient of $\mathrm{MeOH} / \mathrm{PBT} ; 25 \%, 50 \%, 75 \%$ and $100 \%$.

- Embryos were stored in $100 \% \mathrm{MeOH}$ at $-20^{\circ} \mathrm{C}$ for several weeks or months.

For immunohistochemistry:

- chorion was removed with forceps before fixation. Embryos were transferred in pre-warmed (RT) PFA (4\%) in PBS and fixed for 2-3 $\mathrm{h}$ at RT. 


\subsubsection{In situ hybridization of whole mount zebrafish embryos}

One- and two-colour whole-mount in situ hybridization was performed as described previously (Jowett and Lettice, 1994) with modifications described elsewhere (Hauptmann and Gerster, 1994) and (Weidinger et al., 2002). To perform double staining in situ hybridization with a mix of different Dig- and Fluo-labeled probes, the antibody- and subsequent staining-steps are performed individually because both antibodies are coupled to the same enzyme (alkaline phosphatase). This enzyme was used with different dye combinations, here we used X-phosphate/NBT (blue) and Xphosphate/INT (red). Doing the blue staining as a first step has the advantage that the embryos can be cleared in EtOH (reduces dark background in the yolk) before the second antibody application.

\section{In situ Day 1:}

\begin{tabular}{|c|c|c|c|}
\hline Step & Description & Temp. & Time \\
\hline 1 & Rehydration $75 \% \mathrm{MetOH}-25 \%$ PBT & RT & $5 \mathrm{~min}$ \\
\hline 2 & Rehydration $50 \%$ MetOH - 50\% PBT & RT & $5 \min$ \\
\hline 3 & Rehydration $25 \%$ MetOH - 75\% PBT & RT & $5 \min$ \\
\hline 4 & Rehydration $100 \%$ PBT & RT & $4 \times 5 \min$ \\
\hline 5 & $\begin{array}{l}\text { Proteinase } \mathrm{K}(5 \mu \mathrm{g} / \mathrm{ml} \text { in PBT }) \text { : } \\
\text { - before shield: no treatment } \\
\text { - shield - bud: } 0 \text { - } 30 \mathrm{sec} \\
\text { - } 1 \text { somite: } 30 \text { - } 60 \mathrm{sec} \\
\text { - } 5 \text { somite: } 3 \text { - } 4 \text { min } \\
\text { - } 24 \text { hpf embryo: } 4 \text { - } 5 \mathrm{~min} \\
\text { - } 36 \text { - } 72 \text { hpf embryo: } 10 \text { - } 20 \text { min with } 10 \mu \mathrm{g} / \mathrm{ml}\end{array}$ & RT & \\
\hline 6 & PBT & RT & $10 \mathrm{~s}$ \\
\hline 7 & PBT & RT & $10 \mathrm{~s}$ \\
\hline 8 & PBT & RT & $1 \mathrm{~min}$ \\
\hline
\end{tabular}




\begin{tabular}{l|l|l|l}
\hline 9 & PBT & RT & $5 \mathrm{~min}$ \\
\hline 10 & Refixation in 4\% PFA in PBS & RT & $20 \mathrm{~min}$ \\
\hline 11 & Wash in PBT & RT & $5 \times 5 \mathrm{~min}$ \\
\hline 12 & Prehybridization: incubate in $200 \mu \mathrm{L}$ of $\mathrm{Hyb}$-buffer & $67^{\circ} \mathrm{C}$ & $2-5 \mathrm{~h}$ \\
\hline 13 & $\begin{array}{l}\text { Hybridization: } 0,5 \mu \mathrm{L}-3 \mu \mathrm{L} \text { of antisense probe in } 200 \mu \mathrm{lof} \mathrm{Hyb}- \\
\text { buffer to replace the prehybridization. } \\
\text { Heat the hybridization mix to } 67^{\circ} \mathrm{C} \text { (water bath) for about } 10 \mathrm{~min} .\end{array}$ & $67^{\circ} \mathrm{C}$ & $12 \mathrm{~h}$ \\
\hline
\end{tabular}

$\underline{\text { Solutions: }}$

\section{PBS 10x for $1 \mathrm{~L}$}

$-80 \mathrm{~g} \mathrm{NaCl}$

$-2 \mathrm{~g} \mathrm{KCl}$

- $18 \mathrm{~g} \mathrm{Na}_{2} \mathrm{HPO}_{4}\left(2 \mathrm{H}_{2} \mathrm{O}\right)$

$-2,4 \mathrm{~g} \mathrm{KH}_{2} \mathrm{PO}_{4}$

- adjust to $\mathrm{pH} 7,2$

\section{PBT $1 x$ for $1 \mathrm{~L}$}

- 100 ml 10x PBS

- $900 \mathrm{ml} \mathrm{H} \mathrm{H}_{2} \mathrm{O}$

- adjust to $\mathrm{pH}$ 7,4 (by adding 15\% $\mathrm{HCl}$ )

- add $10 \mathrm{ml} \mathrm{10 \%} \mathrm{Tween20}$

$\underline{\text { SSC } 20 x \text { for } 8 \mathrm{~L}}$

$-1400 \mathrm{~g} \mathrm{NaCl}$

- 704 g Trisodium Citrate[2 $\left.\mathrm{H}_{2} \mathrm{O}\right]$

- adjust to $\mathrm{pH} 7,0$ (by adding $15 \% \mathrm{HCl}$ ) 
Hyb-buffer for $1 \mathrm{~L}$

$-250 \mathrm{ml} 20 \mathrm{x}$ SSC

- $500 \mathrm{mg}$ tRNA* (Sigma)

- 50 mg Heparin (Sigma)

- $10 \mathrm{ml} \mathrm{10 \%} \mathrm{Tween20} \mathrm{(Sigma)}$

- 1,89 g Citric Acid (Monohydrate) to $\mathrm{pH}$ 6,0 - 6,5

$-\mathrm{H}_{2} \mathrm{O}$ to $500 \mathrm{~mL}$

- last: add $500 \mathrm{~mL}$ deionized formamide

- store at $-20^{\circ} \mathrm{C}$

* Rnase free tRNA: torula yeast RNA (Sigma R6625)

- $500 \mathrm{mg}$ tRNA in $20 \mathrm{~mL}$ 10x SSC extracted with Phenol/Chloroform -

Chloroform/Isoamylalcohol (see protocol for purifying sense or antisense RNA)

- after $2 \mathrm{x}$ wash with $80 \% \mathrm{EtOH}$, air dry and resuspend in $5 \mathrm{~mL} \mathrm{10x} \mathrm{SSC}$

\section{In situ Day 2:}

- Recover the probes!

- Always preheat the washing solutions to hybridization temperature!

\begin{tabular}{|c|c|c|c|}
\hline Step & Description & Temp. & Time \\
\hline 1 & Wash with Hyb-buffer & $67^{\circ} \mathrm{C}$ & $20 \mathrm{~min}$ \\
\hline 2 & Wash with 50\% SSCT 2x / 50\% Formamide & $67^{\circ} \mathrm{C}$ & $3 \times 20 \mathrm{~min}$ \\
\hline 3 & Wash with $75 \%$ SSCT $2 \times / 25 \%$ Formamide & $67^{\circ} \mathrm{C}$ & $20 \mathrm{~min}$ \\
\hline 4 & Wash with SSCT $2 \mathrm{x}$ & $67^{\circ} \mathrm{C}$ & $2 \times 20 \mathrm{~min}$ \\
\hline 5 & Wash with SSCT $0.2 x$ & $67^{\circ} \mathrm{C}$ & $4 \times 30 \min$ \\
\hline 6 & PBT & $67^{\circ} \mathrm{C}$ & $5 \min$ \\
\hline 7 & $\begin{array}{l}\text { Blocking: } 5 \% \text { sheep serum }+10 \mathrm{mg} / \mathrm{ml} \mathrm{BSA} \text { in PBT } \\
\text { Slow agitation and keep dark }\end{array}$ & $\mathrm{RT}$ & $>1 \mathrm{~h}$ \\
\hline 8 & $\begin{array}{l}\text { Antibody-incubation I: Incubate in } 100-200 \mu \mathrm{L} \text { antibody solution. } \\
\text { Antiserum pre-absorbed against embryos, } 1: 2000-1: 4000 \text { in PBT }+ \\
2 \mathrm{mg} / \mathrm{mL} \text { BSA (optional: }+2 \% \text { sheep serum). For storage at } 4^{\circ} \mathrm{C} \text { : } \\
\text { add Sodium Azide to } 0,02 \%\end{array}$ & $4^{\circ} \mathrm{C}$ & $14 \mathrm{~h}$ \\
\hline
\end{tabular}




\section{In situ Day 3:}

- Recover the antibody!

\begin{tabular}{|c|c|c|c|}
\hline Step & Description & Temp. & Time \\
\hline 1 & Wash with PBT with slow agitation, dark & RT & $2 \times 5 \min$ \\
\hline 2 & Wash with PBT with slow agitation, dark & RT & $8 \times 20 \mathrm{~min}$ \\
\hline 3 & Wash with NTMT buffer & $\mathrm{RT}$ & $3 \times 5 \min$ \\
\hline 5 & Transfer embryos to a 24 well plate & & \\
\hline 6 & $\begin{array}{l}\text { Staining reaction: add } 500 \mu \mathrm{L} \text { of BCIP/NBT mix } \\
\text { Staining at } 4{ }^{\circ} \text { C overnight is also possible. }\end{array}$ & $37^{\circ} \mathrm{C}$ & \\
\hline 7 & $\begin{array}{l}\text { Stop the reaction: removing of the staining solution and wash in } \\
\text { Stop-Solution }\end{array}$ & RT & $3 \times 1 \min$ \\
\hline 8 & $\begin{array}{l}\text { Removal of the first antibody: add } 0,1 \mathrm{M} \text { Glycin/HCl, } \mathrm{pH} 2.2+ \\
0.1 \% \text { Tween } 20, \text { shake well }\end{array}$ & RT & $2 \times 5 \min$ \\
\hline 9 & Wash with PBT with slow agitation, dark & $\mathrm{RT}$ & $4 \times 5 \mathrm{~min}$ \\
\hline 10 & $\begin{array}{l}\text { Clearing (optional): incubate embryos in } 100 \% \mathrm{EtOH} \text { with slow } \\
\text { agitation } \\
\text { This step cannot be performed after the red staining reaction. (The } \\
\text { red stain dissolves in ETOH very fast.) }\end{array}$ & RT & $2 \times 10 \mathrm{~min}$ \\
\hline 11 & $75 \% \mathrm{EtOH} / 25 \% \mathrm{PBT}$ & RT & $5 \mathrm{~min}$ \\
\hline 12 & $50 \% \mathrm{EtOH} / 50 \% \mathrm{PBT}$ & RT & $5 \mathrm{~min}$ \\
\hline 13 & $25 \% \mathrm{EtOH} / 75 \% \mathrm{PBT}$ & RT & $5 \mathrm{~min}$ \\
\hline 14 & PBT & RT & $4 \times 5 \mathrm{~min}$ \\
\hline 15 & $\begin{array}{l}\text { Antibody-incubation II: Incubate in } 100-200 \mu \mathrm{L} \text { antibody solution. } \\
\text { No additional blocking step is required prior to the second antibody } \\
\text { incubation. } \\
\text { Antiserum pre-absorbed against embryos, } 1: 2000-1: 4000 \text { in } P B T+ \\
2 \mathrm{mg} / \mathrm{mL} \mathrm{BSA} \mathrm{(optional:}+2 \% \text { sheep serum). For storage at } 4^{\circ} \mathrm{C} \text { : } \\
\text { add Sodium Azide to } 0,02 \%\end{array}$ & $4^{\circ} \mathrm{C}$ & $14 \mathrm{~h}$ \\
\hline
\end{tabular}


Solutions:

NTMT staining buffer for $20 \mathrm{~mL}$

- $2 \mathrm{~mL}$ Tris $\mathrm{HCl} \mathrm{pH} \mathrm{9.5,} 1 \mathrm{M}$

- $1 \mathrm{~mL} \mathrm{MgCl}_{2}, 1 \mathrm{M}$

$-2 \mathrm{~mL} \mathrm{NaCl}, 1 \mathrm{M}$

- $200 \mu \mathrm{L} \mathrm{10 \%} \mathrm{Tween} 20$

- add $14.8 \mathrm{~mL} \mathrm{H}_{2} \mathrm{O}$

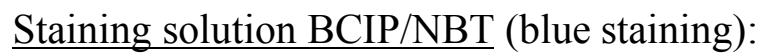

- $4.5 \mu \mathrm{L}$ NBT (Nitro Blue Tetrazolium, Sigma; $75 \mathrm{mg} / \mathrm{mL}$ in 70\% DMF / 30\% $\left.\mathrm{H}_{2} \mathrm{O}\right)$

- 3,5 $\mu \mathrm{L}$ X-phosphate (=BCIP) $(50 \mathrm{mg} / \mathrm{mL}$ in $100 \% \mathrm{DMF})$

- $1 \mathrm{~mL}$ NTMT buffer

$\underline{\text { Stop-Solution }}$

- 0.05M phosphate buffer $\mathrm{pH} 5.8$

- 1mM EDTA

$-0.1 \%$ Tween 20

for $200 \mathrm{~mL}: \quad 92 \mathrm{~mL} 0.1 \mathrm{M} \mathrm{NaH} 2 \mathrm{PO} 4$

$8 \mathrm{~mL} 0.1 \mathrm{M} \mathrm{Na} 2 \mathrm{HPO} 4$

(this mixture should produce a pH of 5.8)

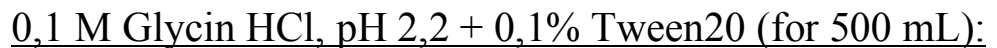

- 3,75 g Glycin

- add $\mathrm{H}_{2} \mathrm{O}$ to $400 \mathrm{~mL}$

- adjust to $\mathrm{pH} 2,2$

- fill to $500 \mathrm{~mL}$ with $\mathrm{H}_{2} \mathrm{O}$

- add $5 \mathrm{ml} \mathrm{10 \%} \mathrm{Tween20}$ 


\section{In situ Day 4:}

- Recover the antibody!

\begin{tabular}{l|l|l|l}
\hline Step & Description & Temp. & Time \\
\hline 1 & Wash with PBT with slow agitation, dark & RT & $2 \times 5$ min \\
\hline 2 & Wash with PBT with slow agitation, dark & RT & $8 \times 20$ min \\
\hline 3 & Wash with NTMT buffer & RT & $3 \times 5$ min \\
\hline 5 & Transfer embryos to a 24 well plate & & \\
\hline 6 & $\begin{array}{l}\text { Staining reaction: add } 500 \mu \text { L of BCIP/INT mix } \\
\text { Staining at } 4^{\circ} \text { C overnight is also possible. }\end{array}$ & $37^{\circ} \mathrm{C}$ & \\
\hline 7 & $\begin{array}{l}\text { Stop the reaction: removing of the staining solution and wash in } \\
\text { Stop-Solution }\end{array}$ & RT & $3 \times 1$ min \\
\hline 8 & $\begin{array}{l}\text { Transfer embryos to 6-well plates in } 80 \% \text { Glycerol - 20\% Stop- } \\
\text { Solution. }\end{array}$ & RT & \\
\hline
\end{tabular}

Solutions:

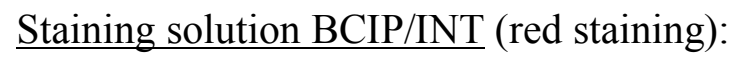

- 3,5 $\mu \mathrm{L}$ INT (Iodonitrotetrazolium violet, Sigma; $50 \mathrm{mg} / \mathrm{mL}$ in DMSO)

- 3,5 $\mu \mathrm{L}$ X-phosphate (=BCIP) $(50 \mathrm{mg} / \mathrm{mL}$ in $100 \% \mathrm{DMF})$

- 1 mL NTMT buffer

Preabsorption of the antibody:

\section{Method 1:}

- harvest hundreds of embryos, at different stages.

- fix overnight in 4\% PFA in PBS.

- transfer to $\mathrm{MeOH}, 4-5$ changes. Store embryos at $-20^{\circ} \mathrm{C}$.

- for preabsorbtion, take about 200 embryos (for ca. $20 \mathrm{ml}$ of final 1:2000 antibody solution).

- wash embryos 2x in PBT and dechorionate by hand

- wash another 5x in PBT 
- spin the concentrated antibody $5 \mathrm{~min}$. at $13000 \mathrm{rpm}$

- incubate antibody (dilution 1:400) on the embryos in BSA, $2 \mathrm{mg} / \mathrm{ml}$ in PBT Shake at room temp. for at least $1 \mathrm{~h}$. (The embryos can also be smashed prior to incubation. Spin down after incubation and carefully transfer the supernatant to a separate tube before diluting to the final concentration).

- Sterile filter using a 0,2-0,45 $\mu \mathrm{m}$ Cellulose Acetate filter. Best is dilute the antibody to 1:2000 prior to filtering.

- final antibody solution:

1:2000 - 1:4000 in PBT, (optional: $+2 \%$ sheep serum), $+2 \mathrm{mg} / \mathrm{ml}$ BSA

- keep the antibody at this concentration at $4{ }^{\circ} \mathrm{C}$. For storage, add Sodium Azide to $0,02 \%$

\section{Method 2:}

- process 50 embryos along with the others (same age) through all the first steps of in situ hybridization except that no probe is used for hybridization of these embryos.

during blocking of the other samples:

- block the embryos for preabsorption only $10 \mathrm{~min}$

- spin the concentrated antibody $5 \mathrm{~min}$. at $13000 \mathrm{rpm}$

- incubate antibody at a dilution of 1:400 on the embryos in BSA, $2 \mathrm{mg} / \mathrm{ml}$ in PBT at RT for a few hours

- remove antibody solution from the embryos, dilute to final concentration (as above, no sterile filtration required)

\section{Prepare the anti $X-A P$ antibody:}

- make 1:200 dilution of the Ab in blocking solution and pre-adsorb it against fixed MeOH-zebrafish embryos at different stages (primarily 24hrs) over night at $4^{\circ} \mathrm{C}$ on a wheel. (the embryos have to be treated the way those in a real in situ are treated i.e, Prot.K, further fix and blocking)

- fixed embryos should comprise approximately $10 \%$ of the total volume

- use pre-adsorbed $\mathrm{Ab}$ at 500 - 5000 dilution (try 1:2000 to begin with) 


\subsubsection{Immunohistochemistry of whole mount zebrafish embryos}

\section{Immunohistochemistry protocol:}

\begin{tabular}{|c|c|c|c|}
\hline Step & Description & Temp. & Time \\
\hline 1 & $\begin{array}{l}\text { Fixation of embryos: Remove chorion with forceps before fixation. } \\
\text { Embryos were transferred in pre-warmed (RT) PFA (4\%) in PBS. }\end{array}$ & RT & $2-3 \mathrm{~h}$ \\
\hline 2 & Wash with PBTX (pre-cooled at $4^{\circ} \mathrm{C}$ ) & $4^{\circ} \mathrm{C}$ & $6 \times 10 \mathrm{~min}$ \\
\hline 3 & Wash with PBTB & $4^{\circ} \mathrm{C}$ & $2 \times 30 \mathrm{~min}$ \\
\hline 4 & Blocking: PBTB & $4^{\circ} \mathrm{C}$ & $12 \mathrm{~h}$ \\
\hline 5 & $\begin{array}{l}\text { Primary antibody: dilute antibody in } 1 \mathrm{~mL} \text { PBTB, Combination of } \\
\text { several primary antibodies during the incubation step possible. } \\
\text { Dilution depends on antibody. } \\
\text { slow agitation and keep dark }\end{array}$ & $4^{\circ} \mathrm{C}$ & $2-3$ days \\
\hline 6 & Recover the antibody. & & \\
\hline 7 & Wash with PBTX, slow agitation and keep dark & $4^{\circ} \mathrm{C}$ & $8 \times 1 h$ \\
\hline 8 & Wash with PBTX, slow agitation and keep dark & $4^{\circ} \mathrm{C}$ & $\mathrm{o} / \mathrm{n}$ \\
\hline 9 & $\begin{array}{l}\text { Secondary antibody: dilute antibody in } 1 \mathrm{~mL} \text { PBTB, Combination } \\
\text { of several secondary antibodies during the incubation step possible. } \\
\text { Dilution depends on antibody. } \\
\text { slow agitation and keep dark }\end{array}$ & $4^{\circ} \mathrm{C}$ & $\mathrm{o} / \mathrm{n}$ \\
\hline 10 & Recover the antibody. & & \\
\hline 11 & Wash with PBTX, slow agitation and keep dark & $4^{\circ} \mathrm{C}$ & $8 \times 1 h$ \\
\hline 12 & Wash with PBTX, slow agitation and keep dark & $4^{\circ} \mathrm{C}$ & $\mathrm{o} / \mathrm{n}$ \\
\hline 13 & Store embryos in PBTX & $4^{\circ} \mathrm{C}$ & \\
\hline
\end{tabular}

Solutions:

\section{$\underline{\text { PBTX }}$}

- PBS (see 6.11.5 First Day of in situ)

- add $0,2 \%$ Triton $\mathrm{X}-100$

\section{$\underline{\text { PBTB }}$}

$$
\begin{aligned}
& \text { - PBTX } \\
& \text { - add 1\% BSA }
\end{aligned}
$$




\subsubsection{Fluorescent live imaging}

\section{Stereomicroscopy:}

Images were obtained using a Zeiss Axioplan2 microscope controlled by the Metamorph software (Universal Imaging). Low magnification time-lapse movies were generated using a 10x objective at a rate of one frame per minute. High magnification time-lapse movies were generated using a $63 \mathrm{x}$ or $40 \mathrm{x}$ objective capturing frames at 2-, 4-, 5- and 10-second intervals. Speed measurements of migrating PGCs and colour-alignments were performed using the Metamorph software (Universal Imaging).

\section{Confocal-Microscopy:}

Images were obtained using a Leica TCS Confocal microscope controlled by the internal Leica software. High magnification time-lapse movies were generated using a $63 \mathrm{x}$ or $40 \mathrm{x}$ objective capturing frames at $0.8-, 1.6-$ and 10 -second intervals. Pictures were recorded in the xyzt modus (allows z-stacks as well as recordings over time) with $512 \times 512$ or $1024 \times 1024$ pixel resolution. The laser intensity, potentiometer, gain and offset were adjusted according to the individual conditions of the experiments (fluorescent intensity based on the probe characteristics). The recorded frames of migrating germ cells were processed using the Quantity-Mode (Stack profile/Statistics) of the TCS SL confocal software provided by Leica.

\section{$\underline{6.11 .7 \quad \text { Data processing and analysis }}$}

In situ pictures were taken by using the Zeiss Axioplan 2 microscope controlled by the Metamorph software (Universal Imaging). Time-lapse analysis (tracking of objects, speed-measurements) was performed by the Metamorph software. The stacks from the FRET-data were analysed by using the ImageJ software. Any documentation and modifications of in situ pictures and time-lapse snapshots was done with Adobe Photoshop 8.0. Statistical documentation of data was carried out by using the Microsoft Excel program. 


\subsection{Detailed description of adapted experiments performed for this work}

6.12.1 Identification of the askopos (kop) gene

The kop cDNA (Gen Bank accession no. AY572416) was identified in a large-scale screen for genes expressed in a tissue-specific manner during early zebrafish development (Thisse et al., 2001). 3'- and 5'-RACE analysis confirmed that the original cDNA clone represents the full-length mRNA.

\subsubsection{Alteration of Kop activity by RNA injections}

Capped sense RNAs were synthesized using the Message Machine Kit (Ambion) and injected according to standard procedures.

The pSP64-kop-globin-3'UTR construct contains the kop open reading frame (ORF) cDNA cloned into the pSP64TS vector, which includes the untranslated regions of the Xenopus globin gene. Injected RNA synthesized from this construct is inherited and translated by all cells of the embryo.

The pSP64-kop-nos1-3'UTR construct contains the kop open reading frame cloned upstream of the nanos 1 3'UTR. Injected RNA produced from this construct is translated and stabilized specifically in the PGCs.

Site-directed mutagenesis was performed by PCR using the original kop clone (cg 1111) as a template to obtain the pSP64-DNkop-globin-3'UTR construct. Two nucleotide mismatches were introduced leading to the exchange of Gly280 with Ser280 in the ATP/GTP-binding site motif A (P-loop; ANLTSGKT) of Kop. Injected RNA synthesized from this construct is expressed in a similar pattern to that of pSP64-kop-globin-3'UTR RNA (data not shown). 


\subsubsection{Kop subcellular localization and kop morpholino activity}

The pSP64-kop-gfp-nos1-3'UTR construct includes the fusion of kop and GFP ORFs upstream of the 3'UTR of nanos 1 .

The kop morpholino (5'-GAATGGATGTATCTGTGAATGACAT-3') and the standard control morpholino were produced by GeneTools, OR.

For the knockdown experiments: 0.6 pmol - 5.4 pmol of these morpholino antisense oligonucleotides dissolved in $10 \mathrm{mM}$ HEPES ( $\mathrm{pH}$ 7.6) were injected into 1-cell stage wild-type embryos. To examine the specific function of the kop morpholino, DsRedex-nos1-3'UTR and kop-gfp-nos1-3'UTR (each 300 pg RNA) was co-injected with 0.6 pmol of kop morpholino.

\section{$\underline{6.12 .4 \quad k o p \text { promoter cloning }}$}

RZPD Zebrafish genomic PAC-library 706 was screened for kop clones. Positive clones were identified and PAC clone BUSMP706O19135Q2 was used to clone a 4.9 $\mathrm{kbp}$ region upstream of the first exon of kop.

\section{$\underline{6.12 .5}$ Cloning of kop-EGFP-F-nos1-3'UTR construct and generation of transgenic fish}

The kop-EGFP-F-nos1-3'UTR promoter construct was generated by PCR amplification of the kop promoter region using the forward primer (GAGCTCGCCACTGCATCATCCATTC) and the reverse primer (GACTAGTCCGAATGATATTTTTGTAG). The promoter region was cloned upstream of EGFP containing the farnesylation sequence (EGFP-F) and the 3'UTR of nanos1. This construct was introduced into the I-SceI-pBSII-SK+ vector and the purified plasmid DNA was injected into 1-cell stage fish embryos as previously described in (Thermes et al., 2002). A female fish carrying the transgene was identified by screening for GFP expressing PGCs among the progeny of injected females. 


\subsubsection{Constructs for RNA expression, knockdown and drug experiments}

Capped sense RNAs were synthesized using the Message Machine Kit (Ambion) and injected according to standard procedures.

The pSP64-gfp-nos1-3'UTR (210 pg) and the pSP64-E-cadherin1-nos1-3'UTR (90 $\mathrm{pg}$ ) constructs contains the $g f p$ or the full-length zebrafish E-cadherin 1 open reading frame (ORF) respectively followed by the 3' untranslated regions of the nanos 1 gene. The RNAs produced from these constructs are translated and stabilized preferentially in the PGCs.

Dead end morpholinos ( $d n d-\mathrm{MO}, 1200 \mathrm{pg}$ ) were injected as described in (Weidinger et al., 2003).

The transcription inhibitor $\alpha$-amanitin (Sigma) was injected into 1-cell stage embryos as previously described in (Kane et al., 1996).

\subsubsection{Fluorescence Microscopy and Imaging of live cells}

Images were obtained using a Zeiss Axioplan2 microscope controlled by the Metamorph software (Universal Imaging). Low magnification time-lapse movies were generated using a 10x objective at a rate of one frame per minute. High magnification time-lapse movies were generated using a $63 \mathrm{x}$ or $40 \mathrm{x}$ objective capturing frames at 10-second intervals. For time-lapse analysis, kop-EGFP-F-nos 13'UTR transgenic females were crossed to wild-type males.

For the E-cadherin forced expression experiments, $g f p$-nos1-3'UTR RNA was injected into 1-cell stage wild-type embryos to label PGCs.

Speed measurements of migrating PGCs were performed using the Metamorph software (Universal Imaging). 


\subsubsection{Cell Transplantation}

\section{Attraction Assay:}

Wild-type 1-cell stage donor embryos were injected with 240 pg sdf-1a-globin3'UTR RNA (morpholino resistant $s d f-1 a$; (Doitsidou et al., 2002)), $s d f-1 a$ and $s d f-1 b$ morpholino (0.4 pmol each) and dextran Alexa Fluor 568 (10,000 Da; Molecular Probes, $0.15 \mathrm{ng}$ ). Progeny of kop-EGFP-F-nos 1-3'UTR transgenic females injected at the 1-cell stage with $s d f-1 a$ and $s d f-1 b$ morpholino ( 0.4 pmol each) served as hosts. In transplantation experiments, cells from $5.3 \mathrm{hpf}$ donor embryos were transferred into 3 hpf and $5.3 \mathrm{hpf}$ host embryos.

\section{Heterochronic PGC transplantations:}

1-cell stage embryos were injected with DsRedex1-globin-3'UTR (300 pg) and $g f p$ nos 1-3'UTR (240 pg) RNA served as donors from which PGCs were isolated at 12 hpf. mGFP labeled PGCs were transplanted into 3 hpf wild-type or $\alpha$-amanitin injected host embryos. Lack of cells expressing only DsRed served as an indication that no somatic cells were co-transplanted with the PGCs. Conversely, progeny of kop-EGFP-F-nos 1-3'UTR transgenic females injected with $\alpha$-amanitin at the 1-cell stage served as donors from which PGCs were isolated at $7 \mathrm{hpf}$ and transplanted into 5.3 hpf egfp-f-globin-3'UTR (6 pg, to observe membranes of somatic cells) injected wild-type host embryos.

\subsubsection{Immunohistochemistry of E-cadherin}

Embryos were fixed with 4\% paraformaldehyde/PBS for 2 hours at room temperature. After fixation, the embryos were washed three times for 5 min with PBTX (PBT, $0.2 \%$ TritonX-100) and subsequently blocked with PBTB (PBT, 0.2\% TritonX-100, $1 \%$ BSA) for 1 hour. The embryos were incubated in the blocking solution containing the primary antibody overnight at $4{ }^{\circ} \mathrm{C}$. GFP antibody was obtained from Santa Cruz Biotechnology and anti human E-cadherin antibody from Transduction Laboratories. The embryos were then washed with PBTX 8 times for at least 30 minutes each. Thereafter, they were incubated with the secondary antibody (1:200 Cy2-conjugated 
anti-rabbit polyclonal, Jackson ImmunoResearch Laboratories; 1:200 Alexa Fluor546-conjugated anti-mouse IgG, Molecular Probes) overnight at $4^{\circ} \mathrm{C}$. Finally, embryos were washed with PBTX for several hours and observed by confocal microscopy (Leica TCS SL).

\section{$\underline{6.12 .10}$ in vivo staining of activated caspases}

Embryos were grown at $28^{\circ} \mathrm{C}$ in $0.3 \mathrm{X}$ Danieau's solution. After removal of the chorion, the embryos were incubated in $300 \mu \mathrm{L}$ of $0.3 \mathrm{X}$ Danieau's solution plus $1 \mu \mathrm{L}$ of Red-VAD-FMK (sulf-rhodamine conjugated VAD-FMK caspase family inhibitors, BIOCAT) for 1 hour at $30^{\circ} \mathrm{C}$. The embryos were then washed with Wash Buffer (BIOCAT) for at least 5 minutes under slow agitation. The embryos were then mounted and observed under a Zeiss Axioplan2 fluorescence microscope controlled by Metamorph software (Universal Imaging). Caspase positive cells show bright red signal, whereas negative cells show weak background signal.

The diphtheria toxin A-chain open reading frame (ORF) cDNA was cloned into the pSP64 vector. RNA synthesized from this construct was co-injected with Oregon Green 488 (Dextran 70’000 Da, Molecular Probes) into one of 64 blastomeres (2 hpf) of wild-type embryos (0,15 pg diphtheria toxin RNA, 6,3 ng Oregon Green 488).

The transcription inhibitor $\alpha$-amanitin (Sigma) was injected into 1-cell stage embryos as previously described (Kane et al., 1996).

Dead end morpholinos ( $d n d-\mathrm{MO}, 1200 \mathrm{pg}$ ) were injected as described in (Weidinger et al., 2003).

For the $\alpha$-amanitin or $d n d-\mathrm{MO}$ injection, kop-EGFP-F-nos1-3'UTR transgenic females were crossed to wild-type males to obtain embryos whose PGCs were labelled with GFP. 


\subsubsection{Confocal-Data analysis}

Green channel (PGC membrane) and red channel (E-cadherin) pictures, recorded on a Leica TCS SL confocal microscope were analyzed by using the Metamorph software (Universal Imaging) (see Fig. 3-6B).

\subsubsection{Whole-mount in situ hybridization}

One- and two-colour whole-mount in situ hybridization was performed as described previously (Jowett and Lettice, 1994) with modifications according to (Hauptmann and Gerster, 1994) and (Weidinger et al., 2002). The following Digoxigenin-labeled probes were used: mlck, stim-1, dapk, nanos 1 (Köprunner et al., 2001) and sdf-1a (Doitsidou et al., 2002).

\subsubsection{Constructs for RNA expression to label PGCs}

All capped sense RNAs were synthesized by using the Message Machine Kit (Ambion) and injected into the one-cell stage according to standard procedures. The following constructs were used to label the germ cells thus all genes are fused to the 3' untranslated regions (3'UTR) of the nanos-1 gene which allows the RNA to be translated and stabilized specifically in the PGCs.

The pSP64-gfp-nos1-3'UTR (210 pg) construct contains the full-length open reading frame (ORF) of $g f p$ which is localized to the cytoplasm of PGCs.

The pSP64-egfp-f-nos1-3'UTR (210 pg) and pSP64-DsRedex1-f-nos1-3'UTR (300 pg) constructs contain the full-length ORFs of egfp and DsRedexl respectively in addition are linked to a farnesylation signal sequence that is used for labelling the membrane of germ cells. 


\subsubsection{Alteration of Mlck and Dapk activity by RNA injections}

The following constructs were used to force express constitutively activated or dominant negative forms of the mouse myosin light chain kinase (MLCK) or the mouse death associated protein kinase (DAPK) to interfere with the germ cell intrinsic level of myosin light chain activation consequently changing the level of myosin contraction. The different forms of MLCK and DAPK are fused to 3'UTR of the nanos-1 gene, which allows the RNA to be translated and stabilized specifically in the PGCs. The following constructs have been used: pSP64-wt-mlck-nos1-3'UTR (wild-type form (900 pg), 1 - 1949aa), TOPO4-CA-mlck-nos1-3'UTR (active form (900 pg), 1 - 1775aa) was created according to previously published data about a mutant human MLCK missing the auto-inhibitory domain and the calmodulin-binding site (Wadgaonkar et al., 2003), TOPO4-DN-mlck-nos1-3'UTR (dominant negative form (1200 pg) $\Delta 1611-1637 \mathrm{aa}$ ) was created according to previously published data about a mutant human MLCK lacking the ATP-binding site (Wadgaonkar et al., 2003), pSP64-CA-DAPK-nos1-3'UTR (activated form (450 pg) and pSP64-DNDAPK-nos 1-3'UTR (dominant negative form (450 pg) (Shohat et al., 2002)).

\subsubsection{MLCK subcellular localization}

The pSP64-mlck-fip-nos1-3'UTR construct includes a mlck-FRET-reporter which consists of the $\mathrm{MLCK}_{125}$ isoform fused to GFP linked to BFP via the $\left[\mathrm{Ca}^{2+}\right]_{4} /$ calmodulin binding domain (Chew et al., 2002) upstream of the 3'UTR of nanos1. This construct was not used to measure the activity of MLCK in PGCs however it served to display MLCK localization in the germ cell during migration. mlck-fip-nos1-3'UTR (300 pg) was co-injected with pSP64-DsRedex1-f-nos1-3'UTR (300 pg) sense RNA into the one-cell stage embryo to observe MLCK localization in PGCs at 9 hpf. 


\subsubsection{Myosin light chain phosphorylation measurements}

The following constructs were used to detect spacial and temporal activity of the myosin light chain in migrating PGCs. Both, the pSP64-CRCit-nos1-3'UTR and the pSP64-mCRCitAA-nos1-3'UTR construct includes a mlc-FRET reporter (Yamada et al., 2005) which is fused to 3'UTR of the nanos-1 gene, which allows the RNA to be translated and stabilized specifically in the PGCs.

The pSP64-CRCit-nos1-3'UTR construct consists of CFP fused to mlc and Citrine (Yamada et al., 2005) upstream of the 3'UTR of nanos1. The pSP64-mCRCitAAnos 1-3'UTR construct is the mutated form of CRCit which cannot be phosphorylated anymore. This $m C R C i t A A$ construct served as the control for the CRCit-FRET measurements.

FRET-Images were obtained using a Zeiss Axioplan2 microscope controlled by the Metamorph software (Universal Imaging). High magnification time-lapse movies were generated using a 40x objective (Achroplan, Zeiss) capturing frames at 20second intervals with the $\mathrm{RT}_{\mathrm{SE}}$ camera device (Diagnostic Instruments Inc.). The FRET-response was recorded by exciting at $430 \mathrm{~nm}$ and subsequently capturing pairs of images at two emission wavelengths (480 nm (CFP) and $535 \mathrm{~nm}$ (YFP)) simultaneously. The activation level of the FRET-reporter thus the phosphorylation level of $m l c$ was analysed and quantified on the basis of the intensity-ratio of $\mathrm{F}_{535} / \mathrm{F}_{480}$ using the ImageJ software.

\section{$\underline{6.12 .17 \quad \text { Measurement of calcium levels in PGCs }}$}

The free calcium indicator Oregon Green 488 BAPTA-1 (500 $\mu \mathrm{M}$, Dextran, 10000 MW, Molecular Probes O-6798) and vasa-DsRedex1-nos1-3'UTR sense RNA (180 pg) was co-injected into the one-cell stage embryo. The vasa-DsRedex1 labeled the granules of PGCs for identification of the cells since Oregon Green stains all cells in the embryo. At 9 - 12 hpf, migrating PGCs were observed by confocal microscopy using the Leica TCS SL device. The recorded frames of migrating germ cells were processed using the Quantity-Mode (Stack profile/Statistics) of the TCS SL confocal software provided by Leica. The free calcium distribution and levels in the PGCs was analyzed and quantified by calculating fluorescent intensity ratios of $F_{\text {front }} / F_{\text {nucleus/2 }}$ 
(mean fluorescent intensity of selected area in leading edge versus nucleus). The signal intensity of the nucleus was taken as an internal standard to compare PGCs among different experiments and developmental stages.

\subsubsection{Alteration of Calcium by RNA and morpholino injections}

The $c x c r 4 b, s d f-1$ a morpholinos as well as the standard control morpholino were produced by GeneTools, OR. The knockdown experiments by $C x c r 4 b$ and $s d f-1 \mathrm{a}$ morpholino antisense oligo nucleotide injection $(0.4 \mathrm{pmol})$ were performed as described previously (Doitsidou et al., 2002).

The following constructs were used to force express proteins containing $\mathrm{Ca}^{2+}$-binding sites that are known to 'buffer' calcium (e.g. EF-hand) to interfere with endogenous levels of calcium in the germ cells. Zebrafish parvalbumin (pvalb, prv) and mouse calbindinD28k (calbp28, clb28) are fused to a farnesylation signal sequence and additionally to 3'UTR of the nanos-1 gene, which allows the RNA to be translated and stabilized specifically in the PGCs. The following constructs have been used: pSP64-pvlb-f-nos1-3'UTR (wild-type form, 900 pg), pSP64-mutpvlb-f-nos1-3'UTR (mutated form with non-functional $\mathrm{Ca}^{2+}$-binding sites, $900 \mathrm{pg}$ ) was created according to previously published data about a mutant human alpha-parvalbumin disabled to bind $\mathrm{Ca}^{2+}$ (Rhyner et al., 1996), pSP64-calbD28K-f-nos1-3'UTR (wild-type form, 900 $\mathrm{pg})$.

STIM1, a protein involved in the $\mathrm{Ca}^{2+}$-store depleted-mediated calcium influx (Liou et al., 2005) was used to interfere with the endogenous calcium levels in migrating PGCs by expressing a mutant form of STIM1. The pSP64-stim1-DsRedex1-nos13'UTR (wild-type form, $300 \mathrm{pg}$ ) was used to confirm the cellular localization (Liou et al., 2005) and served as a control for the pSP64-mutstim1-DsRedex1-nos1-3'UTR (mutated form, $300 \mathrm{pg}$ ) over expression experiment. 


\subsubsection{Fluorescence Stereo-Microscopy and Confocal Imaging of live cells}

Images were obtained using the Axioplan2 stereo-microscope (Zeiss) controlled by the Metamorph software (Universal Imaging). High magnification time-lapse movies were generated using either a $63 \mathrm{x}$ - or $40 \mathrm{x}$-objective capturing frames at 2-, 4-, or $10-$ second intervals depending on the time-resolution needed. Low magnification timelapse movies were generated using a 10x-objective at a rate of one frame per minute. For time-lapse analysis, egfp-f-nos1-3'UTR sense RNA was injected into one-cell stage wild-type embryos to label the plasma membrane of PGCs.

Speed measurements and tracking of migrating germ cells were performed using the Track Objects application of the Metamorph software.

Confocal images were acquired by using the Leica TCS SL confocal system. High magnification time-lapse movies of PGCs containing Oregon Green and expressing vasa-DsRedex 1 were generated using a $63 \mathrm{x}$-objective, capturing frames at 0.8 -second intervals at $490 \mathrm{~nm}$ excitation wavelength.

High-magnification images of stim1-DsRedex1 localization in PGCs were taken using a $63 \mathrm{x}$-objective at $558 \mathrm{~nm}$ excitation wavelength. The recorded frames of migrating germ cells were processed using the Quantity-Mode (Stack profile/Statistics) of the TCS SL confocal software provided by Leica. 


\section{$7 \quad$ List of Figures}

Fig. 2-1: $\quad$ Discrete steps in Drosophila germ cell migration.

Page 8

Fig. 2-2: $\quad$ PGC migration in the chick embryo.

Page 9

Fig. 2-3: $\quad$ Embryonic mouse development and germ cell migration.

Page 11

Fig. 2-4: $\quad$ Specification and migration of zebrafish PGCs.

Page 12

Fig. 2-5: $\quad$ Expression pattern of CXCR4b and SDF-1a and alteration of SDF-1a signalling.

Page 14

Fig. 3-1: $\quad$ kop RNA is expressed in the germ plasm and the encoded protein is localized to the nucleus.

Page 16

Fig. 3-2: $\quad$ Early labelling of PGCs in live embryos.

Page 19

Fig. 3-3: $\quad$ Marked alterations in migratory behaviour are detectable during earliest stages of PGC development.

Page 22

Fig. 3-4: $\quad$ Zygotically transcribed genes are essential for PGC polarization and motility.

Page 25

Fig. 3-5: $\quad$ PGCs do not activate caspases before undergoing cell death and PGCs lacking Dead end function die during somitogenesis stages. $\quad$ Page 27

Fig. 3-6: $\quad$ E-cadherin is dynamically regulated during early stages $\begin{array}{ll}\text { of PGC development. } & \text { Page } 30\end{array}$

Fig. 3-7: The progression of PGC responsiveness to SDF-1a.

Fig. 3-8: $\quad$ Reduced Calcium levels in the front of migratory PGCs lacking CXCR4b.

Fig. 3-9: $\quad$ Calcium buffering in PGCs leads to aberrant migratory behaviour.

Fig. 3-10: Zebrafish stim1 RNA expression pattern.

Fig. 3-11: $\quad$ Mutated STIM1 increases protrusive activity of PGCs and interferes with their normal migration behaviour.

Fig. 3-12: $\quad$ MLCK at the leading edge mediates MLC activation upon phosphorylation.

Fig. 3-13: $\quad$ Zebrafish $m l c k$ and $d a p k$ RNA expression pattern.

Fig. 3-14: $\quad$ Alterations in MLC kinase activity leads to aberrant PGC morphology and migration behaviour.

Fig. 4-1: $\quad$ Differentiation stages during early PGC development leading to motility, polarization and guided migration.

Fig. 4-2: $\quad$ Myosin contraction needed for the formation of protrusions in migrating PGCs. 


\section{References}

Affolter, M. and Weijer, C. J. (2005). Signaling to cytoskeletal dynamics during chemotaxis. Dev Cell 9, 19-34.

Anderson, R., Fassler, R., Georges-Labouesse, E., Hynes, RO., Bader, BL., Kreidberg, JA., Schaible, K., Heasman, J., Wylie, C. (1999). Mouse primordial germ cells lacking beta1 integrins enter the germline but fail to migrate normally to the gonads. Development 126, 1655-1664.

Ara, T., Nakamura, Y., Egawa, T., Sugiyama, T., Abe, K., Kishimoto, T., Matsui, Y. and Nagasawa, T. (2003). Impaired colonization of the gonads by primordial germ cells in mice lacking a chemokine, stromal cell-derived factor-1 (SDF-1). Proc Natl Acad Sci U S A 100, 5319-23.

Arakawa, Y., Bito, H., Furuyashiki, T., Tsuji, T., Takemoto-Kimura, S., Kimura, K., Nozaki, K., Hashimoto, N., Narumiya, S. (2003). Control of axon elongation via an SDF-1alpha/Rho/mDia pathway in cultured cerebellar granule neurons. J Cell Biol 161(2). 381-91.

Balkwill, F. (2004). Cancer and the chemokine network. Nat Rev Cancer 4, 540-50.

Beccari, S., Teixeira, L. and Rørth, P. (2002). The JAK/STAT pathway is required for border cell migration during Drosophila oogenesis. Mechanisms of Development 111, 115-23.

Bendel-Stenzel, M., Anderson, R., Heasman, J. and Wylie, C. (1998). The origin and migration of primordial germ cells in the mouse [In Process Citation]. Semin Cell Dev Biol 9, 393-400.

Bendel-Stenzel, M. R., Gomperts, M., Anderson, R., Heasman, J. and Wylie, C. (2000). The role of cadherins during primordial germ cell migration and early gonad formation in the mouse. Mechanisms of Development 91, 143-52.

Bernex, F., De Sepulveda, P., Kress, C., Elbaz, C., Delouis, C. and Panthier, J. J. (1996). Spatial and temporal patterns of c-kit-expressing cells in WlacZ/+ and WlacZ/WlacZ mouse embryos. Development 122, 3023-33.

Blaser, H., Eisenbeiss, S., Neumann, M., Reichman-Fried, M., Thisse, B., Thisse, C. and Raz, E. (2005). Transition from non-motile behaviour to directed migration during early PGC development in zebrafish. Journal of Cell Science 118, 4027-38.

Braat, A., Zandbergen, T., van de Water, S., Goos, H. and Zivkovic, D. (1999). Characterization of zebrafish primordial germ cells: morphology and early distribution of vasa RNA. Developmental Dynamics 216, 153-67.

Brown, J. and Bridgman, P. C. (2003). Role of myosin II in axon outgrowth. Journal of Histochemistry and Cytochemistry 51, 421-8.

Brown, M. E. and Bridgman, P. C. (2004). Myosin function in nervous and sensory systems. Journal of Neurobiology 58, 118-30. 
Carragher, N. O. and Frame, M. C. (2002). Calpain: a role in cell transformation and migration. International Journal of Biochemistry and Cell Biology 34, 1539-43.

Chalasani, S. H., Sabelko, K. A., Sunshine, M. J., Littman, D. R. and Raper, J. A. (2003). A chemokine, SDF-1, reduces the effectiveness of multiple axonal repellents and is required for normal axon pathfinding. Journal of Neuroscience 23, 1360-71.

Chard, P. S., Bleakman, D., Christakos, S., Fullmer, C. S. and Miller, R. J. (1993). Calcium buffering properties of calbindin D28k and parvalbumin in rat sensory neurones. Journal of Physiology 472, 341-57.

Charras, G. T., Yarrow, J. C., Horton, M. A., Mahadevan, L. and Mitchison, T. J. (2005). Non-equilibration of hydrostatic pressure in blebbing cells. Nature 435, 365-9.

Chew, T. L., Wolf, W. A., Gallagher, P. J., Matsumura, F. and Chisholm, R. L. (2002). A fluorescent resonant energy transfer-based biosensor reveals transient and regional myosin light chain kinase activation in lamella and cleavage furrows. Journal of Cell Biology 156, 543-53.

Chilton, J. K. (2006). Molecular mechanisms of axon guidance. Developmental Biology. (Article in press)

Chong, S., Emelyanov, A., Gong, Z. and Korzh, V. (2001). Expression pattern of two zebrafish genes, cxcr4a and cxcr4b. Mechanisms of Development 109, 347-54.

Christiansen, J. H., Coles, E. G. and Wilkinson, D. G. (2000). Molecular control of neural crest formation, migration and differentiation. Current Opinion in Cell Biology 12, 719-24.

Christofori, G. (2003). Changing neighbours, changing behaviour: cell adhesion molecule-mediated signalling during tumour progression. EMBO Journal 22, 231823.

Cockcroft, S. (1992). G-protein-regulated phospholipases C, D and A2-mediated signalling in neutrophils. Biochimica et Biophysica Acta 1113, 135-60.

De Miguel, M. P., Cheng, L., Holland, E. C., Federspiel, M. J. and Donovan, P. J. (2002). Dissection of the c-Kit signaling pathway in mouse primordial germ cells by retroviral-mediated gene transfer. Proc Natl Acad Sci U S A 99, 10458-63.

Di Carlo, A. and De Felici, M. (2000). A role for E-cadherin in mouse primordial germ cell development. Developmental Biology 226, 209-19.

Doitsidou, M., Reichman-Fried, M., Stebler, J., Koprunner, M., Dorries, J., Meyer, D., Esguerra, C. V., Leung, T. and Raz, E. (2002). Guidance of Primordial Germ Cell Migration by the Chemokine SDF-1. Cell 111, 647-59.

Dormann, D. and Weijer, C. J. (2003). Chemotactic cell movement during development. Current Opinion in Genetics and Development 13, 358-64. 
Dumstrei, K., Mennecke, R. and Raz, E. (2004). Signaling Pathways Controlling Primordial Germ Cell Migration in Zebrafish. Journal of Cell Science 117, 47874795.

Dumstrei, K., Wang, F., Shy, D., Tepass, U. and Hartenstein, V. (2002). Interaction between EGFR signaling and DE-cadherin during nervous system morphogenesis. Development 129, 3983-94.

Eddy, R. J., Pierini, L. M., Matsumura, F. and Maxfield, F. R. (2000). Ca2+dependent myosin II activation is required for uropod retraction during neutrophil migration. Journal of Cell Science 113 (Pt 7), 1287-98.

Fernandis, A. Z., Prasad, A., Band, H., Klosel, R. and Ganju, R. K. (2004). Regulation of CXCR4-mediated chemotaxis and chemoinvasion of breast cancer cells. Oncogene 23, 157-67.

Ganju, R. K., Brubaker, S. A., Meyer, J., Dutt, P., Yang, Y., Qin, S., Newman, W. and Groopman, J. E. (1998). The alpha-chemokine, stromal cell-derived factor1alpha, binds to the transmembrane G-protein-coupled CXCR-4 receptor and activates multiple signal transduction pathways. Journal of Biological Chemistry 273, 23169-75.

Garcia-Castro, M., Anderson, R., Heasman, J. and Wylie, C. (1997). Interactions between germ cells and extracellular matrix glycoproteins during migration and gonad assembly in the mouse embryo. Journal of Cell Biology 138, 471-80.

Gavis, E. R. and Lehmann, R. (1994). Translational regulation of nanos by RNA localization. Nature 369, 315-8.

Ginsburg, M. and Eyal-Giladi, H. (1987). Primordial germ cells of the young chick blastoderm originate from the central zone of the area pellucida irrespective of the embryo-forming process. Development 101, 209-19.

Gomez, T. M. and Zheng, J. Q. (2006). The molecular basis for calcium-dependent axon pathfinding. Nat Rev Neurosci 7, 115-25.

Gomperts, M., Garcia-Castro, M., Wylie, C. and Heasman, J. (1994). Interactions between primordial germ cells play a role in their migration in mouse embryos. Development 120, 135-41.

Goto, T., Adjaye, J., Rodeck, C. H. and Monk, M. (1999). Identification of genes expressed in human primordial germ cells at the time of entry of the female germ line into meiosis. Mol Hum Reprod 5, 851-60.

Gritsman, K., Zhang, J., Cheng, S., Heckscher, E., Talbot, W. S. and Schier, A. F. (1999). The EGF-CFC protein one-eyed pinhead is essential for nodal signaling. Cell 97, 121-32. 
Halloran, M. C. and Berndt, J. D. (2003). Current progress in neural crest cell motility and migration and future prospects for the zebrafish model system. Developmental Dynamics 228, 497-513.

Hashimoto, Y., Maegawa, S., Nagai, T., Yamaha, E., Suzuki, H., Yasuda, K. and Inoue, K. (2004). Localized maternal factors are required for zebrafish germ cell formation. Developmental Biology 268, 152-61.

Hauptmann, G. and Gerster, T. (1994). Two-color whole-mount in situ hybridization to vertebrate and Drosophila embryos. Trends in Genetics 10, 266.

Hay, B., Ackerman, L., Barbel, S., Jan, L. and Jan, Y. (1988). Identification of a component of Drosophila polar granules. Development 103, 625-40.

Henley, J. and Poo, M. M. (2004). Guiding neuronal growth cones using Ca2+ signals. Trends Cell Biol 14, 320-30.

Horvay, K., Claussen, M., Katzer, M., Landgrebe, J. and Pieler, T. (2006). Xenopus Dead end mRNA is a localized maternal determinant that serves a conserved function in germ cell development. Developmental Biology.

Houston, D. and King, M. (2000). Germ plasm and molecular determinants of germ cell fate. Current Topics in Developmental Biology 50, 155-81.

Jacob, S. T., Sajdel, E. M. and Munro, H. N. (1970). Specific action of alphaamanitin on mammalian RNA polymerase protein. Nature 225, 60-2.

Jaglarz, M. K. and Howard, K. R. (1994). Primordial germ cell migration in Drosophila melanogaster is controlled by somatic tissue. Development 120, 83-9.

Jaglarz, M. K. and Howard, K. R. (1995). The active migration of Drosophila primordial germ cells. Development 121, 3495-503.

Jenkins, A. B., McCaffery, J. M. and Van Doren, M. (2003). Drosophila Ecadherin is essential for proper germ cell-soma interaction during gonad morphogenesis. Development 130, 4417-26.

Jowett, T. and Lettice, L. (1994). Whole-mount in situ hybridizations on zebrafish embryos using a mixture of digoxigenin- and fluorescein-labelled probes. Trends in Genetics 10, 73-4.

Kamm, K. E. and Stull, J. T. (2001). Dedicated myosin light chain kinases with diverse cellular functions. Journal of Biological Chemistry 276, 4527-30.

Kane, D. A., Hammerschmidt, M., Mullins, M. C., Maischein, H. M., Brand, M., van Eeden, F. J., Furutani-Seiki, M., Granato, M., Haffter, P., Heisenberg, C. P. et al. (1996). The zebrafish epiboly mutants. Development 123, 47-55. 
Katoh, K., Kano, Y., Amano, M., Onishi, H., Kaibuchi, K. and Fujiwara, K. (2001). Rho-kinase--mediated contraction of isolated stress fibers. Journal of Cell Biology 153, 569-84.

Kawano, Y., Fukata, Y., Oshiro, N., Amano, M., Nakamura, T., Ito, M., Matsumura, F., Inagaki, M. and Kaibuchi, K. (1999). Phosphorylation of myosinbinding subunit (MBS) of myosin phosphatase by Rho-kinase in vivo. Journal of Cell Biology 147, 1023-38.

Kimmel, C., Ballard, W., SR, K., B, U. and TF, S. (1995). Stages of embryonic development of the zebrafish. Developmental Dynamics 203, 253-310.

Klemke, R. L., Cai, S., Giannini, A. L., Gallagher, P. J., de Lanerolle, P. and Cheresh, D. A. (1997). Regulation of cell motility by mitogen-activated protein kinase. Journal of Cell Biology 137, 481-92.

Knaut, H., Pelegri, F., Bohmann, K., Schwarz, H. and Nusslein-Volhard, C. (2000). Zebrafish vasa RNA but not its protein is a component of the germ plasm and segregates asymmetrically before germline specification. Journal of Cell Biology 149, $875-88$.

Knaut, H., Steinbeisser, H., Schwarz, H. and Nusslein-Volhard, C. (2002). An Evolutionary Conserved Region in the vasa 3'UTR Targets RNA Translation to the Germ Cells in the Zebrafish. Current Biology 12, 454-66.

Knaut, H., Werz, C., Geisler, R. and Nusslein-Volhard, C. (2003). A zebrafish homologue of the chemokine receptor Cxcr4 is a germ-cell guidance receptor. Nature 421, 279-82.

Kopfstein, L. and Christofori, G. (2006). Metastasis: cell-autonomous mechanisms versus contributions by the tumor microenvironment. Cellular and Molecular Life Sciences.

Krøvel, A. V. and Olsen, L. C. (2002). Expression of a vas:EGFP transgene in primordial germ cells of the zebrafish. Mechanisms of Development 116, 141-50.

Kucia, M., Jankowski, K., Reca, R., Wysoczynski, M., Bandura, L., Allendorf, D. J., Zhang, J., Ratajczak, J. and Ratajczak, M. Z. (2004). CXCR4-SDF-1 signalling, locomotion, chemotaxis and adhesion. J Mol Histol 35, 233-45.

Kunwar, P. S., Starz-Gaiano, M., Bainton, R. J., Heberlein, U. and Lehmann, R. (2003). Tre1, a G Protein-Coupled Receptor, Directs Transepithelial Migration of Drosophila Germ Cells. PLoS Biol 1, E80.

Kuo, J. C., Wang, W. J., Yao, C. C., Wu, P. R. and Chen, R. H. (2006). The tumor suppressor DAPK inhibits cell motility by blocking the integrin-mediated polarity pathway. Journal of Cell Biology 172, 619-31.

Kuwana, T., Maeda-Suga, H. and Fujimoto, T. (1986). Attraction of chick primordial germ cells by gonadal anlage in vitro. Anatomical Record 215, 403-6. 
Kuwana, T. and Rogulska, T. (1999). Migratory mechanisms of chick primordial germ cells toward gonadal anlage. Cell Mol Biol (Noisy-le-grand) 45, 725-36.

Köprunner, M., Thisse, C., Thisse, B. and Raz, E. (2001). A zebrafish nanosrelated gene is essential for the development of primordial germ cells. Genes and Development 15, 2877-85.

Lasko, P. and Ashburner, M. (1988). The product of the Drosophila gene vasa is very similar to eukaryotic initiation factor-4A. Nature 335, 611-617.

Lehmann, R. and Nusslein-Volhard, C. (1991). The maternal gene nanos has a central role in posterior pattern formation of the Drosophila embryo. Development 112, 679-91.

Li, Q., Shirabe, K., Thisse, C., Thisse, B., Okamoto, H., Masai, I. and Kuwada, J. Y. (2005). Chemokine signaling guides axons within the retina in zebrafish. Journal of Neuroscience 25, 1711-7.

Liou, J., Kim, M. L., Heo, W. D., Jones, J. T., Myers, J. W., Ferrell, J. E., Jr. and Meyer, T. (2005). STIM is a $\mathrm{Ca} 2+$ sensor essential for $\mathrm{Ca} 2+$-store-depletiontriggered Ca2+ influx. Current Biology 15, 1235-41.

Lu, Q., Sun, E. E., Klein, R. S. and Flanagan, J. G. (2001). Ephrin-B reverse signaling is mediated by a novel PDZ-RGS protein and selectively inhibits G proteincoupled chemoattraction. Cell 105, 69-79.

Manji, S. S., Parker, N. J., Williams, R. T., van Stekelenburg, L., Pearson, R. B., Dziadek, M. and Smith, P. J. (2000). STIM1: a novel phosphoprotein located at the cell surface. Biochimica et Biophysica Acta 1481, 147-55.

Matsui, Y., Zsebo, K. and Hogan, B. (1990). Embryonic expression of a haematopoietic growth factor encoded by the S1 locus and the ligand for c-kit. Nature 347, 667-669.

McLaren, A. (1999). Signaling for germ cells. Genes and Development 13, 373-6.

Molyneaux, K. and Wylie, C. (2004). Primordial germ cell migration. International Journal of Developmental Biology 48, 537-43.

Molyneaux, K., Zinszner, H., Kunwar, P., Schaible, K., Stebler, J., Sunshine, M., O'Brien, W., Raz, E., Littman, D., Wylie, C. et al. (2003). The chemokine SDF1/CXCL12 and its receptor CXCR4 regulate mouse germ cell migration and survival. Development 130, 4279-4286.

Montell, D. J. (2003). Border-cell migration: the race is on. Nat Rev Mol Cell Biol 4, 13-24.

Montero, J. A. and Heisenberg, C. P. (2004). Gastrulation dynamics: cells move into focus. Trends Cell Biol 14, 620-7. 
Naora, H. and Montell, D. J. (2005). Ovarian cancer metastasis: integrating insights from disparate model organisms. Nat Rev Cancer 5, 355-66.

Nguyen, D. H., Catling, A. D., Webb, D. J., Sankovic, M., Walker, L. A., Somlyo, A. V., Weber, M. J. and Gonias, S. L. (1999). Myosin light chain kinase functions downstream of Ras/ERK to promote migration of urokinase-type plasminogen activator-stimulated cells in an integrin-selective manner. Journal of Cell Biology 146, 149-64.

Nieto, M. A. (2001). The early steps of neural crest development. Mechanisms of Development 105, 27-35.

Niewiadomska, P., Godt, D. and Tepass, U. (1999). DE-Cadherin is required for intercellular motility during Drosophila oogenesis. Journal of Cell Biology 144, 53347.

Niewkoop, P. D. and Sutasurya, L. A. (1979). Primordial germ cells in the chordates. In Cambridge University Press, pp. 118-123.

Ohinata, Y., Payer, B., O'Carroll, D., Ancelin, K., Ono, Y., Sano, M., Barton, S. C., Obukhanych, T., Nussenzweig, M., Tarakhovsky, A. et al. (2005). Blimp1 is a critical determinant of the germ cell lineage in mice. Nature.

Oppermann, M. (2004). Chemokine receptor CCR5: insights into structure, function, and regulation. Cellular Signalling 16, 1201-10.

Oritani, K. and Kincade, P. W. (1996). Identification of stromal cell products that interact with pre-B cells. Journal of Cell Biology 134, 771-82.

Parent, C. (2004). Making all the right moves: chemotaxis in neutrophils and Dictyostelium. Current Opinion in Cell Biology 16, 4-13.

Petit, I., Szyper-Kravitz, M., Nagler, A., Lahav, M., Peled, A., Habler, L., Ponomaryov, T., Taichman, R. S., Arenzana-Seisdedos, F., Fujii, N. et al. (2002). G-CSF induces stem cell mobilization by decreasing bone marrow SDF-1 and upregulating CXCR4. Nat Immunol 17, 17.

Pujol, F., Kitabgi, P. and Boudin, H. (2005). The chemokine SDF-1 differentially regulates axonal elongation and branching in hippocampal neurons. Journal of Cell Science 118, 1071-80.

Raz, E. (2003). Primordial germ-cell development: the zebrafish perspective. Nature Reviews Genetics 4, 690-700.

Raz, E. (2004). Guidance of primordial germ cell migration. Current Opinion in Cell Biology 16, 169-73.

Reichman-Fried, M., Minina, S. and Raz, E. (2004). Autonomous Modes of Behavior in Primordial Germ Cell Migration. Developmental Cell 6, 589-596. 
Rhyner, J. A., Durussel, I., Cox, J. A., Ilg, E. C., Schafer, B. W. and Heizmann, C. W. (1996). Human recombinant alpha-parvalbumin and nine mutants with individually inactivated calcium- and magnesium-binding sites: biochemical and immunological properties. Biochimica et Biophysica Acta 1313, 179-86.

Riento, K., Guasch, R. M., Garg, R., Jin, B. and Ridley, A. J. (2003). RhoE binds to ROCK I and inhibits downstream signaling. Molecular and Cellular Biology 23, 4219-29.

Roland, J., Murphy, B. J., Ahr, B., Robert-Hebmann, V., Delauzun, V., Nye, K. E., Devaux, C. and Biard-Piechaczyk, M. (2003). Role of the intracellular domains of CXCR4 in SDF-1-mediated signaling. Blood 101, 399-406.

Roos, J., DiGregorio, P. J., Yeromin, A. V., Ohlsen, K., Lioudyno, M., Zhang, S., Safrina, O., Kozak, J. A., Wagner, S. L., Cahalan, M. D. et al. (2005). STIM1, an essential and conserved component of store-operated Ca2+ channel function. Journal of Cell Biology 169, 435-45.

Rørth, P. (2002). Initiating and guiding migration: lessons from border cells. Trends Cell Biol 12, 325-31.

Sabbioni, S., Barbanti-Brodano, G., Croce, C. M. and Negrini, M. (1997). GOK: a gene at $11 \mathrm{p} 15$ involved in rhabdomyosarcoma and rhabdoid tumor development. Cancer Research 57, 4493-7.

Saitou, M., Barton, S. C. and Surani, M. A. (2002). A molecular programme for the specification of germ cell fate in mice. Nature 418, 293-300.

Santos, A. C. and Lehmann, R. (2004). Germ cell specification and migration in Drosophila and beyond. Current Biology 14, R578-89.

Saraste, M., Sibbald, P. R. and Wittinghofer, A. (1990). The P-loop--a common motif in ATP- and GTP-binding proteins. Trends in Biochemical Sciences 15, 430-4.

Savagner, P. (2001). Leaving the neighborhood: molecular mechanisms involved during epithelial-mesenchymal transition. BioEssays 23, 912-23.

Schaloske, R. H., Lusche, D. F., Bezares-Roder, K., Happle, K., Malchow, D. and Schlatterer, C. (2005). Ca2+ regulation in the absence of the iplA gene product in Dictyostelium discoideum. BMC Cell Biol 6, 13.

Schejter, E. D. and Wieschaus, E. (1993). Functional elements of the cytoskeleton in the early Drosophila embryo. Annual Review of Cell Biology 9, 67-99.

Schmidt, J. T., Morgan, P., Dowell, N. and Leu, B. (2002). Myosin light chain phosphorylation and growth cone motility. Journal of Neurobiology 52, 175-88.

Seydoux, G. (1996). Mechanisms of translational control in early development. Current Opinion in Genetics and Development 6, 555-61. 
Seydoux, G. and Fire, A. (1994). Soma-germline asymmetry in the distributions of embryonic RNAs in Caenorhabditis elegans. Development 120, 2823-34.

Shohat, G., Shani, G., Eisenstein, M. and Kimchi, A. (2002). The DAP-kinase family of proteins: study of a novel group of calcium-regulated death-promoting kinases. Biochimica et Biophysica Acta 1600, 45-50.

Silver, D. L. and Montell, D. J. (2001). Paracrine signaling through the JAK/STAT pathway activates invasive behavior of ovarian epithelial cells in Drosophila. Cell 107, 831-41.

Sjaastad, M. D. and Nelson, W. J. (1997). Integrin-mediated calcium signaling and regulation of cell adhesion by intracellular calcium. BioEssays 19, 47-55.

Somlyo, A. P. and Somlyo, A. V. (2003). Ca2+ sensitivity of smooth muscle and nonmuscle myosin II: modulated by $\mathrm{G}$ proteins, kinases, and myosin phosphatase. Physiological Reviews 83, 1325-58.

Somlyo, A. V., Bradshaw, D., Ramos, S., Murphy, C., Myers, C. E. and Somlyo, A. P. (2000). Rho-kinase inhibitor retards migration and in vivo dissemination of human prostate cancer cells. Biochemical and Biophysical Research Communications 269, 652-9.

Sonnemann, J., Aichem, A. and Schlatterer, C. (1998). Dissection of the cAMP induced cytosolic calcium response in Dictyostelium discoideum: the role of cAMP receptor subtypes and G protein subunits. FEBS Letters 436, 271-6.

Starz-Gaiano, M., Cho, N. K., Forbes, A. and Lehmann, R. (2001). Spatially restricted activity of a Drosophila lipid phosphatase guides migrating germ cells. Development 128, 983-91.

Starz-Gaiano, M. and Lehmann, R. (2001). Moving towards the next generation. Mechanisms of Development 105, 5-18.

Starz-Gaiano, M. and Montell, D. J. (2004). Genes that drive invasion and migration in Drosophila. Current Opinion in Genetics and Development 14, 86-91.

Stebler, J., Spieler, D., Slanchev, K., Molyneaux, K. A., Richter, U., Cojocaru, V., Tarabykin, V., Wylie, C., Kessel, M. and Raz, E. (2004). Primordial germ cell migration in the chick and mouse embryo: the role of the chemokine SDF-1/CXCL12. Developmental Biology 272, 351-61.

Tanaka, S. S. and Matsui, Y. (2002). Developmentally regulated expression of mil-1 and mil-2, mouse interferon-induced transmembrane protein like genes, during formation and differentiation of primordial germ cells. Mechanisms of Development 119 Suppl 1, S261-7.

Tanaka, S. S., Yamaguchi, Y. L., Tsoi, B., Lickert, H. and Tam, P. P. (2005). IFITM/Mil/fragilis family proteins IFITM1 and IFITM3 play distinct roles in mouse primordial germ cell homing and repulsion. Dev Cell 9, 745-56. 
Tepass, U. (1999). Genetic analysis of cadherin function in animal morphogenesis. Current Opinion in Cell Biology 11, 540-8.

Thermes, V., Grabher, C., Ristoratore, F., Bourrat, F., Choulika, A., Wittbrodt, J. and Joly, J. S. (2002). I-SceI meganuclease mediates highly efficient transgenesis in fish. Mechanisms of Development 118, 91-8.

Thiery, J. P. (2002). Epithelial-mesenchymal transitions in tumour progression. Nat Rev Cancer 2, 442-54.

Thiery, J. P. (2003). Cell adhesion in development: a complex signaling network. Current Opinion in Genetics and Development 13, 365-71.

Thiery, J. P. and Sleeman, J. P. (2006). Complex networks orchestrate epithelialmesenchymal transitions. Nat Rev Mol Cell Biol 7, 131-42.

Thisse, B., Pflumio, S., Fürthauer, M., Loppin, B., Heyer, V., Degrave, A., Woehl, R., Lux, A., Steffan, T., Charbonnier, X. Q. et al. (2001). Expression of the zebrafish genome during embryogenesis (NIH R01 RR15402). ZFIN Direct Data Submission. http://zfin.org/cgi-bin/webdriver? MIval=aa-pubview2.apg\&OID=ZDBPUB-010810-1.

Tian, W., Laffafian, I., Dewitt, S. and Hallett, M. B. (2003). Exclusion of exogenous phosphatidylinositol-3,4,5-trisphosphate from neutrophil-polarizing pseudopodia: stabilization of the uropod and cell polarity. EMBO Rep 4, 982-8.

Totsukawa, G., Wu, Y., Sasaki, Y., Hartshorne, D. J., Yamakita, Y., Yamashiro, S. and Matsumura, F. (2004). Distinct roles of MLCK and ROCK in the regulation of membrane protrusions and focal adhesion dynamics during cell migration of fibroblasts. Journal of Cell Biology 164, 427-39.

Totsukawa, G., Yamakita, Y., Yamashiro, S., Hartshorne, D. J., Sasaki, Y. and Matsumura, F. (2000). Distinct roles of ROCK (Rho-kinase) and MLCK in spatial regulation of MLC phosphorylation for assembly of stress fibers and focal adhesions in 3 T3 fibroblasts. Journal of Cell Biology 150, 797-806.

Tsuda, M., Sasaoka, Y., Kiso, M., Abe, K., Haraguchi, S., Kobayashi, S. and Saga, Y. (2003). Conserved role of nanos proteins in germ cell development. Science 301, 1239-41.

Tsunekawa, N., Naito, M., Sakai, Y., Nishida, T. and Noce, T. (2000). Isolation of chicken vasa homolog gene and tracing the origin of primordial germ cells. Development 127, 2741-50.

Unterweger, N. and Schlatterer, C. (1995). Introduction of calcium buffers into the cytosol of Dictyostelium discoideum amoebae alters cell morphology and inhibits chemotaxis. Cell Calcium 17, 97-110. 
Van Doren, M., Broihier, H. T., Moore, L. A. and Lehmann, R. (1998). HMGCoA reductase guides migrating primordial germ cells [see comments]. Nature 396, 466-9.

Vicente-Manzanares, M., Cabrero, J. R., Rey, M., Perez-Martinez, M., Ursa, A., Itoh, K. and Sanchez-Madrid, F. (2002). A role for the Rho-p160 Rho coiled-coil kinase axis in the chemokine stromal cell-derived factor-1alpha-induced lymphocyte actomyosin and microtubular organization and chemotaxis. Journal of Immunology 168, 400-10.

Vicente-Manzanares, M., Montoya, M. C., Mellado, M., Frade, J. M., del Pozo, M. A., Nieto, M., de Landazuri, M. O., Martinez, A. C. and Sanchez-Madrid, F. (1998). The chemokine SDF-1alpha triggers a chemotactic response and induces cell polarization in human B lymphocytes. European Journal of Immunology 28, 2197207.

Vila-Coro, A. J., Rodriguez-Frade, J. M., Martin De Ana, A., Moreno-Ortiz, M. C., Martinez, A. C. and Mellado, M. (1999). The chemokine SDF-1alpha triggers CXCR4 receptor dimerization and activates the JAK/STAT pathway. FASEB Journal 13, 1699-710.

Wadgaonkar, R., Nurmukhambetova, S., Zaiman, A. L. and Garcia, J. G. (2003). Mutation analysis of the non-muscle myosin light chain kinase (MLCK) deletion constructs on CV1 fibroblast contractile activity and proliferation. Journal of Cellular Biochemistry 88, 623-34.

Wang, C. and Lehmann, R. (1991). Nanos is the localized posterior determinant in Drosophila [published erratum appears in Cell 1992 Mar 20;68(6):1177]. Cell 66, 637-47.

Wang, W., Goswami, S., Lapidus, K., Wells, A. L., Wyckoff, J. B., Sahai, E., Singer, R. H., Segall, J. E. and Condeelis, J. S. (2004). Identification and testing of a gene expression signature of invasive carcinoma cells within primary mammary tumors. Cancer Research 64, 8585-94.

Webb, D. J., Donais, K., Whitmore, L. A., Thomas, S. M., Turner, C. E., Parsons, J. T. and Horwitz, A. F. (2004). FAK-Src signalling through paxillin, ERK and MLCK regulates adhesion disassembly. Nat Cell Biol 6, 154-61.

Weidinger, G., Stebler, J., Slanchev, K., Dumstrei, K., Wise, C., Lovell-Badge, R., Thisse, C., Thisse, B. and Raz, E. (2003). dead end, a novel vertebrate germ plasm component, is required for zebrafish primordial germ cell migration and survival. Current Biology 13, 1429-1434.

Weidinger, G., Wolke, U., Koprunner, M., Klinger, M. and Raz, E. (1999). Identification of tissues and patterning events required for distinct steps in early migration of zebrafish primordial germ cells. Development 126, 5295-307. 
Weidinger, G., Wolke, U., Koprunner, M., Thisse, C., Thisse, B. and Raz, E. (2002). Regulation of zebrafish primordial germ cell migration by attraction towards an intermediate target. Development 129, 25-36.

Wessels, D., Soll, D. R., Knecht, D., Loomis, W. F., De Lozanne, A. and Spudich, J. (1988). Cell motility and chemotaxis in Dictyostelium amebae lacking myosin heavy chain. Developmental Biology 128, 164-77.

Westerfield, M. (1995). The Zebrafish Book. Oregon: University of Oregon Press. Wheelock, M. J. and Johnson, K. R. (2003). Cadherins as modulators of cellular phenotype. Annu Rev Cell Dev Biol 19, 207-35.

Williams, R. T., Manji, S. S., Parker, N. J., Hancock, M. S., Van Stekelenburg, L., Eid, J. P., Senior, P. V., Kazenwadel, J. S., Shandala, T., Saint, R. et al. (2001). Identification and characterization of the STIM (stromal interaction molecule) gene family: coding for a novel class of transmembrane proteins. Biochemical Journal 357, 673-85.

Wolke, U., Weidinger, G., Köprunner, M. and Raz, E. (2002). Multiple levels of post-transcriptional control lead to germ line specific gene expression in the zebrafish. Current Biology 12, 289-294.

Wyckoff, J. B., Jones, J. G., Condeelis, J. S. and Segall, J. E. (2000). A critical step in metastasis: in vivo analysis of intravasation at the primary tumor. Cancer Research 60, 2504-11.

Wylie, C. (1999). Germ cells. Cell 96, 165-74.

Xiang, Y., Li, Y., Zhang, Z., Cui, K., Wang, S., Yuan, X. B., Wu, C. P., Poo, M. M. and Duan, S. (2002). Nerve growth cone guidance mediated by G protein coupled receptors. Nat Neurosci 5, 843-8.

Yamada, A., Hirose, K., Hashimoto, A. and Iino, M. (2005). Real-time imaging of myosin II regulatory light-chain phosphorylation using a new protein biosensor. Biochemical Journal 385, 589-94.

Yoon, C., Kawakami, K. and Hopkins, N. (1997). Zebrafish vasa homologue RNA is localized to the cleavage planes of 2- and 4-cell-stage embryos and is expressed in the primordial germ cells. Development 124, 3157-65.

Youngren, K. K., Coveney, D., Peng, X., Bhattacharya, C., Schmidt, L. S., Nickerson, M. L., Lamb, B. T., Deng, J. M., Behringer, R. R., Capel, B. et al. (2005). The Ter mutation in the dead end gene causes germ cell loss and testicular germ cell tumours. Nature 435, 360-4.

Yumura, S., Furuya, K. and Takeuchi, I. (1996). Intracellular free calcium responses during chemotaxis of Dictyostelium cells. Journal of Cell Science 109 (Pt 11), 2673-8. 
Zhang, N., Zhang, J., Purcell, K. J., Cheng, Y. and Howard, K. (1997). The Drosophila protein Wunen repels migrating germ cells. Nature 385, 64-7.

Zhang, S. L., Yu, Y., Roos, J., Kozak, J. A., Deerinck, T. J., Ellisman, M. H., Stauderman, K. A. and Cahalan, M. D. (2005). STIM1 is a Ca2+ sensor that activates CRAC channels and migrates from the $\mathrm{Ca} 2+$ store to the plasma membrane. Nature 437, 902-5.

Zhu, Y., Yu, T., Zhang, X. C., Nagasawa, T., Wu, J. Y. and Rao, Y. (2002). Role of the chemokine SDF-1 as the meningeal attractant for embryonic cerebellar neurons. Nat Neurosci 5, 719-20. 


\section{Acknowledgements}

I would like to thank especially Erez Raz who faithfully supported my work and ideas that allowed me to grow into the world of science. I am glad about the time I could benefit from his broad experience and professional perception, moreover I highly appreciated his prolific advices, which will accompany and shape my scientific future wherever it will decide to drag me.

I am grateful to Michael Kessel and Wolfgang Engel for the helpful guidance and discussions during the committee meetings, as well a special thanks to Steffen Burkhardt for all his attempts in organizing and planning every days progress of the program.

Besides I would like to express gratitude to all former and current lab members for the friendly, happy and lively atmosphere during the past few years; especially Jürg who accompanied my way as a friend for so many years, Markus with whom I spent quite some hours in the Spanish classes, the group of Sonia, Natalia, Elena, Maria, Krasimir and Bijan with whom I spent my coffee brakes including some interesting conversations. At this point I would like to thank Karin for the kind encouragement during difficult times and for being the generous person she is. Many thanks to Michal for the fruitful collaboration, the critical and obliging comments about work and manuscripts, and for her concerns about my daily and nightly ride home with the bicycle. I am very thankful to Julia, Rebecca and Helene who helped me with all their enthusiasm and energy even experiments often did not work straight away.

I would also like to thank my friends back home; Sandro, Mevio, Christoph, Thomas $\mathrm{H}$, Jenny and Jovita for a great and fun time during our studies, parties and holidays. Before I moved to Göttingen, I was working at the University in Zurich and retrospectively this was a very important time in terms of in which direction my future would go. During that time I have met wonderful people who became more than just colleagues, therefore I would like the thank Graziella, Safia, Maja, Renjie, Igor, Ghislaine and Ralph for the happy time.

At this point I would like to express my gratitude to my friends Tiemo, Jochen and Nadia who went with me together through a difficult and stressful time of education moreover I would like to say thanks for the pleasant time we have spent together next to studying. Special thanks to Tabrez - you have been a brilliant study-team-mate. 
Nicht zuletzt möchte ich den wichtigsten Menschen in meinem Leben danken. Für all die Liebe, das Vertrauen und die Unterstützung werde ich meinen Eltern für immer dankbar sein. Sie haben mich durch gute und weniger gute Zeiten stets begleitet und haben dadurch einen großen Anteil daran, wo ich heute im Leben stehe - Danke für alles! Außerdem danke ich meinen Geschwistern, Simone und Damian, für die Liebe und Freundschaft die uns verbindet und zusammenhält.

Finalmente, estoy agradecido y muy feliz de haber ganado con Katya una nueva familia mexicana, tan maravillosa y adorable. Mi amor, quiero darte las gracias por el enorme apoyo que me entregaste durante tiempos buenos y difíciles. Te doy las gracias por adorarme, y quiero que sepas que llegué a ser el hombre que soy solo por tu amor. ¡Te quiero! 


\section{List of publications}

Blaser, H., Eisenbeiss, S., Neumann, M., Reichman-Fried, M., Thisse, B., Thisse, C. and Raz, E. (2005). Transition from non-motile behaviour to directed migration during early PGC development in zebrafish. Journal of Cell Science 118, 4027-38. 


\section{Curriculum Vitae}

\section{PERSONAL INFORMATION}

Citizen: Switzerland

Date of birth: 16.02.1976

Marital status: married

Place of birth: Winterthur (Switzerland)

\section{EDUCATION}

2002 - 2006 Max Planck Institute for Biophysical Chemistry, Dept. Germ Cell Development, Göttingen

(Germany)

Doctoral Thesis

2001 - 2002 Int. Max Planck Research School, University of Göttingen (Germany)

Graduation with grade $A$ in the Int. MasterPhD Program

$2000 \quad$ University of Maastricht (Netherlands)

(University of Professional Education $\mathrm{HBO}$ )

Graduation as BSc. in Chemistry

1996 - 1999 Zurich University of Applied Sciences Winterthur, (Switzerland)

Graduation as Chemist HTL

1993 - 1996 Ciba AG (Novartis) Basel, (Switzerland) Graduation of the "Technical Professional Maturity" and Apprenticeship as laboratory Assistant 